\title{
سلطة الإدارة ( صاصبة المناقصة ) فى تعديل العقود الإدارية وحق المتعاقد معها فى توفير الضمانات المالية له
}

\author{
(.).وا فؤاو نصر (اللّ عوض)

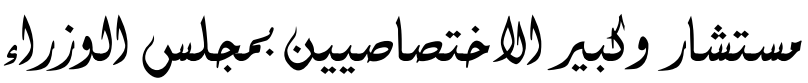 \\ لجنة (لمناقصات (لمركزية الذوريتى)
}




\section{سلطة الإدارة (صاحبة المناقصة) في تعديل العقود}

\section{الإدارية وحق المتعاقد هعها في توفير الضهانات المالية له}

\section{ملخص الار اسة :}

يهرف هذا البحث الماتل بيان حقوق سلطة الإدارة فـي تعـديل العقـود الإدارية بأر ادتها المنفردة وهو حق للإدارة ومشروع قانوناً وحق أصبل مـستمد في صفتها كسلطة عامة على الرغم بأن هذه السلطة ليست مطلقة من كل قيــد، في المقابل ذلك إعطاء حق للمتعاقد الآخر في توفيره للضمانات المادية الكافيــة و استحقاقه للتفويض سواءً أكان هذا التفويض كلياً أو جزئياً وفقاً لمبادئ التوازن المالي وفعل الأمير و الظروف الطارئة و القوة القاهرة.

ومن الأصول التي تقدم عليها تعاقد الجهة الإدارية مع الأفر اد و الهيئـات، أن يخضع هذا التعاقد لاعتبار ات تتعلق بالمر افق الفنية و المالية ولها حق تعـديل العقود الإدارية بإر ادتها المنفردة و التي تعتبر في السلطات المعترف بها قانونــاً ومن الفقهاء الإداريين على الرغم من اختلاف مذاهبهم حول ذلك التعديل، وفـي المقابل يتمتع الملتزم الآخر للتعاقد في عقود التز ام الموفق العام بحقوق محــددة و أهمها حقه في التعويض بجزئية الكلي و الجزئي بحسب حجم الخسارة أو وقوع الضرر عليه في جر اء ذلك التعديل في من قبل سلطة الإدارة و المقابل المــادي المنصوص عليه في العقد وحصوله على التسهيلات و المز ايا المقررة له. 


\section{هقدهة}

تخضع العقود كأصل عام للمبدأ القائل بأن العقد شريعة المتعاقدين فــن

المسلم به في مجال القانون الخاص أن هذا المبدأ يعني سيادة مبدأ القوة الملزمـــة للعقد بين أطر افه، فالعقد بالنسبة إلى عاقديه يعتبر بمثابة القانون أو بمعنى أصح هو قانون خاص بهما و إن كان منشؤه الاتفاق بينهما.

ويترتب على كون العقد بمثابة القانون بالنسبة لأطر افه أنه لا يجـوز لأي

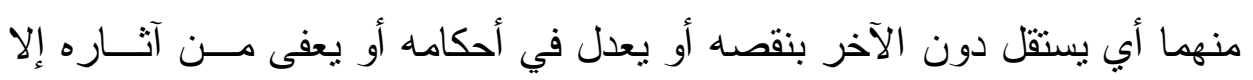
في حدود ما يسمح به الاتفاق أو يقضي به قانون و هذا ما نصت عليــه المــادة

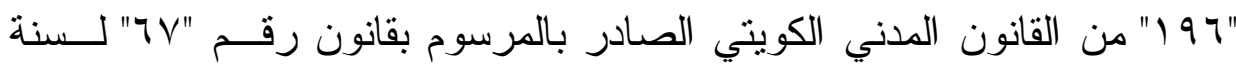

و هذا الخطاب موجه ليس فقط للمتعاقدين و إنما إلــى المـشر ع الـــي لا

يستطيع من حيث المبدأ تعديل العقد وكذلك القاضي الذي يجب عليه فــي حالـــة

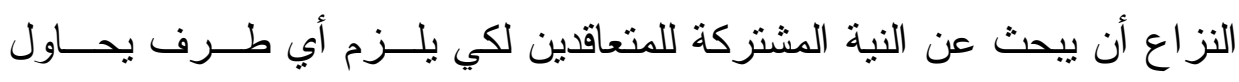

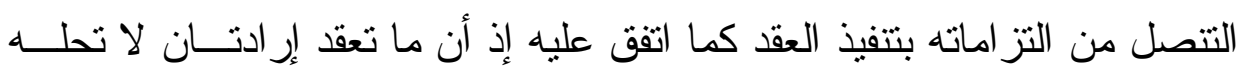

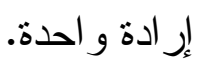

rVA مجلة البحوث القانونيتوالإقتصاديت 
و المفروض أن تخضع العقود الإدارية لما تخضع لله سائر العقــود مــن

أحكام، ذلك أن الإدارة بتعاقدها مع الغير قد التزمت تجاه المتعاقد معها بمتل مــــا التزم به هذا الأخير تجاهها وذلك باحتر امها لما تعهدت به تجاهه أو لـبس مــن

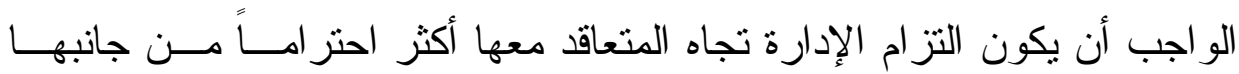
خاصة وأن هذا الأمر هو الذي حدى بالمتعاقد مع الإدارة إلى إيــر ام العقــد؟ ألا تعتبر محاولة الإدارة التحلل من وعودها لهذا الأخير نوع مــن المـشروع فـي

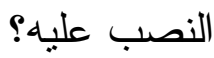

ومع ذللك فإنه يجب الاعتر اف، حسب ما يؤكده فقهاء القانون العام، بــأن

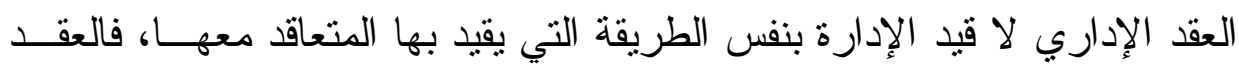
الإداري لا يتمتع في مواجهة الإدارة بقوة العقد الملزمة التي تكون للعقود المدنية بين الأفر اد، بل يقيم ر ابطة مرنة بين الإدارة و المتعاقد معهــا بحيـــث أن الإدارة تستطيع أن تعدل بإر ادتها المنفردة التز امات هذا الأخير زيادة أو نقصسا ليس هــذا فحسب بل لها أن تتحلل منه نهائيا وذلك بإنهائها إذا اقتضى الصالح العام ذلك. فالر أي الغالب في الفقه يرى أن سلطة الإدارة في تعــديل العقـد الإداري بإر ادتها المنفردة ذو أساس قانوني و إنما لا يجد أساساً في العقد ذاته و إنما يستتد إلى امتياز تعاقدي تمليه اعتبار ات ذات أهمية قصوى خار ج العقد هي ما تـسمى الإدارة إلى تحقيقه ألا وهو سير المر افق العامة بانتظام و اطر اد خدمة للمـصحلة 
العامة لا تستطيع الإدارة التخلي عنها أو التقريط في أي حسال مــن الأحـــال، و عليه فإن هذه السلطة تجد أساسها فيما تتطلبه مقتضيات سير المر افـق العامــة

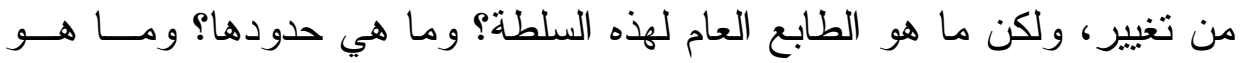

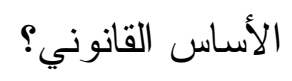

فالإدارة لها حق التعديل و المتعاقد الآخر له حق التعــويض مـــــام هـــو

ملتزم كل الالتز ام بتتفيذ كافة شروطوبنود العقد المتفق عليه الطرفان المتعاقدان عن كل الأضر ار و الخسائر التي لحقت به جر اء ذلك على أساس مبدأ التـــوازن المالي للعقد وتطبيق مبدأ نظرية فعل الأمير.

\section{أهبية البحث:}

يتجلى البحث إلى بيان ماللإدارة تملكها على خلاف القو اعد العامة الحـق

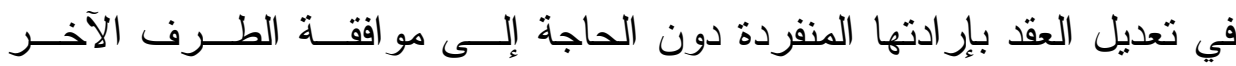
ويكون تعديل العقد بالإدارة القديمة مدفوعة بالتعديل بمقتضيات المصلحة العامة

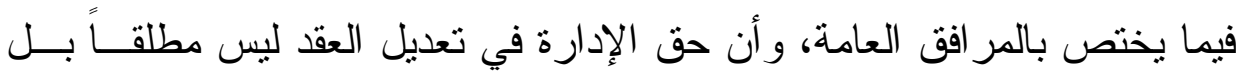

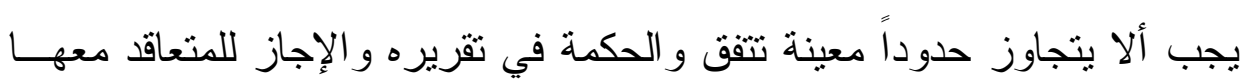
طلب الفسخ فيجب أو لاً ألا تصل الإدارة صاحبة السلطة فـي اســتخدامها لهـــا الحق في تعديل نوع الحق إلى تعديل نوع العقد أو موضوعه بأن تطلــب الإدارة

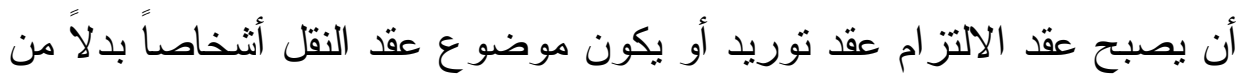

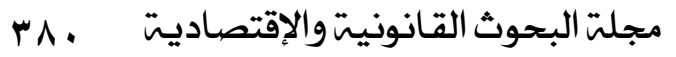


البضائع، ثانيا: التعديل يجب ألا يتتاول حقوق المتعاقدين الماليــة وأن يقتـ ضـى

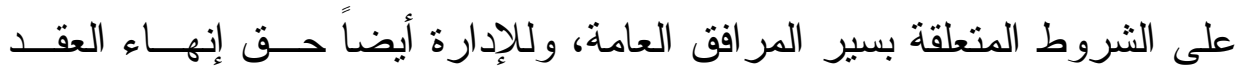
بإر ادتها المنفردة دون أي خطأ من جانب المتعاقد الآخر و لا يلزم الــنص عـن

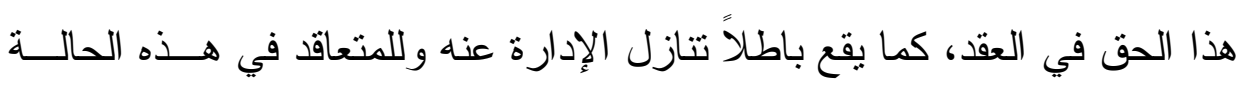
الحق في التعويض الكامل عما فاته من كسب وما لحق به من خـسارة بـسبب إنهاء العقد، وير اعى في الحق المخول للإدارة ليس مطلقا بل مشروط بـشرطين الأول أن تقتضي الصالح العام أو صالح المرفق إنهاء العقد و الثاني أن تتــوافر لقرار التعديل أو الإنهاء كافة الثروط اللازمــة لمـشروعية الأعمــال المبنــــة

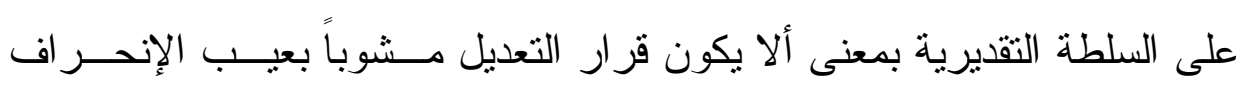
بالسلطة.

وتقتصر هذه الحالة دور القاضي التحقيق عن ممارسة للإدارة لأي تعسف

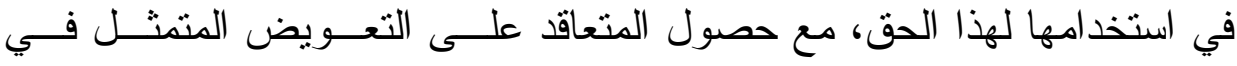
حصوله على المقابل المادي المتفق عليه في العقد مع الجهة الإدارية وفي المــــة المحدة، كما يجوز للمتعاقد الحصول على دفعة مقدمة بشروط محسددة وعـدم التأخير في صرف هذه المستحقات بالإضـافة إلى مسئولية الإدارة عن الأخطــاء

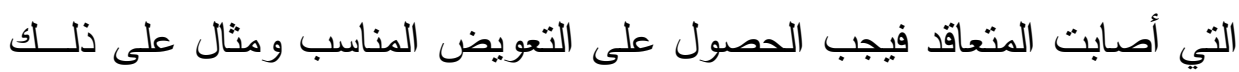
تسليم الموقع وتعديل العقد بنسب كبيرة.

مجلت البحوث القانونيت والإقتصاديت 
أ.د / فؤاد نصر اللَه عوض

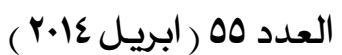

وتزتيباً ما تقدم سنقسم دراستتا في هذا البحث الذي بستتد إلـى خطة قسمت إلى ثلاثنة مباحث هي:

المبثث الأول: الأساس القانوني ونطاق السلطة الإدارية صاحبة المناقصة فـي تعديل العقد الإداري بإر ادتها المنفردة.

المبحث الثاني: نطاق سلطة الإدارة صاحبة المناقصة في تعديل شــروط العقـــ الإداري بإر ادتها المنفقردة.

المبحث الثالث: الضمانات المتوفرة للمتعاقدين في سلطة الإدارة بعــد إعطائهــا الحق في سلطة تعديل العقد الإداري بإر ادتها المنفردة. 


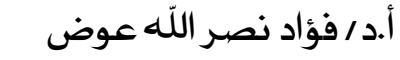

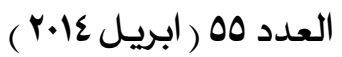 \\ المبحث الأول \\ الأساس القانوني ونطاق السلطة الإدارية صاحبة المناقصة \\ في تعديل العقد الإداري بإرادتها المنفردة}

إضفاء الطابع أو الصفة القانونية التي تـستتد عليــه الــلطة الإداريــة لصاحبة المناقصة أو المشرف عليه تعتبر أساسية وضرورية في تعديلها للعقـود

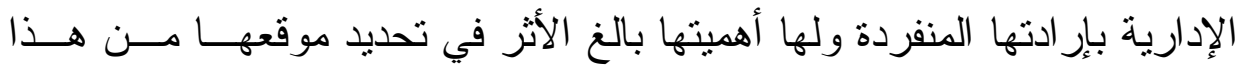
العمل، و على الرغم بأن هنالك محل خلاف و اضح بين الفقهاء في هذا التــصرف من قبل الإدارة الحكومية حول سلطة هذه الإدارة من تعديل شروط العقد المبرم مع الطرف الثاني وهو المناقص الفائز بالترسية و أهم ملاحظات و الخلافات فـي الرأي بين الفقهاء حول تعديل السلطة الإدارية للعقد وهي:

( الإدارة تستمد سلطتها في تعديل العقد بإر ادتها المنفردة من خارج الر ابطة العقدية بين الطرفان المتعاقدان و التي تتصف بسلطة إلإدارية عليا ولهــا نفوذ و اسع في هذا الثنأن.

r سلطة مشتركة أي أن السلطة تستمد قوتها وسلطاتها من الر ابطة العقديــة نفسها أب بين الإدارة صاحبة التعاقد وبين المتعاقد معها. 
r) من الصعوبة بمكان إثبات فكرة المرفق العام (') بقـــد إنثـباع حاجــة عامة لاى الجمهور و الذي يعتبر فيه اتصـال العقد بنشاط المرفق منفــرداً وفقاً للقضـاء الفرنسي أو مجتمعاً شرط اتباع الإدارة صــاحبة المناقـــة لوسائل القانون العام وذلك وفقاً للقانون المصري، بأنها لا تكون الأســاس القانوني لسلطة الإدارة في تعديل عقودها بإر ادتها المنفردة ولكنـــهـ مـن السهل من الناحية الأخرى بإثبات عدم جدو اها و أهميتها. §) تغيير الظروف كأساس دمجها لسلطة التعديل لا يعني تغييــر متطلبــات العمل بتغييره أو تعديله سو اء بالزيادة أو النقصان في إثــــر افها للمر افــق العامة بصور ها المختلفة بتعدد أغر اضها باعتبار ها ظاهرة تصاحب تتفيــذ

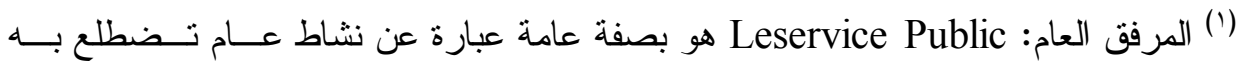

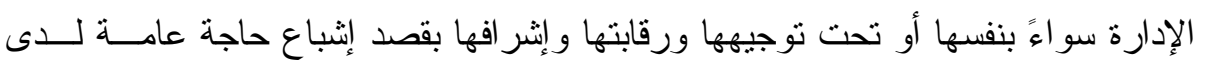

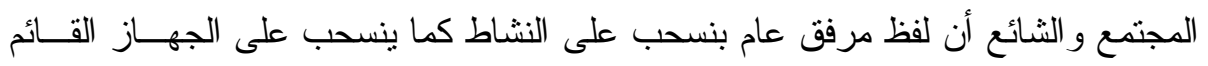

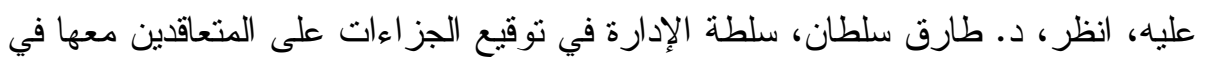

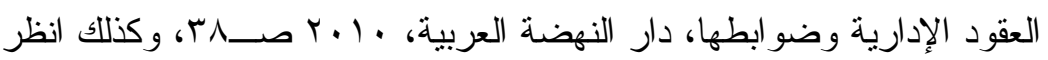

A. De Lubadere, Traité de Droit Administratif, OP, Cit P604 وكنلك انظر ، عبد العزيز عبد المنعم خليفة، الأسس العامة للعقود الإدارية، منشأة المعارف

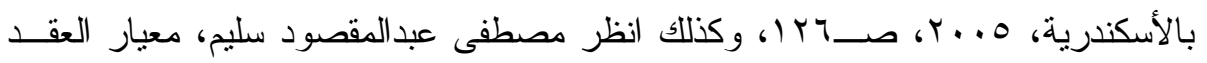

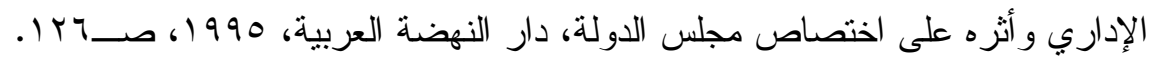

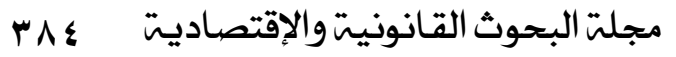


جميع الأعمال وليست قاصرة على تتفيذ العقد الإداري، ولهذا فهي حجــة غير مقنعة علاوة أن القضاء الإداري لم يأخذ لها.

0) سلطة الإدارة صاحبة المناقصة في عملية تعديل العقد تـستصد قوتهــا (') وسلطتها التقديرية الو اسعة كسلطة عامة آمرة وليست كطرف في العقــد و هذا الر أي مردود عليه باعنبار أن السلطة الإدارية غير مطلقة من غير قيود بما في ذللك العقد نفسه و الذي ينص عليه شروط العقد المبــرم مـــع المناقص (الطرف الآخر) و الذي فيه عدم تتازل الإدارة الحكوميـــة فيهـــا حتى في عقودها الخاصة ويجب على القاضي أن بصدر أحكامسهـ وفقــاً لطبيعة كل من طرف التعاقد.

7) ومن الحجج الأخرى التي ييديها الفقهاء وهي أن سلطة الإدارة في تعديل العقد بإر ادتها المنفردة على أساس منطلبات سير المر افق العامة وبالتـالي

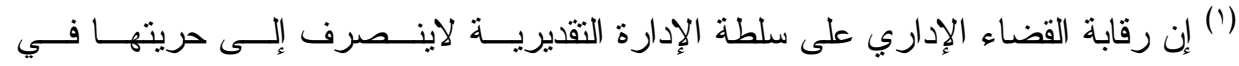

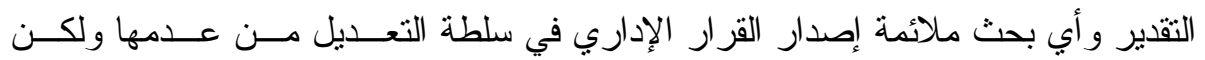

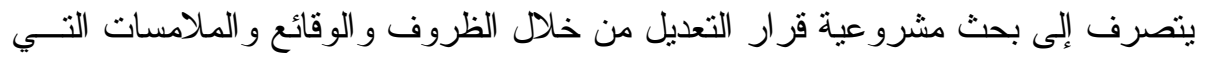
صاحبت إصداره وذلك للتحقيق من مطابقتها للقانون من عدمها، انظر حكم محكمة التمييز

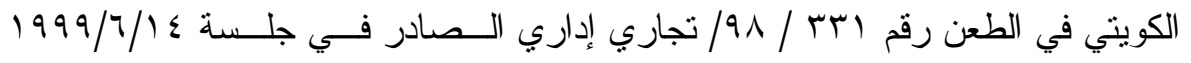

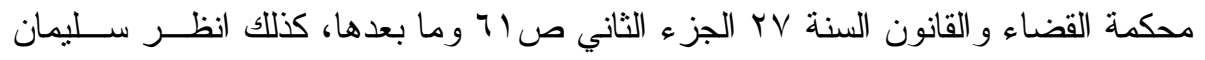

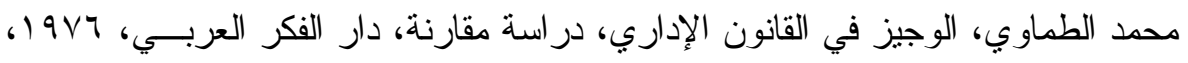

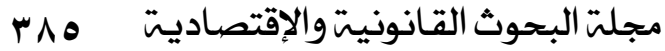


يحقق الصالح العام للمجتمع، ولكن بعض الفقهاء تصدو الهذه الحجة وذللك بالقول حتى ينسلم صحتها إلا أنها بمنطق الأمور لا يحــول دون إثبــات

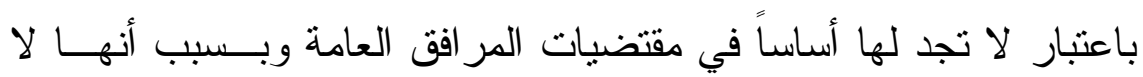
تؤدي إلى نتائج مميزة في جميع الظروف و الأحو ال لفكرة المر افق العامة وخاصة بأن القضاء الإداري و القضاء العادي لم يؤسـس ســلطة الإدارة وتعديل العقد للمر افق العامة ككل يخضع للقضاء سواءً القـضـاء الإداري أو القضاء العادي وبصفة خاصة إذا كانت هذه التعديلات تجاوز نقديرات الطرفين عند إير ام العقد أو التي لا تتجاوز إطلاقاً القو اعد التـي حـددها

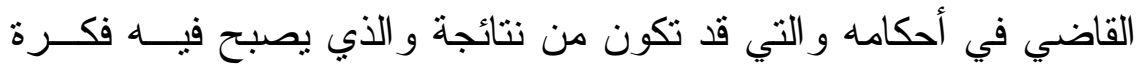
المر افق العامة غير صالحة أو نافعة كأساس لسلطة الإدارة في التعـديل بنود شروط العقد.

( و هناك آر اء أخرى بين الفقهاء وهي محل خلاف، فقد غالى أحسدهم فـي

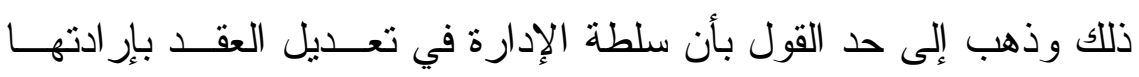

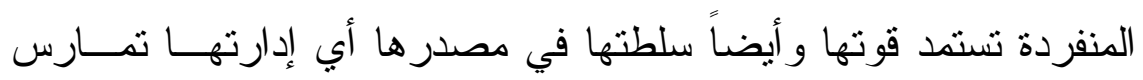

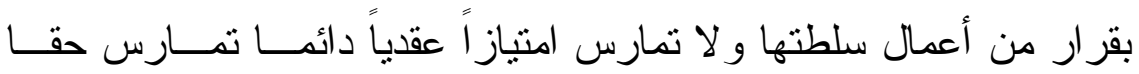
تملكه باعتبار ها سلطة عامة تملك سلطة تقديرية منحها المـشر ع وهــا الحق يعتبر من النظام العام و الذي يكفلها القانون، وهذا يعنـي أن بنـــود 
شروط العقد المبرم مع الطرف الثاني التي تتناول حق الإدارة في التعديل لا توجد و إنما مجرد تذكير ها بوجوده دون أن يؤثر في طابعـهـ القــانوني و المركز القانوني أو طابعه المميز.

وعلى ضوء ذللك نرى أن سلطة الإدارة صاحبة المناقصة في تعديل العقد

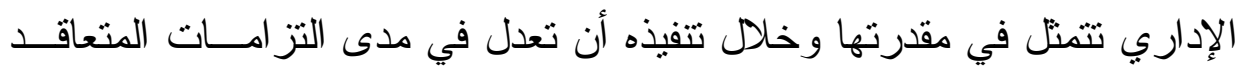
معها و هو المناقص الفائز في المناقصة بالزيادة أو النقصـان بإر ادتهـــا المنفــردة حسب مقتضيات المصلحة العامة و الذي يقتضي الأمر بعدم وجود قيود أو موانع أو مدى عدم اعتر اضه من قبل الفقه إذا ما نص عليه في العقد أو دوره في نص قانوني أو لائحي لددى علاقة العقد المبرم بالمر افق العامــة باعتبــاره معيـار للاختصاص الإداري، و الدق أن القضـاء لم يألو جهداً في ســبيل التوفيـق بــين

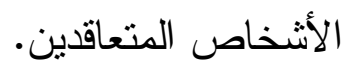

اختلف الر أي حول الأساس القانوني لسلطة الإدارة في تعـديل عقودهـــا الإدارية، فذهب جانب من الفقه إلى تأسيس هذا الحق على أساس فكرة الــسلطة العامة، وذهب جانب آخر إلى فكرة الر ابطـــة التعاقديــة القائــــة بـين الإدارة و المتعاقد، و هذا ما سنوضحه في بحثنا هذا. 


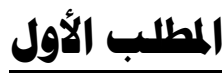

\section{التكيـف القانوني لسطبة الإدارة}

\section{صاحبة المناقصة لتعديل العقد بإرادتها المنفردة}

القوة الملزمة لشروط قيود العقد المبرم بــين الجهــة الإداريـــة صــاحبة

المناقصة وبين المقاول و المناقص الفائز بترسيه المناقصة باعنباره أقل الأســعار

ومتطابقاً مع شروط العامة و الخاصة ومتطلبات المو اصــفات الخاضـــة العامـــة للمناقصة و لا يكاد يختلف من هذه النواحي للعقدين القانوني الخــاص و القــانون العام في هذا المجال ولا يتعارض قانونياً مع شروط العقد وهي تمنل قوة ملزمة ووصو لاً للالتز ام ببنوده، و لا يمكن للسلطة الإدارية إذا ورد النص فـي تعـديل العقد إذا كان في صلب هذا العقد باعتبار أن الإدارة تستتد في ممارستها لها على النصوص الو اردة في العقد المبرم بين الطرفين. ولكن السؤ ال الذي يطر ح نفسه هنا، في حالة عدم وجود هــذا الـــص أو عندما يغفل العقد النص على حق الإدارة في تعديل بنود شروط العقد هل يجــوز لها الحق للجهة الإدارية صاحب التعاقد للمناقصة أن تجري أي تعــديل تتطلبــــ المصلحة العامة بالر غم من خلوه من النص عليه؟ هذا ما أثتـار الخــلاف بـين 
مختلف الفقهاء بين المؤيد و المعارض من وجوده أو عدم وجوده، علــى الــرغم لهذا الخلاف الفقهي الذي لم يعد له وجود اليوم إلا أنه قد لعب دوراً إيجابياً فـي رسم الحدود لسلطة التعديل من جانب و احد من المؤكد وللمــصلحة العامــة أن

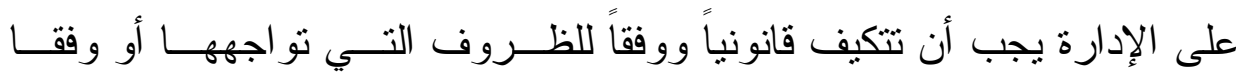
للمستجدات التي قد تطر أ على العقد مع وجه الخــصوص مـــع التقــدم التقنــي و التكنولوجي الدقيق لحق الإدارة في التعديل وفقــا تحقيقــهـ المــصلحة العامـــة للمر افق العامة ووفقاُ بما يتو افق مع التطور ات الجارية باعتبــار هــذه الـسلطة للتعديل ليست عامة وليست تقديرية باعتبار ها مقيــدة ومنظمـــة وتقــاس بمــدى حصول المتعاقد الآخر على حق التعويض (') مع حق سلطة التعـديل الإداري، ولكل هذا سوف نقوم بدر اسة أهم هذه الآر اء للفقهاء حول مدى سلطة الإدارة في تعديل العقد وذللك وفقا للمحاور التالية:

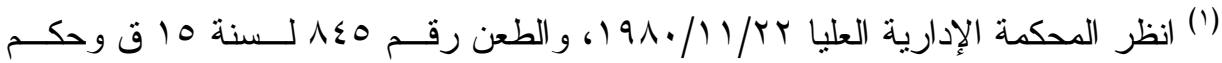

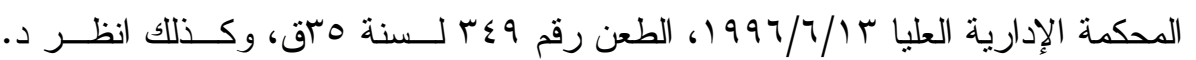
محمد حلمي العقد الإداري. دار الفكر العربي، دار النهضة، صــهـ، وكذلك انظر محمد

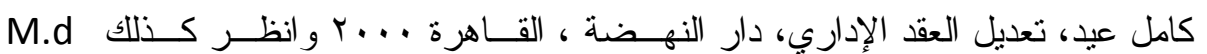
Villiers, Droit Public general, litec, 2003 P. 675 et 648. George (J) Theories General decontrats Administratifs, J.UR. Calss, Paris, P.7 


\section{المحور الأول: الآر اء المؤيدة حول سلطة الإدارة في تعديل العقد}

اتفق معظم الفقهاء في أدائهم أكثر شيو عاً وقدماً فــي هـــا الخـصوص بوجود حق الكامل للإدارة صاحبة النعاقد في تعديل العقد الإداري المبــرم مــع المتعاقد الآخر وذلك بما تتمتع هذه الإدارة بقوة القانون حتـى بــدون أي نــص ينص في حقها في التعديل، وليس في حقها أن تتتازل بأي شروط أو بنـــــــن شروط العقد المتفق فيه الطرف فيه بموجب بند الوجوب و القبــول بــهـ يتعــق بالنظام العام وحتى في حقها في تعديل العقد أثناء تتفيذ بنود وشروط العقـــ أي قبل تتفيذ العقد وبالتالي تعديل التز امات المتعاقد الآخر معها أي المناقص الفـائز بعقد المناقصة، و الذي أصبح فيه طابعاً مميز اً لــسلطة الإدارة وتعـديل العقــود بإر ادتها المنفردة (')

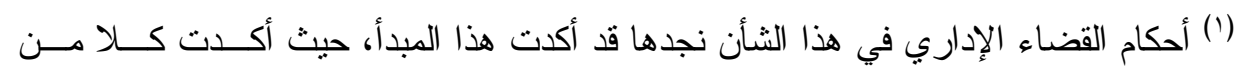

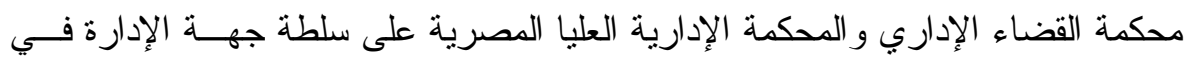

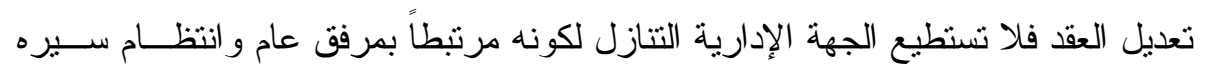

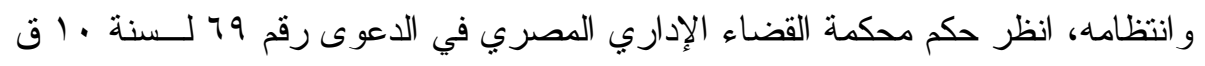

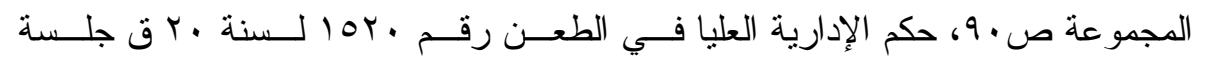

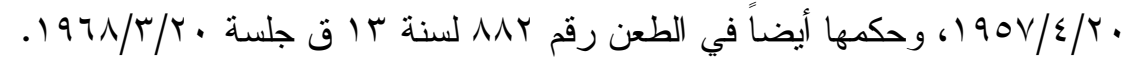

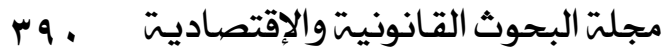




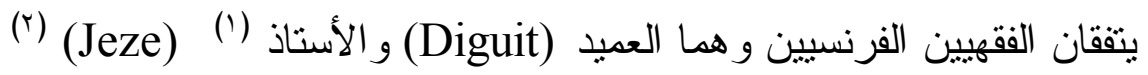
بأن سلطة الإدارة في تعديل العقد بإر ادتها الانفر ادية يتوقف عند أنو اع خاصـــة

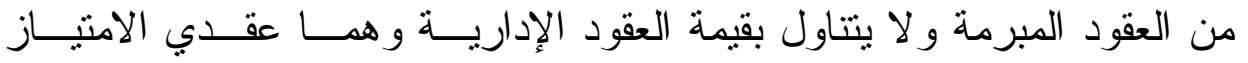
و الأشغال العامة، حيث أن موقف الأستاذ (جيز) يرى جانب الأطر اف وذللك لأنه

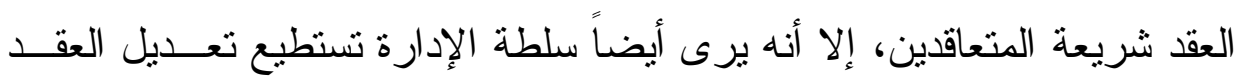

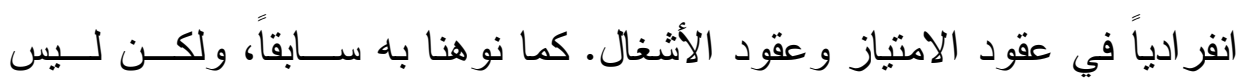
بالأستاذ إلى وجود سلطة عقدية تسمح لهم بمثل هذا التعديل الإنفر ادي، و إنما إلى الطبيعة الخاصة لهذين السلطة تتظيمية تخولها منل هذا الحق.

وبعد ذلك أقرت الغالبية الساحقة من الفقه الفرنسي حق التعـديل كسلطة أصيلة تتمتع بها الإدارة بغض النظر عن وجود نــصوص قانونيــة عقديـــة أو تشريعية تيحها، وكسلطة عامة تبانرها الإدارة في جميع العقود دون تخصيص

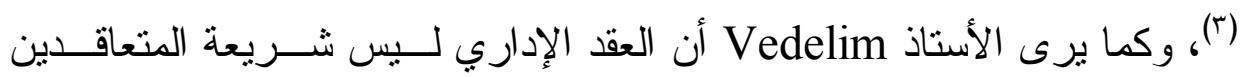

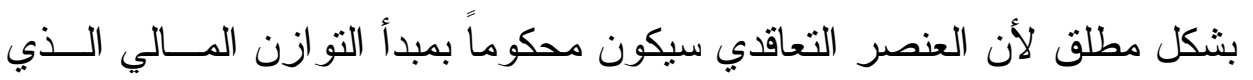

Duguit. L. Traité de droitconstitutionnel . t. Paris, 1927, ed3 P. انظـر (')

Jeze G. les princepes Generaux de Droit Administratif, B.I.P Paris, انظر (r) 1939. P. 486. (r) انظر ، عمر حلمي، سلطة الإدارة في تعديل العقد الإداري، دار النهضة العربية، القــاهرة 
يقضي نوعاً من التغييرية مـــع اســتمر ار التــوازن فـــ حقـوق و التزامــات الأطر اف (') و هذا ما يحق له مختلفاً عن العقد المدني الذي يحــد فيـــه حقــوق

$$
\text { و التز امات الأطر اف بصورة نهائية (؟). }
$$

\section{المحور الثاني: الآراء المنكرة حول سلطة الإدارة في تعديل العقد}

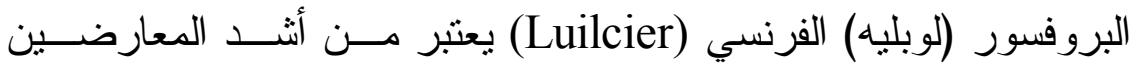
و الر افضين بشكل قاطع لسلطة الإدارة في تعديل العقد الإداري بإرادتها المنفردة و الذي يدعي فيه بعدم وجود منل هذه السلطة ومن يدعي بوجودها بأنه اعتقــاد خاطئ في تاريخ القانون العام الفرنسي، أما الحجم التي استتد عليها في تبريــره لعدم وجود هذه السلطة الإدارية و أهمها بأن القضاء الإداري الفرنسي قد أنكــر على الإدارة سلطة تعديل العقد المبرم مع الطرف الثاني وفقاً لإر ادتها المنفــردة (r) وذلك وفقا للمعطبات التالية.

أولاً: هناك اعتقاد خاطئ ابتدعها بعض الفقهاء الفرنسيين و الذين يــؤدون بسلطة الإدارة في تعديل العقد الإداري المبرم مع الطرف الآخر في العقد وذلك

Vedelm. Cours de Dorit Aministratif, 1953, 1130. انظر (1)

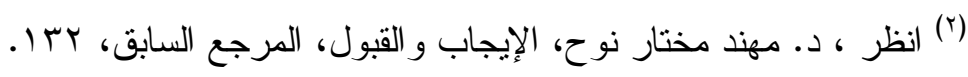

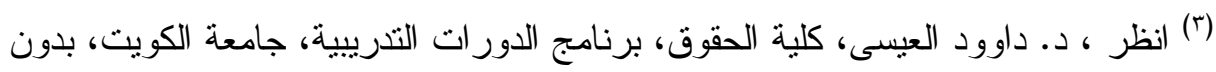
ذكر السنة، صــ وما دوا بعدها.

مجلتَ البحوث القانونيتوالإقتصاديت 
وفقاً لإر ادتها المنفردة، وذلك باعتبار أن الإدارة نستمد قوتها و السلطة التقديريــة التي تتمتع بها و التي منحها المشرع به وحتى بدون نص ينص على ذلك و التـي

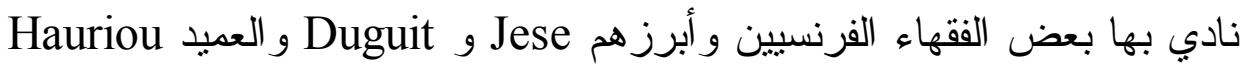
(') وذلك باعتبار أن الخصوصية التي يجب أن توفــق بـين العنــصر الإداري

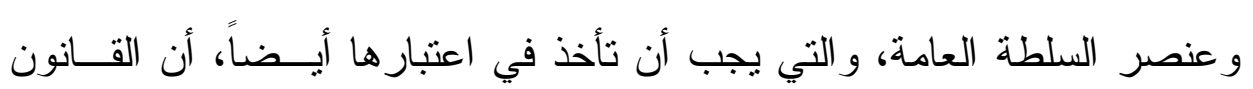
العام لا يعرف مبدأ سلطان الإدارة، وأن شرعية التصرفات الإدارية إنما تتجسد من خلال المبدأ القائل بأن السلطة الإدارية لا تكون حره في تكوين إرادتها بــل على العكس فإن هذه الإدارة تكون أسيرة قاعدة التوجيه حتى معنـى المـصلحة

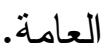

ثانياً: وكما اعتمد و أنكره الأستاذ (لوبليه) الفرنسي أيضـاً والــذي أضــاف حجة أخرى لا تقل أهمية عن الحجة الأولى و التي أدلى بها، وذلك بالقول حسب

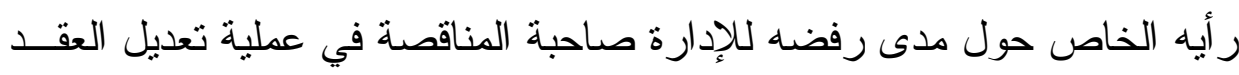

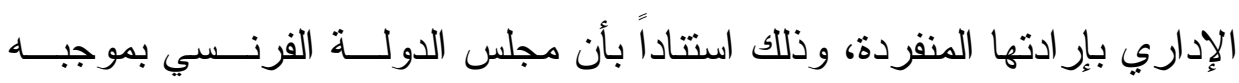

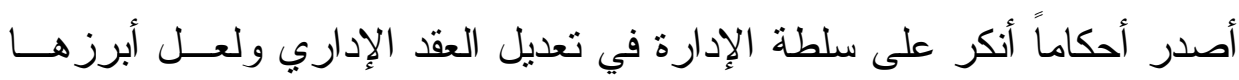

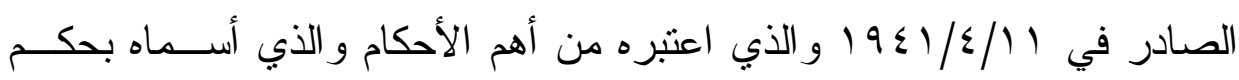
Hauriou, m. La Juispurdence Administrative, Paris 1929, P25 etc، انظـــ (') وكنلك انظر ، Pouyaud. D. La Nullite des coutvats Administratifs L. G.D.I Paris, 1991, P66 
المبدأ الر افض بسلطة التعديل للعقد (')، بحيث أن حيثيات الحكم الـذي أصــدره مجلس الدولة الفرنسي في هذا الثأن تدل دلالة واضحة في حرمسـان ورفـضه القاطع في حق الإدارة صاحبة التعاقد في تعديل بنود وشروط العقد المبرم بينهــا وبين المتعاقد معها وبصفة خاصة عقدي الامتياز ومر افق عامة و الذي يؤكد فيه احتر ام الجهة الإدارية و الملتزم بها الطرفان المتعاقدان بشروط وبنود العقـــــلا

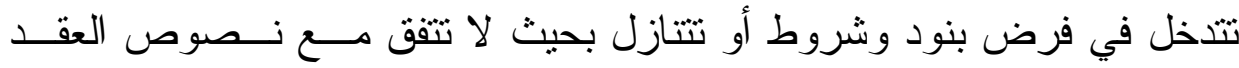
المنقق عليه الطرفان عند إبر ام العقد، على الرغم ما تضمنه الإدارة من العقـود

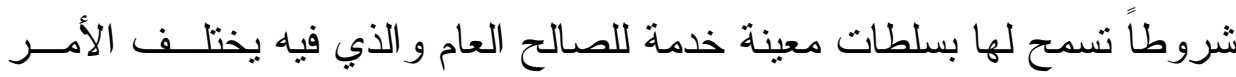
و الذي لا تجده في القانون الخاص و إنما ييقى دائماً بأن عقود القانون العام كعقود

(1) مبدأ هذا الحكم الذي أصدره مجلس الدولة الفرنسي في /1/ / 19 ومقتضاه بأن الإدارة

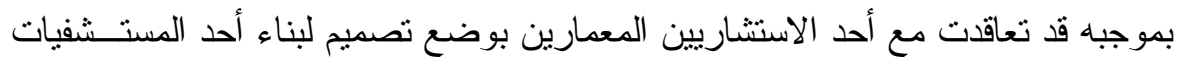

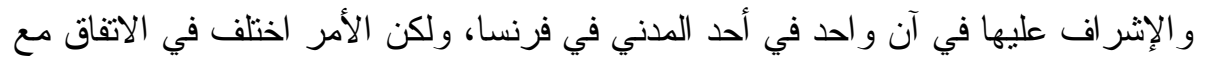
الجهة الإدارية بحثت أثناء التتفيذ اضطر المهندس إلى الإقامة في مدينة أخرى تحيد المكان

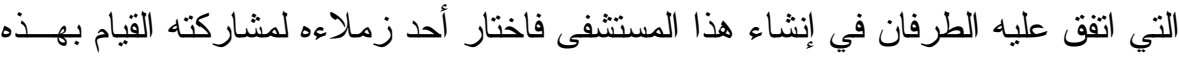

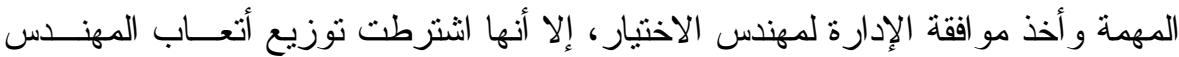

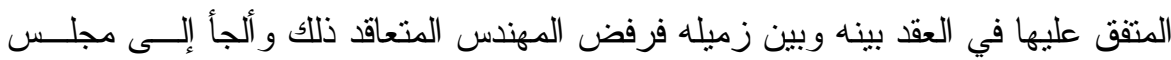

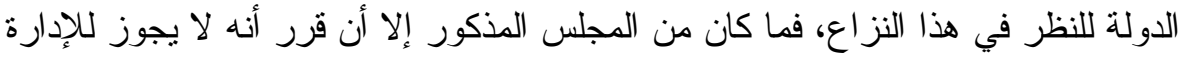

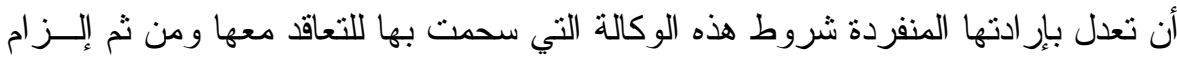
إدارة المستثفى بأداء جميع الأتعاب محل العقد للمهندس المتعاقد. 
وشرطعة للمتعاقدين (')، ولكن الأمر لا يختلف للأستاذ (Bénoi) (r) عن الأستاذ (لوبليه) الر افض وله من الآر اء المنكرة لمتل هذه السلطة و التي ليس لها الحـق في تعديل العقد وفقاً لإر ادتها المنفردة وينقا الآخــربين بـشـدة المؤيــدة لــسلطة الإدارة في تعديل العقد الإداري وذللك وفقاً للحجج التي ينادي بها وأهمها:

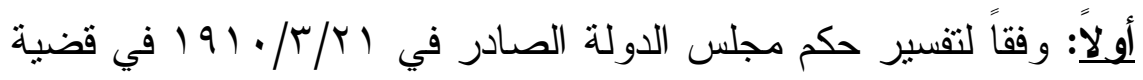

شر اكة القطار ات الفرنسية عندما الزمت هذه الثريحة بتعـديل مواعيــد سـير القطار ات فعلت ذلك استتاداً إلى سلطة الضبط الإداري وذلك حفظا للنظام العسام التي بستند عليها القانون وليس سلطة الإدارة في تعديل العقد الإداري بإرادتهــا

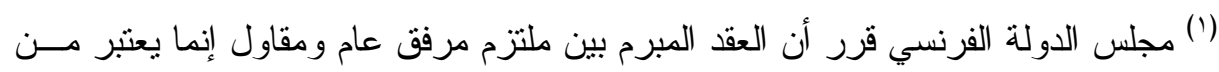

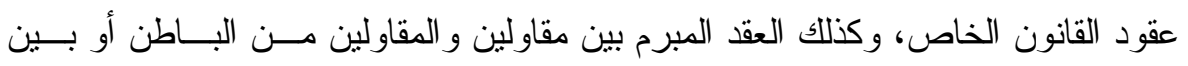

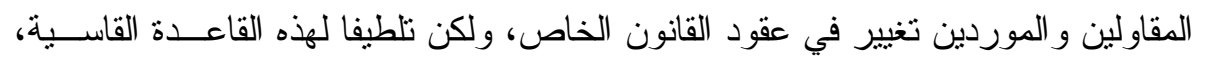

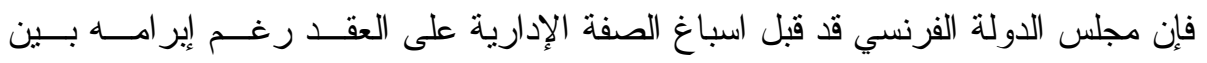

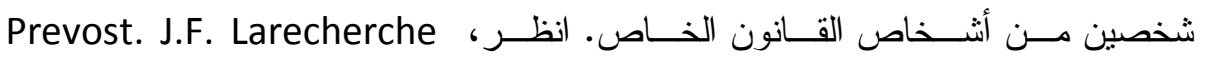
ducritiere du contrat Administratif, R.D.P. paris, 1971, P. 891. انظر د. مصطفى سليم، الوكالة في إبرام العقد الإداري، دار النهضية العربيــة، القـاهرة،

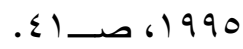

Benoit. P. Le Droit Administratif Franceis, Dalloz, Paris, 1968, P ، انظر (r) .685 .

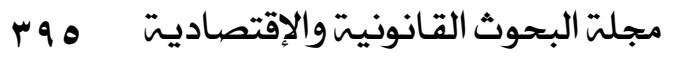


المنفردة باعتبار ها طرفاً في العقد و استعطلت اختصاصها كسلطة فقط في ضــبط

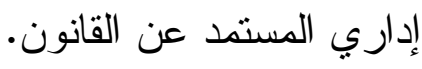

ثانياً: بعتقد (Benoit) في رأيه حول سلطة الإدارة فـي تعـديل العقـد

الإداري بإر ادتها المنفردة بأن تللك الإدارة تستطيع إنهاء العقد بــصورة طفيفــة فإنها في نفس الوقت لا تستطيع أن تدخل عليه أي تعديل للاختلاف الواضح بين سلطة الإنهاء وسلطة التعديل، وذلك لأن إنهاء العقد بصورة غير نهائيـــة إنــــا بصورة ميسرة معترف به للإدارة فهي التي تقدر ضرورة الاستمر ار فيسهـ مـن عدمه في مقابل تعويض الطرف الاخر عن هذا الإنهاء المتضمن لكل التزاماتــه أو بعضها حسب احتياجات المرفق العام ورعاية للمال العام في حين أن التعديل

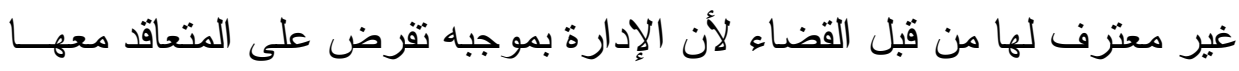
التزامات تختلف عن ما اتفق عليها في العقد أو أنها تطالبه بالقيام بأعمال أخرى لم يكن على استعداد للقيام بها لأسباب فنية أو مالية، هذه الاعتبــار ات الو اقعيــة هي التي جعلت سلطة التعديل غير مقبولة من حيــث الو اقــع و لا مــن حيــث القانون (')

(') انظر ، د. داوود العيسى، كلية الحقوق قسم القانون العام، جامعة الكويت، بدون تذكر سنة

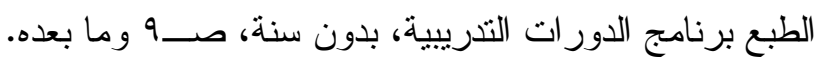

مجلة البحوث القانونيت والإقتصاديت و ب 
المحور الثالث: الآراء الر افضة الموجهة للمعارضبن لسلطة الإدارة في تعديل

\section{العقد الإداري بإرادتها المنفردة}

هناك بعض الفقهاء الفرنسيين و غير هم وبصفة خاصة الذين يبدون آر اؤهم الر افضة و الموجهة مباثرة للمعارضين لسلطة الإدارة في تعديل العقــــ الإداري بإر ادتها المنفردة وفي مقدمتهم الأستاذ (Laubadere) و الذي ابدى فيــه بعـض

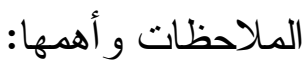
أولاً: يجب أن بستتد حكم مجلـس الدولــة الفرنـسي الــصادر بتـــاريخ

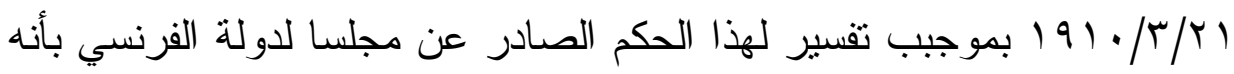
اعتر اف للإدارة صاحبة القرار في تعـديل العقــــ الإداري بموجـب إرادتهــا الإنفر ادية وذلك بعكس الحكم الصادر في بr// / 19 19 من قبل مجلس الدولـــة الفرنسي و الذي يستتد عليه بعض الفقهاء المعارضين لسلطة الإدارة في تعـديل العقد الإداري بإر ادتها المنفردة، و الذي بموجبه رفض الاعتر اف بسلطة إدخــال أي تعديل مهما كان نوعه على شروط وبنود العقد مع أن ظــروف كـلـ مــن الحكمين الذين أصدر اه مجلس الدولة الفرنسي واحدة. مما يؤكد ذلك أن مجلس الدولة الفرنسي قد وقف موققين من قضية واحدة لعلى ألا وهي إن ما رفضه المجلس في عملية تعـديل العقــــ الإداري للــسلطة

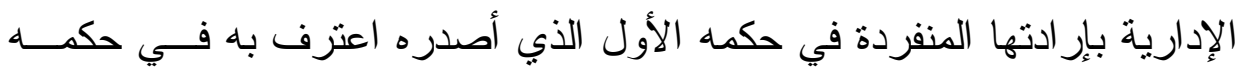


الثاني بعد سبع سنو ات من تاريخ إصدار حكمه الثاني الذي اعترف فيــه بحـق سلطة الإدارة القيام بتعديلات على شروط العقـــ بعـــــ إبر امــهـ مــع الطــرف

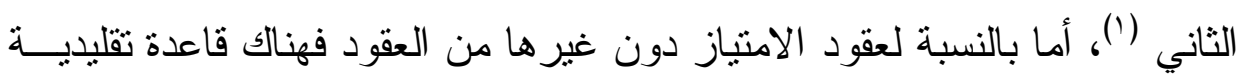

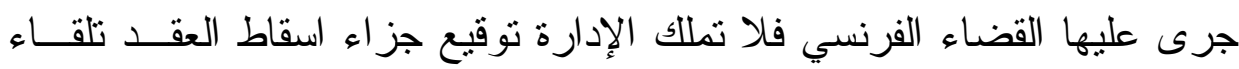

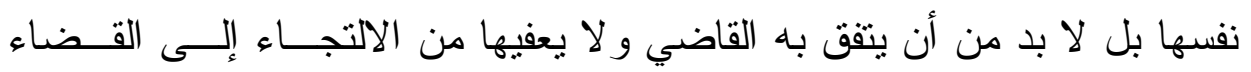
للحصول على حكم بإسقاط الالتز ام إلا في صريح في العقد أو في دفتر الثروط وفي هذه الحالة يستطيع القاضي إلغاء القرار الصادر من الإدارة بإسقاط الالتز ام إذا شابه عيب من العيوب بالإضـافة إلى الحكم بالتعويض عما يلحـق بــه مـن أضر ار بسبب هذا القرار المعيب (r).

Laubadére, A. Dupouvoir de L'administratoin d'imposer Unilatera ، انظر (') Lements des changement aux dispositions des contrats .Administratifs, R.D. P,1954, P. 50.

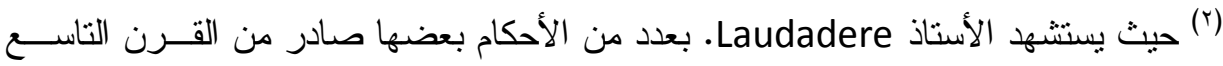

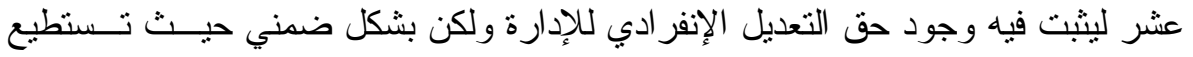

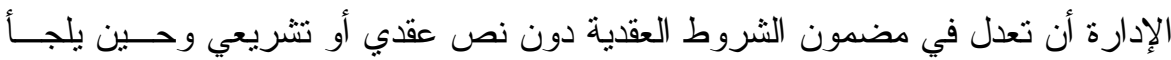

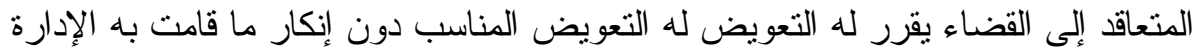

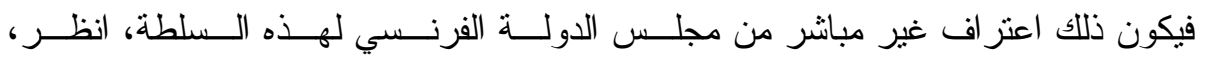
Laubadére, A. Delvoleve .P. et modern. F. traite des contrats Administratifs, L.G.D.J. Paris, TE. 1983, P. 834.

$$
\text { الإيجاب و القبول، المرجع السابق، صــ 0، وما بعده. }
$$


ثانباً: برى كل من الأستاذ Laubadére و الدكتور ثروت بدوي بأن الأستاذ

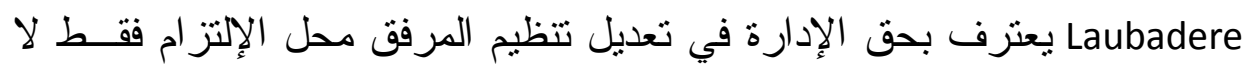

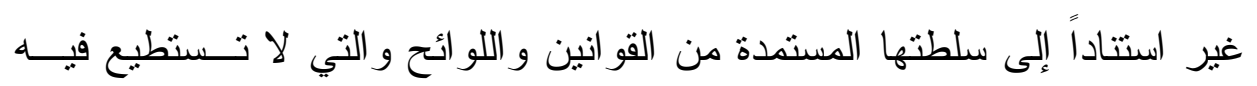
شروط العقد أن تقف أو تمنع من ممارستها وأن الإدارة في هذه الحالـــة تكــــن

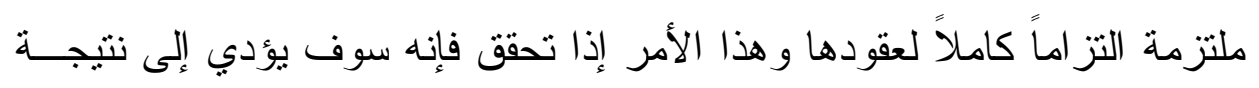

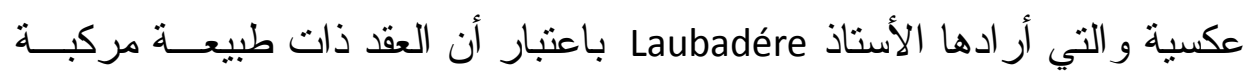

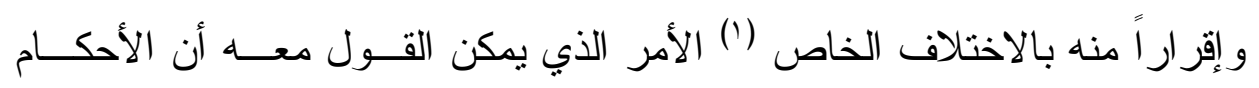
السابقة و التي ساقها الأستاذ Laubadere التأكيد لأنه لا تتفي بوجود سلطة الإدارة في تعديل العقد الإداري بإر ادتها المنفردة.

ويثير الأستاذ Laubadére هنا تساؤلاً مهماً مفاده مـــا إذا كانــت الإدارة تملك هذه السلطة في مو اجهة المتعاقد في أغلب الأحيان وفي معظم العقود فهـلـ

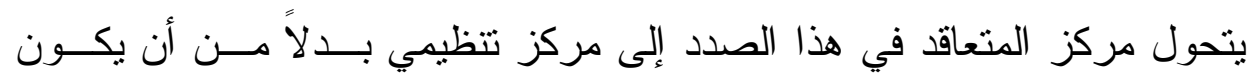

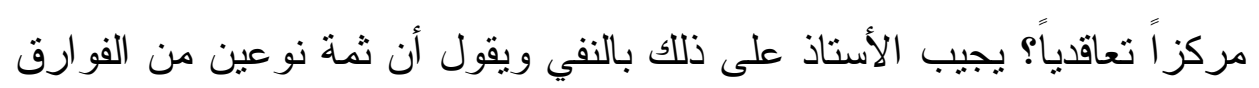
بين المر اكز التعاقدية و المر اكز التتظيمية في القـانون العـام هـــا: الأول: أن المركز التنظيمي يمكن أن يعدل في أية لحظة وليس كما هو في العقود الإدارية (1) انظر د. ثروت بدوي، سلطة الإدارة في تعديل عقودها الإداريــة، بآ9 ا، دار النهـضـة

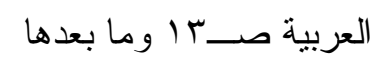

مجلتَ البحوث القانونيت والإقتصاديت 99 ب 
الثاني: أن تعديل المر اكز التتظيمية لا يترتب عليه تعويض صاحب ذلك المركز

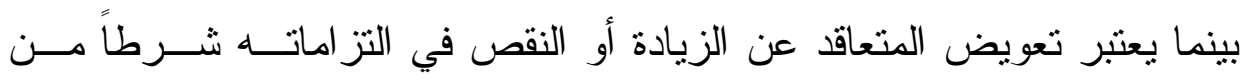
شروط استعمال سلطة التعديل. ومن جهة أخرى فأن تعديل المر اكز التتظيميــة يحتاج إلى صدور قو انين ولو ائح جديدة تنولى تعديل تللك المر اكز ، أما المركـز التعاقدي المتمثل في التزامات المتعاقد فيتم تعديله بقــرار إداري مــن الــسلطة المتعاقدة، و الثرط الوحيد الذي يمكن أن نلاحظه هنا هو ألا يؤدي التعديل بوجه عام إلى المساس بالمصالح المالية للتعاقد.

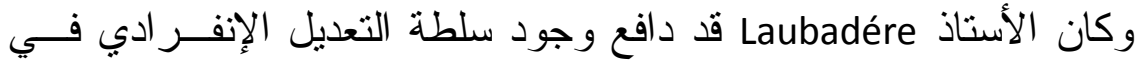
العقود الإدارية منذ سنة ؛و190 في مقال شهير له و الذي رد فيه علــى الأســناذ مستتداً على أن ما قرره مجلس الدولة الفرنسي في حكم الثر اكة العام للترام لا يستتد على سلطة في تعديل الثروط اللائحية للمرفق محـل الالتــز ام و إنما يستتد على سلطة دقيقة ممنوحة للإدارة في تعديل شروط العقد، وأن سلطة

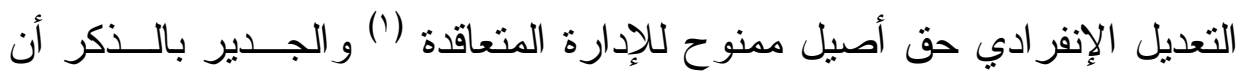

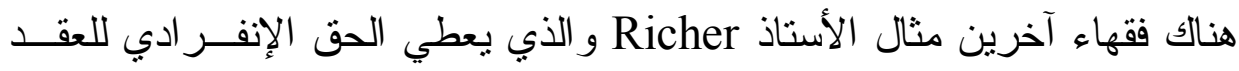
الإداري من جانب الإدارة وذلك وفقاً لمصلحة المرفق العام، وكذلك أيد الأســتاذ Burere بحق التعديل الإنفر ادي للسلطة الإدارية وفقاً لمبدأ المـصلحة العامــة 
للبدء وأيضا من ذهب (') إلبه الأستاذ Guibal بأن للسلطة الإدارية حق التعديل بإر ادتهم المشتركة وهو حق معترف لقوة القانون وذلك في نطاق العقود الإدارية

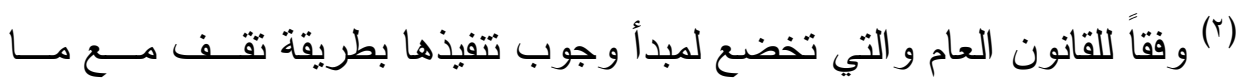
يوجبه حسن النية ووفقاً لذاتية الإيجاب و القبول في العقد الإداري. وقد قسم مجلس الدولة الفرنسي هذا الجدال نهائياً في حكمه الصادر فـي

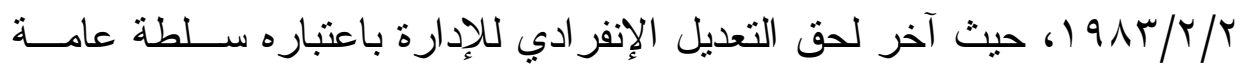

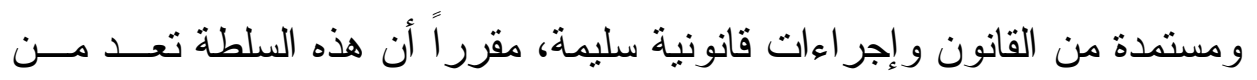

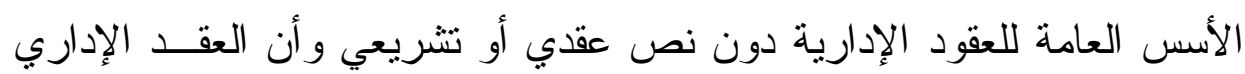

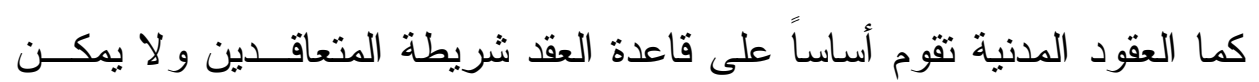

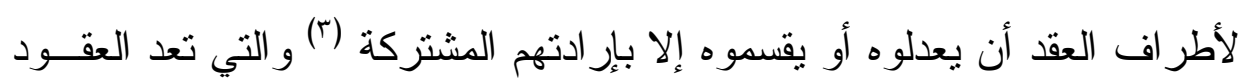

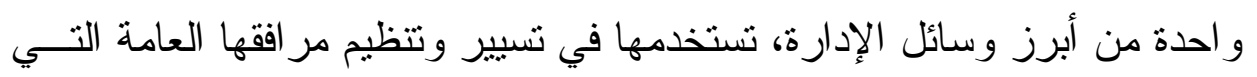
تلجأ فيه الإدارة في سبيل القبام بوظائفها وتقديم الخدمات العامة إلى إيرام العقود

Bruere. J.ch. le consensualisme et, contrats Administratifs. R. ، انظــ (') D.P. 1996, P. 1715.

Guibal. M, memento des marches publics, moniteur, paris, انظـر (r) 1998, 203.

C.T. 20-21983. Union de tramsports publics urbain, et regionaux. ، انظر

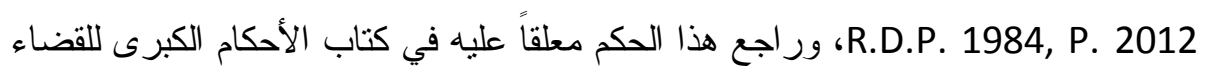

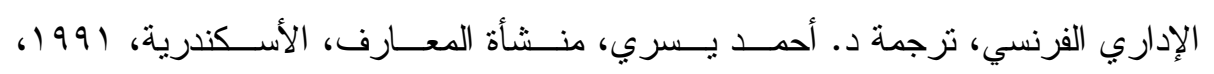

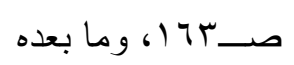

مجلتً البحوث القانونيتوالإقتصاديت ـ؛ 
و التي تتمتل بمجموعة من المبادئ التي يترنب عند الأخذ بها مصلحة الإدارة من جهة، ومصلحة المنعاقد معها من جهة أخرى.

أما موقف الفقه المصري من سلطة الإدارة في تعديل العقد الإداري: مهما

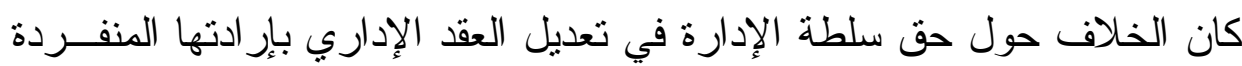
في فرنسا، إلا أن هذا الدق فوق كل شكك عند الفقه المصري، فهناك نـــوع مـنـ

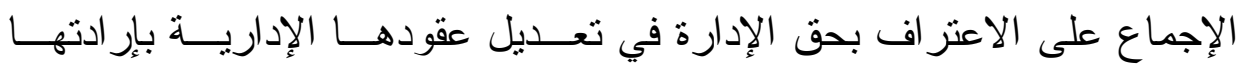
المنفردة حتى لو لم ينص عليه في العقد وفي دفاتر شروط المناقصة كثرط من

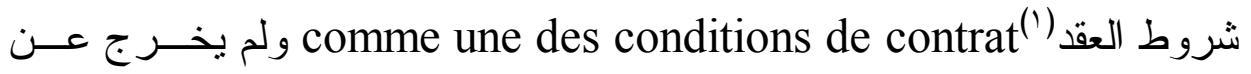
هذا الإجماع إلا أحد الفقهاء وهو الدكتور / مصطفى وصفي، و الذي ذهــب إلـى

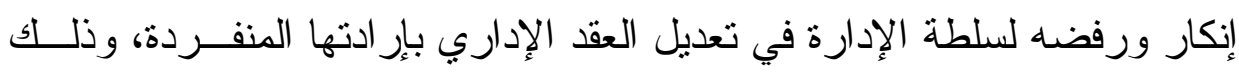

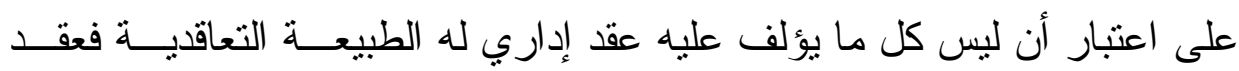
الالتز ام و عقد الأشغال العامة ليست لهما هذه الطبيعة العقدية و إنما هي من سبيل

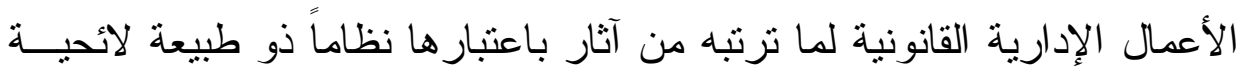

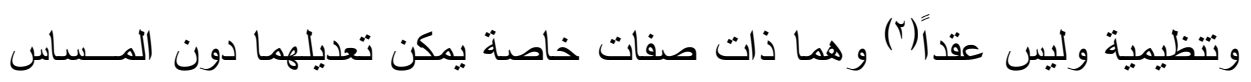

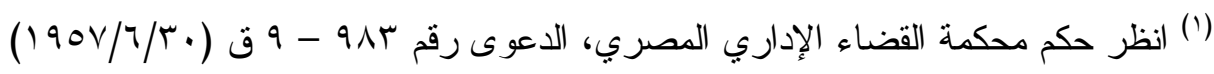

$$
\begin{aligned}
& \text {. } 7 \text {. N/TrV/ } 11
\end{aligned}
$$

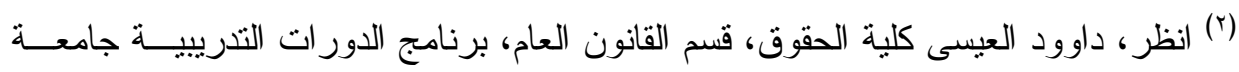

$$
\begin{aligned}
& \text { الكويت، صــا ( وما بعده. }
\end{aligned}
$$

مجلتً البحوث القانونيت والإقتصاديت ب . 
بالجوانب المالية و الفنية أما عن عقود التوريد فذهب الدكتور مـصطفى كمــال وصفي باعتبار ها من الأعمال الذاتية أو ذات طبيعة ومو اصفات خاصة يتطلبهـــا الجهة الإدارية الحكومية المتعاقدة ولذا لا يجــوز لـالإدارة تعـديلها بـسلطنها وبإر ادتها المنفردة (')، أما بقية الفقهاء المصريين اتفقو البالإجمــاع عـن أحقبـــة السلطة الإدارية بتعديل العقد الإداري بإر ادتها المنفردة دون وجود أي نص مـــاهـ يمنع ذلك منهم الدكتور سليمان الطماوي حيث برى فيه بأن سلطة التعديل إنـــا

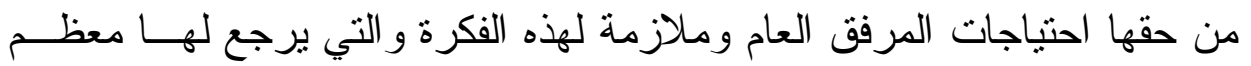

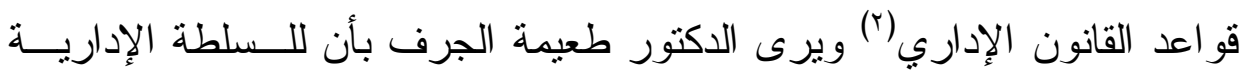
صاحبة النعاقد الحق في تعديل عقودها الإدارية أساسه هو فكرة العرفـق العسام

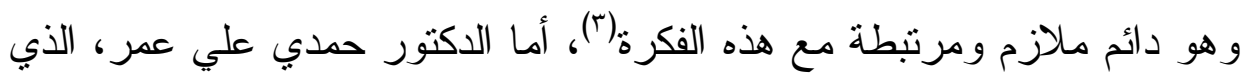

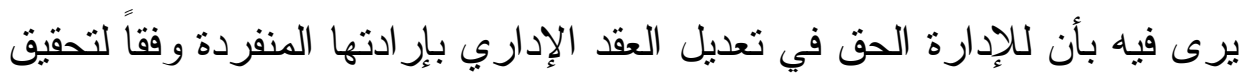

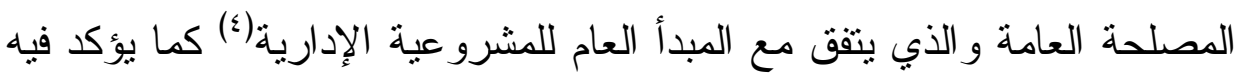

(1) أنظر ، مصطفى كمال وصفي، حول سلطة الإدارة في تعديل شروط العقد الإداري، مقــال

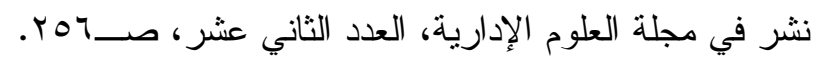

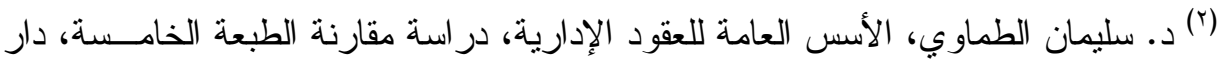

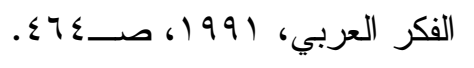

(") د. طعيمة الجرف، القانون الإداري، دراسة مقارنة في تنظيم ونثاط الإدارة العامـة، دار

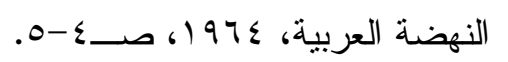

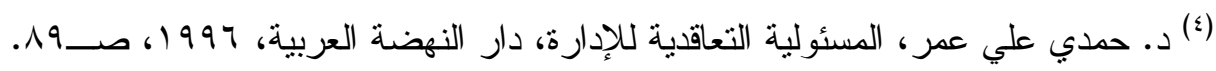

مجلت البحوث القانونيتوالإقتصاديت ب. ؛ 


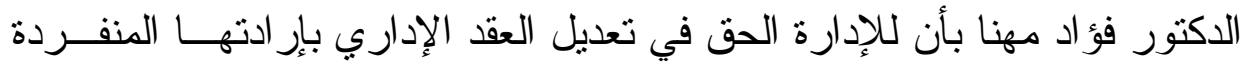
و الذي هو مسلم به بصفة عامة سو اءً من جانب الفقه و القضاء حتى ولم لم ينص عليه في العقد(')، ويؤيد الدكتور محمود حلمي. حق الإدارة في التعديل لأن ذلك

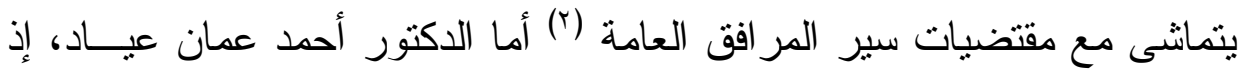

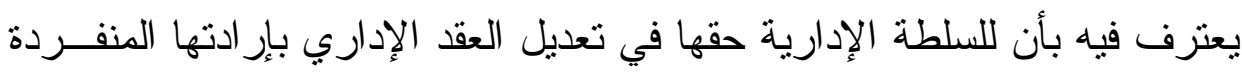

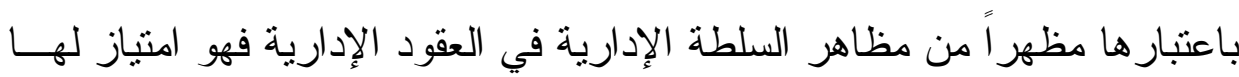

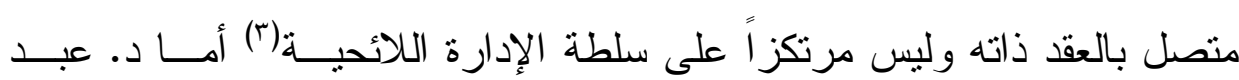

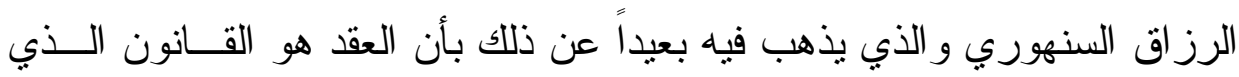

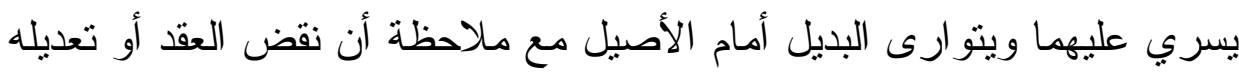
لا يجوز للقاضي أو الدتعاقدين القيام به حتى لو اعتمدنا على مقتضيات العدالـــة

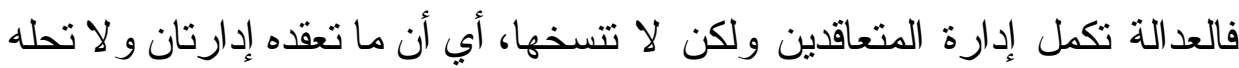

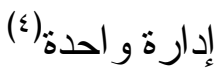

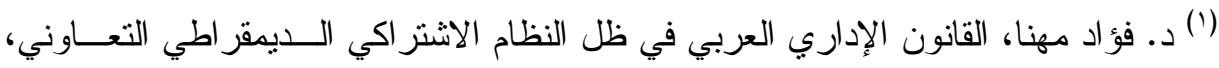

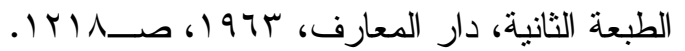

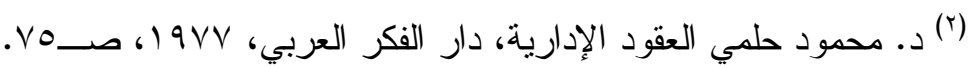

(r) انظر د. أحمد عتمان عباد "مظاهر السلطة العامة للعقود الإدارية" دار النهضة العادية العربية.

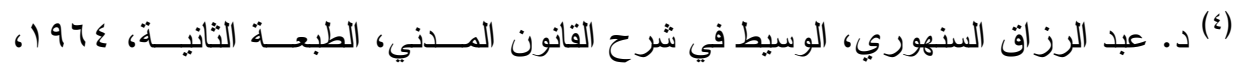

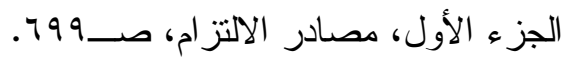

مجلت البحوث القانونيت والإقتصاديت ؛ 


\section{المبحث الثاني \\ نطاق سلطة الإدارة صاحبة المناقصة في تعديل شروط العقد الإداري بإرادتها المنفردة}

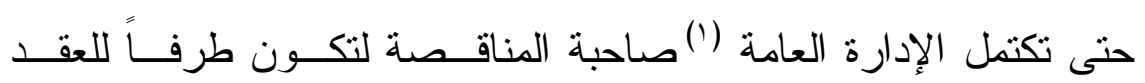
بشروط عقد المناقصة بالصفة الإدارية وفقاً للقــانون الإداري يجــب أن يتعلــق

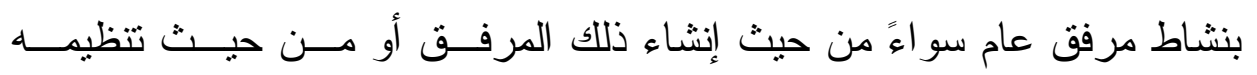

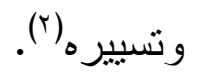

فمن المبادئ المعروفة و المسلم بها أن العقد الذي يبــرم بـين شخــصين من أثنخاص القانون الخاص يعتبر من قبيل العقود المدنية وهذا ما هو متعــارف

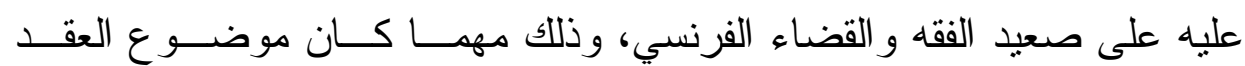
M. waline, précis de droit Administratif. 1969, Paris, 1969, P. انظــــ (') .392.

(r) لفظ الإدارة بشمل جميع الأقسام و الوحدات الإدارية في الدولة و التــي تتمتــع بالثخـصـية

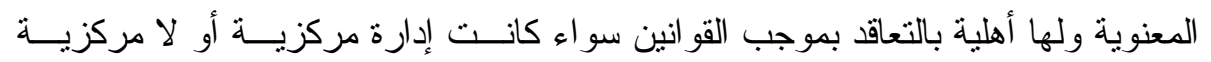

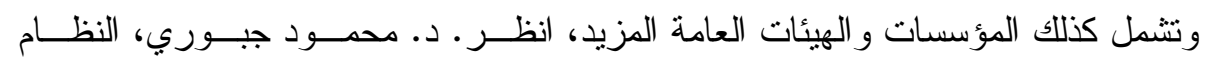

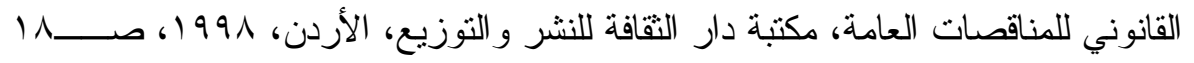
وما بعده.

مجلت البحوث القانونيت والإقتصاديت ــ 
للمناقصة أي حتى تصل بنشاط أو مرفق عــام (') علــى الــر غم أنهــا عقــود إدارية بحسب الأصل، ما لم يكون موضوع العقد يتعلق أساساً برو ابط القـانون

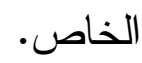

كما يعرف بموجب القانون العام بأن إذا كانت الإدارة صاحبة المناقـــة

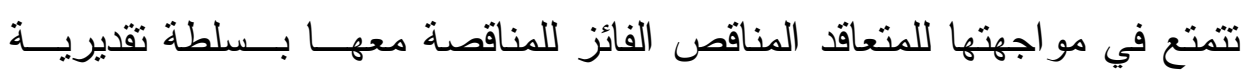

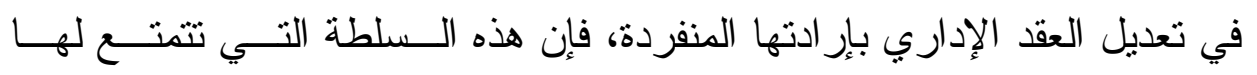

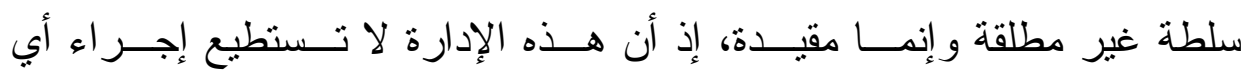

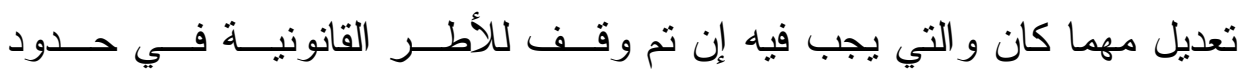
الاتفاقية أو القضائية و التي سوف هنا أن نبنيه في المطلب الأول و الثــاني فــي بحثنا هذا.

Peiser: Droit (') من الفقه الفرنسي الحديث في هذا الموضوع انظر على سـبيل المثــال Administ ratif, Dalloz. 1979. P. 47 ets. Georges Dopuis et Marie - Jose Guedom, institutions diministratives, Droit Administrat, 2 edition. .1988 P. 34. 


\section{المطلب الأول}

\section{القيود الاتفاقية لسلطة الإدارة في تعديل شروط عقد المناقصة}

و الجدير بالذكر هنا حيث من المعروف بديهياً وذلك وفقاً للقانون الإداري

بأن سائر شروط العقود الإدارية مع المناقص الفائز بالمناقصة (') تخضع وفقـاً

لأحكام قانونية باعتبار أن الإدارة صـاحبة المناقصة و المشرف عليهــا بموجــبـ

قو انين صـادرة من مجلس الوز ارء و الذي فيه يتم تخويلها للإثشر اف علــى تلــلك

المناقصات بموجب شروط وقيود خاصة و التي فيه تقوم تقوم بحقها فـي إبــر ام

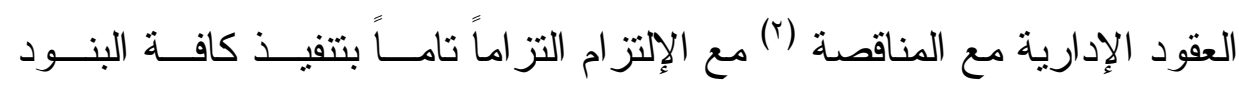

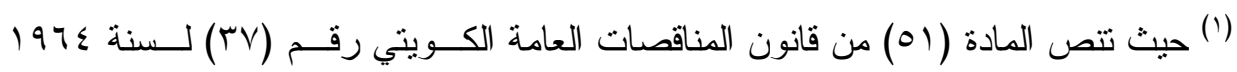

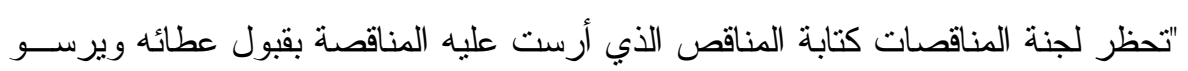

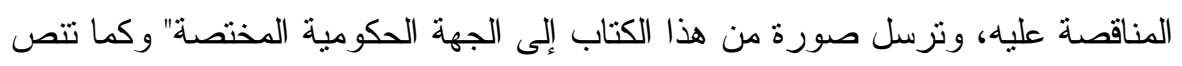
المادة (ro) من نفس القانون "تطلب الجهة الحكومية صاحبة المشروع من المناقص الفائز

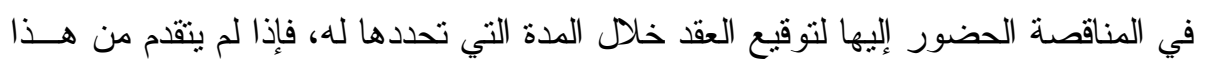
المعياد لتوقيع العقد اعتبر منسحبا.

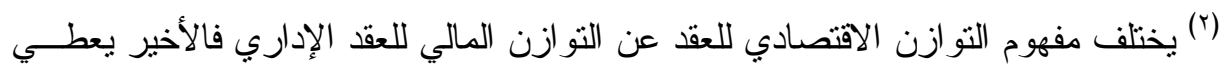

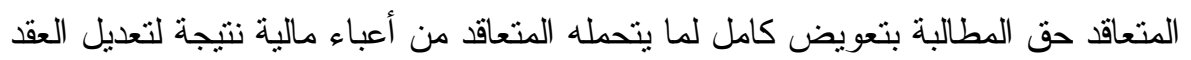

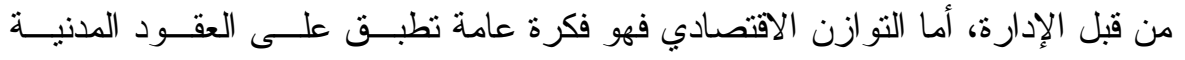

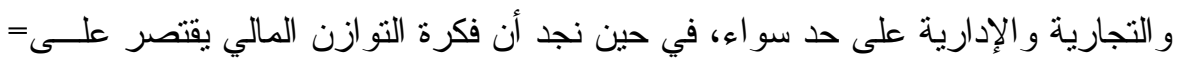


و الثروط المدونة في العقد مع تلالك الإدارة ودون الإضر ار بأي بنـــــ أو شــرط المتفق عليه في العقد الإداري على الرغم بأن ليس من الواجب أن تكون التــزام الإدارة تجاه المناقص المتعاقد الآخر معها أكثر احتر اماً من جانبها، خاصة بـــأن المتعاقد قد قبل برضاه في إير ام العقد الإداري بموجب مبدأ القبول و الإيجاب بين

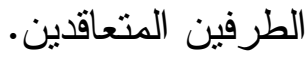

ولكن السؤال الذي يطر ح نفسه من ضوء شرحنا للقيود الاتفاقية لسلطة التعديل وهو هل تسنطيع الإدارة صاحبة المناقصة أو الإثراف عليها أن نتنازل في سلطتها فى تعديل عقد المناقصة وذللك لوجود نص و اضح ينص على ذلك؟.

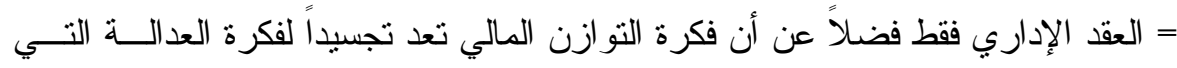

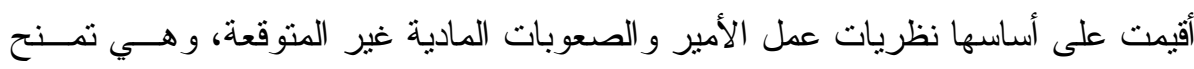

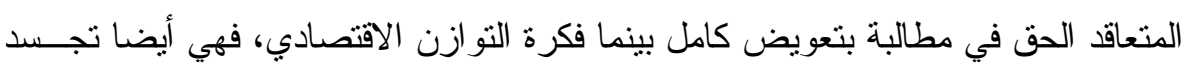

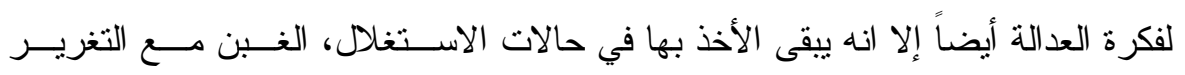

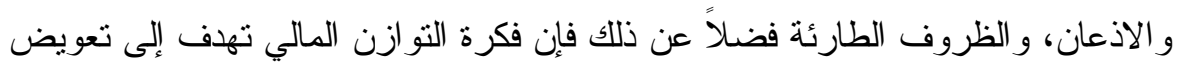

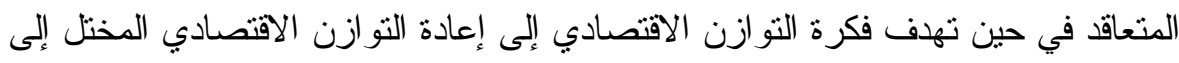

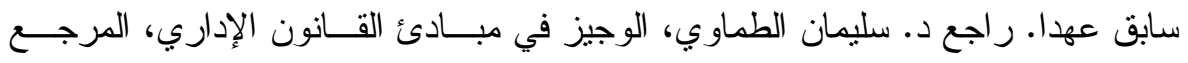

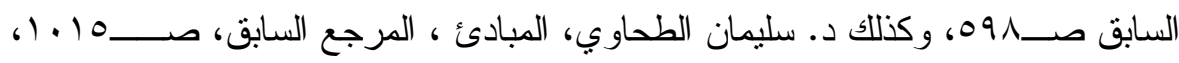

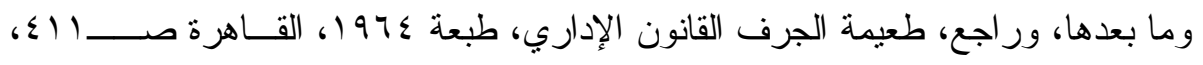

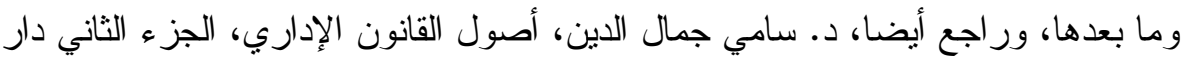

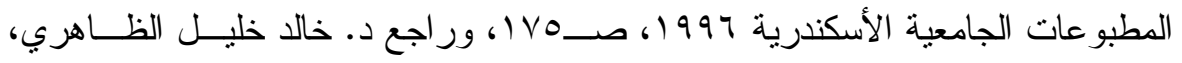

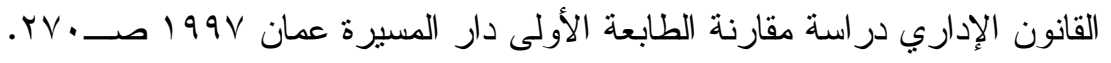


الإجابة على ذللك السؤ ال في تطابق القانون الخاص فالإجابــة بالإيجــاب

وذللك بسبب الأحكام و القو اعد التي تخضع لها العقود الإدارية تختلـــ اختلافــاً و اضحاً وخاصةً فيما يتعلق بامتياز ات بتكوين العقد و آثاره (') أما في مجــال أو ولو تطابق القانون العام فإن الإجابة تكون بطبيعة الحال بالنفي وذلك لأن فقه القانون الإداري وذلك باعتبار أن حق الإدارة صاحبة المناقصة في تعديل العقد الإداري لثروط المناقصة لا يعتمد من الحقوق الثخصية التي يتصرف بهـا صـاحبها حسب ما يرى ولكنه امتناز معترف به لها باعتباره أحد عناصر سـلطتها فـي

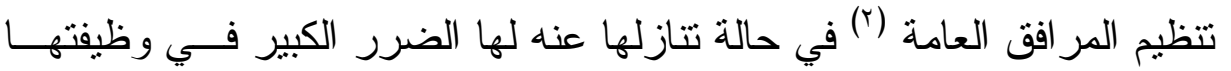
و اختصاصها الأساس كلها، وذللك استثناءً إلى الاختصاص المنوط بهــا متعلـقق بالنظام العام أي مقرر لمصلحة عامة وليس مـصـلحته الخاصــة لجهــة الإدارة صاحبة المناقصة، ولذا فهي لا تسنطيع التصرف به بالتتازل علــى اعتبــار أن

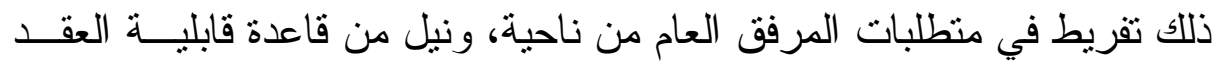

Franchis - Paul Bénoit. Le Droit Administratif, Franceais, Dalloz, راجع (1) .1968 P 597.

(r) المرفق العام: هو إثباع حاجات الناس الأساسية، وعلاقة الانتفاع من المر افق الاقتـــادية

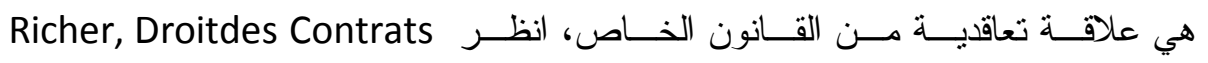
Administatifs Dalloz, Paris, 1991, P. 13 
للتغيير ولذلك فهو غير مشروع، و إذا كانت العقود أيا كان نوعها تتفق جوهرهــــ

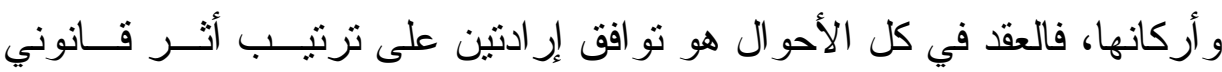

اركان هي السبب و المحل و الرضا (').

وقد أكدت المحكمة الإدارية العليا في مصر "أن العقد الإداري شأنه شــأن

العقد المدني من حيث العناصر الأساسية لتكوينه، لا يعـدو أن يكــون توافـق إر ادتين بإيجاب وقبول لإنثاء التز امات تعاقدية تقوم على التز اضي بين طــــين

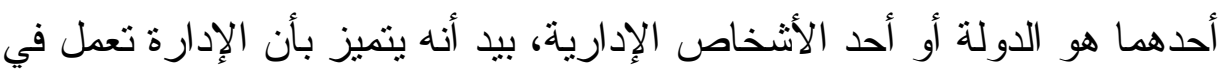
إبر امها له بوصفها سلطة عامة تتمتع بحقوق و امتياز ات لا يتمتع بمثلها المتعاقــــ معها (r) و إذا كان هذا هو رأي غالبية الفقه، فإن البعض الآخر له ر أي آخر هـــ أنه إذا كان حق الإدارة في تعديل العقد بإر ادتها المنفردة غير قابل للتصرف فيه تحقيقاً للهدف من تقريره، فإنه يجب أن يكون عاما بالنسبة لعقود القانون العسام

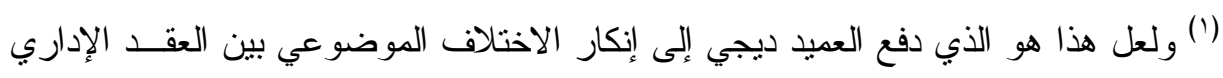

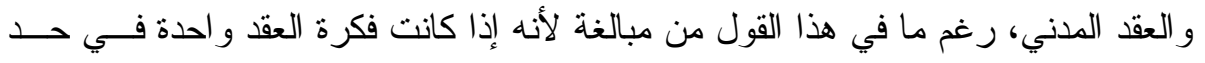

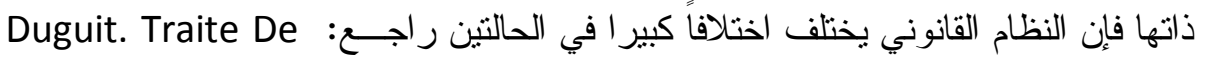
Jeze. وراجع فـي عكس هـــا الاتجــاه Droit Constitutionnel. T. 11 P. 44. Principles Generaux Du Droit Administratif. T. iH, P. 299

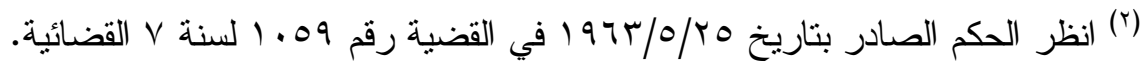


وعقود القانون الخاص التي تكون الإدارة طرفا فيها، وذلك لأن الإدارة تـسمى إلى تحقيق المصلحة العامة في الحالثين، و أن تخليها عن ذلك فــي إحــداها دون الثانية تقريط منها بو اجب أساسي من واجباتها هذا من ناحية، ومن ناحية أخرى، يقول المعارضون، فإن القضاء لم يؤكد منل هذا النظر، ولذلك فإن القائلين به لم يستندو ا إلى حكم لتناييد ما يدعون فحسب، بل ان هنالك من الأحكام مـــا ينفيـه، ويسوقون للتنليل علـى رأيهــم مجلـس الدولــة الفرنسـسي الــصادر بتــاريخ $.19 \times 1 / Y / r$.

وموضوع الحكم المذكور أن الإدارة اتخذت ضد المتعاقــــ معهــا عـــة جز اءات لتأخره في إنجاز العمل المطلوب في موعده، ولكي يتخلص منها ادعى أن سبب التأخير ناتج عن أقدام الإدارة زيادة كمية العمل المطلوب القيام به، فما كان من مجلس الدولة إلا أن قرر أن الإدارة لا تستطيع زيـــادة كميــة العـــل المطلوب إنجازه على خلاف ما هو وارد في العقد (')

(') انظر، د. داوود العيسى، سلطة الإدارة في تعديل العقد الإداري، و الــضمانات المتــوفرة

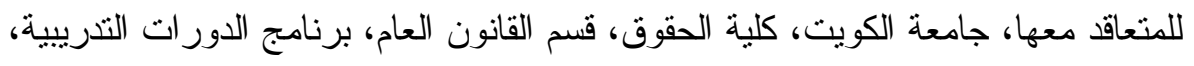
بدون تاريخ، صـا9 19 و وا بعدها، وكذلك راجع حكم مجلس الدولة الفرنسي الصادر بتاريخ

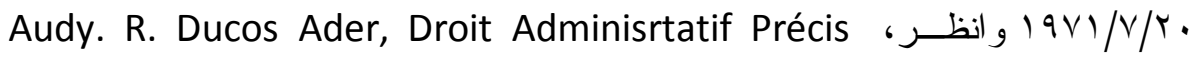

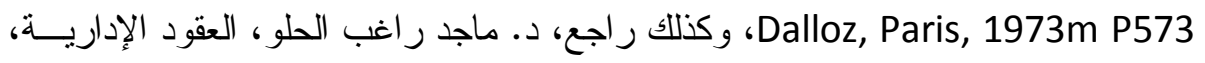

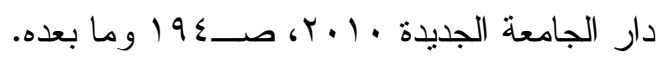

مجلت البحوث القانونيت والإقتصاديت 1 
ومن ضوء النص لنص الحكم هذا يرى وجوبا هنا أن تـستخلص بعـض الملاحظات استتادا إلى الحكم وهي:

() جو از تتازل الإدارة الحكومية عن حقها في سلطة التعديل للعقد.

r) اعنز (ف مجلس الدولة تضمن بأن العقد له نصوص و اضحة على حرمسـان الإدارة من إجر اء التعديلات على العقد.

r) احتر ام القضاء لإر ادة الدولة المنفردة بالتتازل الجزئي عن حقها في تعسديل العقد.

ع) على عدم اعتر اف القضاء بحق التتازل كليا للطرف الثاني وهو الدنــاقص وذللك بسبب عدم قبوله بالثرط الذي يحرم بموجبه أحد طرفي العقد وهــو الجهة الإدارية عن استعمال حقه.

0) عدم حرمان المتعاقد مع الإدارة (المناقص أو الدقاول) من حقه التعـويض مقابل حق الإدارة صاحبة التعاقد في تعديل العقد.

T) موقف القضاء لا يتغير حتى في مو اجهته بوجــود نــص صــريح علـى التتازل كلياً عن حقه في التعديل باعتباره يرفض مبدأ التتازل كلياً للطــرف كرف

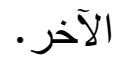

مجلت البحوث القانونيت والإقتصاديت r اء 
ع على الرغم من مشروعية الثروط المنصوص عليه في العقد ضمن نطــاق

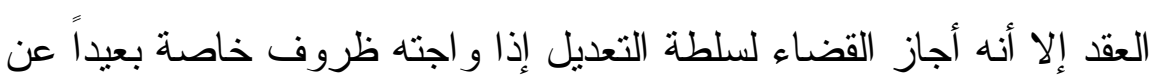
شروط عقد الإذعان ('). ^) تحقيق مبدأ حسن النية و العدالة المشتركة بين المتعاقدين وليس على حساب

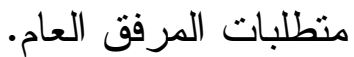
9) تحقيق المصلحة العليا للبدء على المصالح الخاصة سواءً وفقاً للقانون العسام أو الخاص وذلك بموجب حق الانتفاع بخدمات المرفق العام(؟).

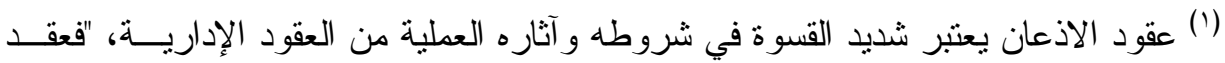

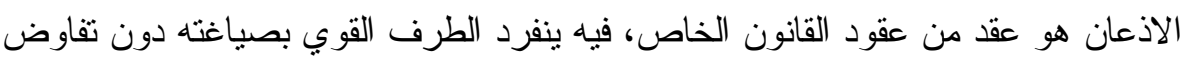

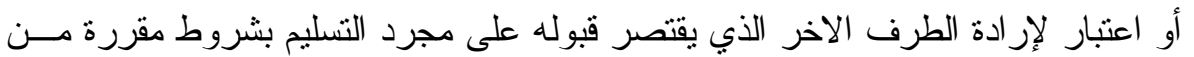

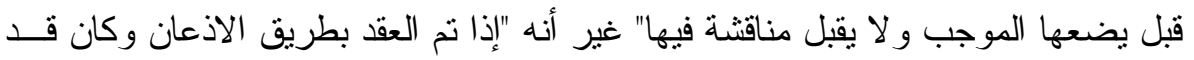

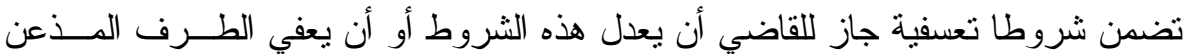

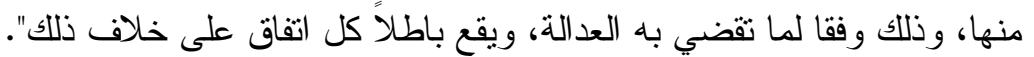

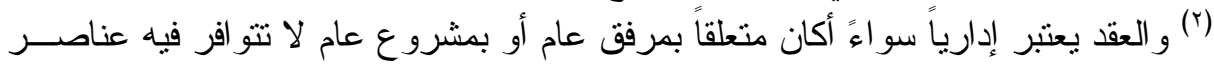

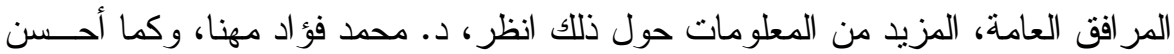

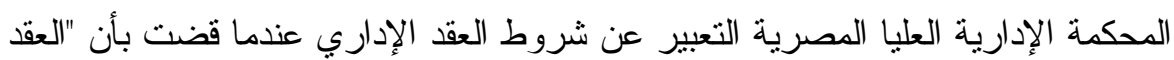

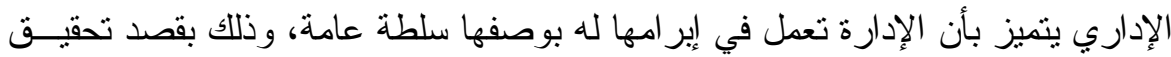

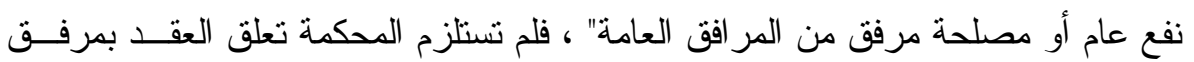

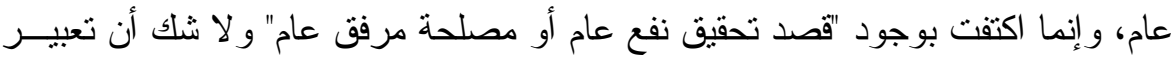

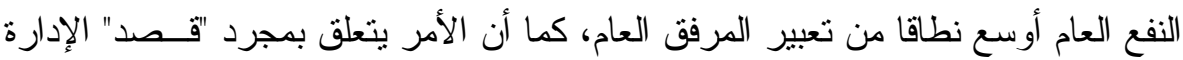

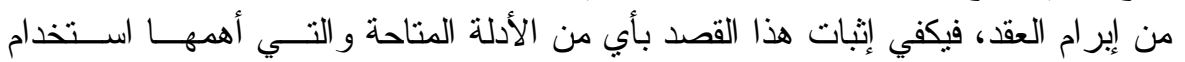

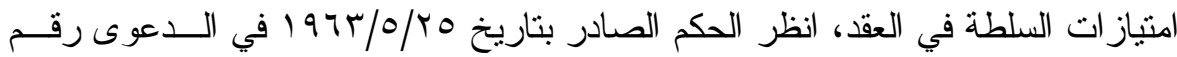




\section{الاطباب الثاني}

\section{القيود القضائية للساطة الإدارية في تعديل العقد للمناقصة}

قبل مناقثة هذا المطلب لا بد أن نطرح سؤ ال وهو، هل عدم وجــود أي

قيد أو شروط للعقد هو اعطاء السلطة الإدارية صاحبة التعاقد للمناقصة الحريــة

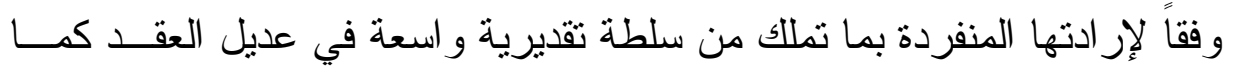
تشاء؟

تمارس السلطة الإدارية اختصاصها وحقهـــا فــي ظــل قيـــود محــددة

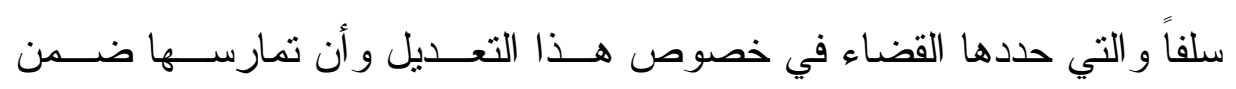
هذا النطاق و لا تخرج عن نطاقـــ؟ وهـلـ تمــارس ســلطة الإدارة صــاحبة المناقصة ضمن نطاق العقد الأصلي دون أب إضافة بشأنها وذلك بعد تحييــدها بالقيود المحددة من قبل القضاء وذللك بعدم المو افقة على إقر اره لبعض التعديلات

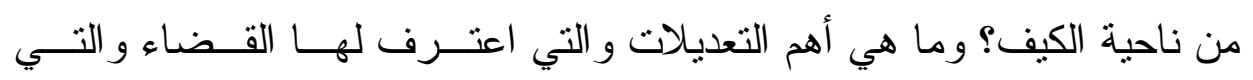
تم حصر ها ضمن نطاق محدد من ناحية الكم ليقوم به الإدارة ضمن اختصاصها

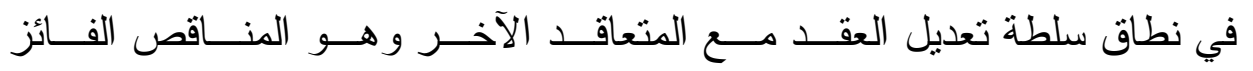
بالمناقصة؟ و الإجابة على جميع هذه التساؤلات وجوباً علينا أن نميز بين نوعين من القيود القضائية لسلطة التعديل و التي يجب فيه الإدارة صاحبة المناةـصة أن

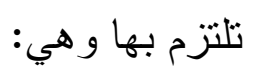

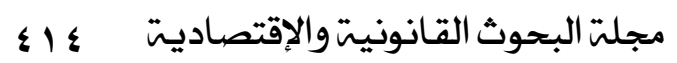




\section{النوع الأول: القيود النوعية على سلطة الإدارة}

إذا كانت سلطات و امتياز ات الإدارة صـاحبة المناقصة و المــشرف عليهــا في مجال العقود الإدارية المتعاقد مع المناقص الفائز أب الطرف الثاني من العقد و اسعة النطاق فإن قيوداً معينة تقابلها في بعض الأحيان مما لا نظيــر لــهـ فـي العلاقات التي تقوم بين أطر اف عقود القانون الخاص و علــى الأخــص نحــن بصدده من هذه السلطات و الامتياز ات ونعني به ما تتمتع به الإدارة من تعـديل

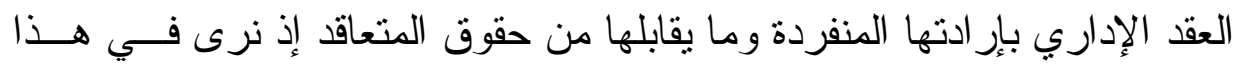
الصدد بأن هنالك قيود نو عية على سلطات الإدارة الحكومية المتعاقدة بحيث تحد من إر ادتها وتعديل العقود كما تشاء وأن أحكام القضاء هو الوحيــد إقــــراره أو رفضده لمنتل هذه التعديلات وليـست جهـــة الإدارة الحكوميــة وفقــاً لــسلطاتها و امتياز اتها بحيث تكون مشرو عيتها القانونية محددة جدا مــع اعطــاء حقـوق المتعاقدين الآخرين حقوقا بالتعويض وفقاً لمبدأ التو ازن المالي للعقد، وذلك على سبيل المثال لا الحصر وهذا بنطبق على أقدام الجهة الإدارية الحكوميـــة علـى استبدال المو اد المستعملة بمو اد أخرى أو إقدامها على عملية تعديل الهيكل العـام أو عمل تصميم آخر للمشروع إنشاءه سو اءً زيادة حجمه أو تقليله، ولكن يختلف 
الأمر ، إذ أن ثبتت حق التعديل الانفر ادي بمقتضى النصوص التشريعية و أحكـام القضاء الإدارية المستقرة وتأييد غالبية الفقه المصري('). و الجدير بالذكر هنا بأن هذه النوعية من القيود على ســلطة الإدارة هـــي نادرة الحدوث وقلتها وذللك بعدم الخروج عن أحكام القضـاء الإداري فـي هـــا الخصوص باعتباره تجاوز ذلك إلى جوهر العقد الذي حدى بالتعاقدين إلى عقــد لا يمكن أن تتال شروط العقد المالية و لا موضو عه و الذي على اساسه بني هــــا

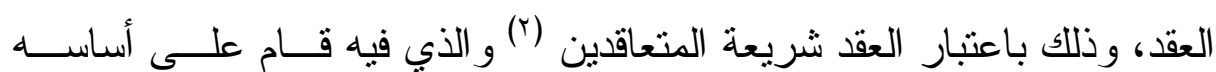
الإيجاب و القبول أي تو افق إرادتي بقصد إنشاء آثار قانونية الذي ينـشأ مباثـــرة

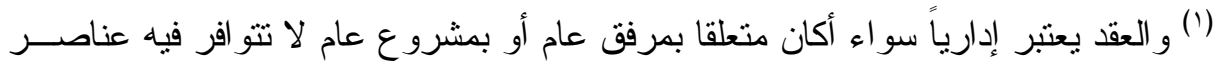

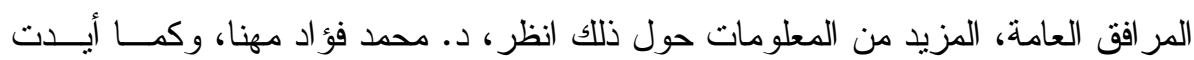

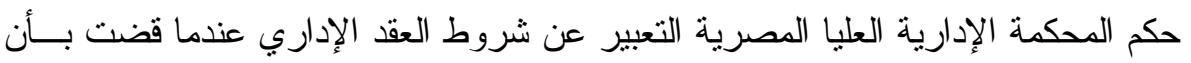

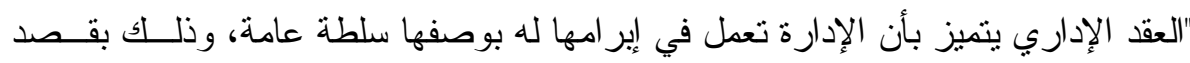

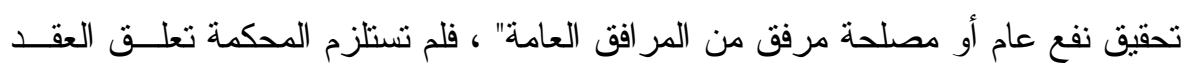

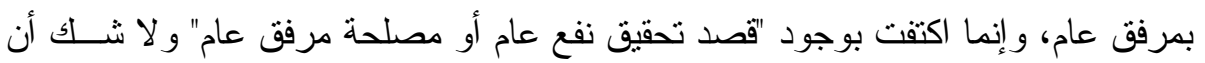

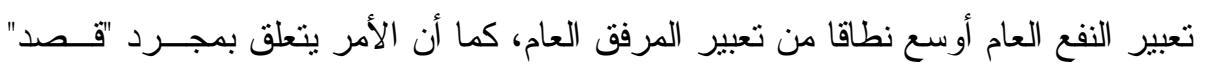

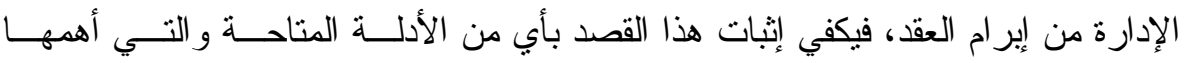

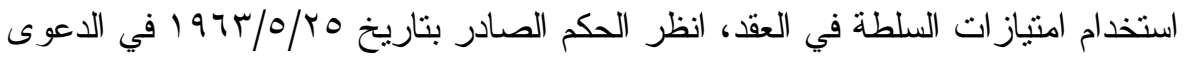

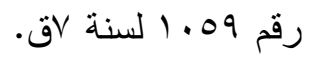

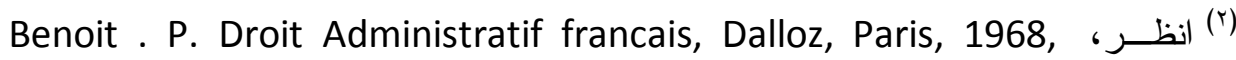
P.G16. 
من الفعالية الإدارية لأطر اف العقد (') وذلك يقود إلى نتيجة هامة جدا مقتضاها أن العقد الإداري للمناقصة يستمد قوته الملزمة من حيث الأصــل مــن الإر ادة الحرة لطرفيه، دون الحاجة إلى الاستتاد على ســلطة القــانون، فــالإر ادة هـــي

$$
\text { الأساس المباشر لهذه القوة(؟). }
$$

أما من حيث خصوص سلطة الإدر اة صاحبة المناقصة في تعديل جــوهر العقد فإن هذه الإدارة لا تستطيع أن تفرض على المتعاقد (المناقص) معها القيــام بعمل مختلف تماماً في جوهره (المضمون) ما نص عليه فــي العقــد الأصــلي بحيث يصبح المتعاقد وكأنه في مشروع جديد أي الأعمال المنصوص عليه فـي العقد الأصلي ليس له علاقة في العقد فإن تتفيذها يتطلب شروط جديدة تختلـــ تماما عن شروط العقد الأصلي وهذه الأعمال يختلــف عليــهـ مجلــس الدولـــة الفرنسي بالأعمال الغربية أو الأجنبية في العقد.

Lebreton.G. Droit Administraif general. Armand - colin paris, انظـــ (') 2000, ed2. P233. وطالما أن العقد شريعة نعاقدية الذين أنشأوه بإر ادتهم الحرة، فــلا

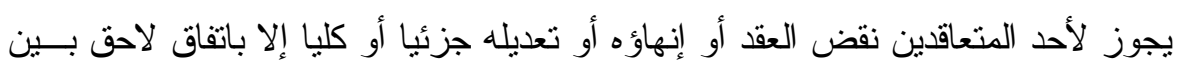

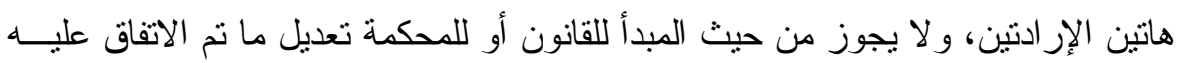

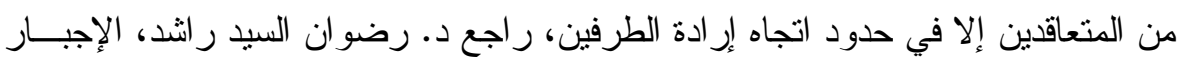

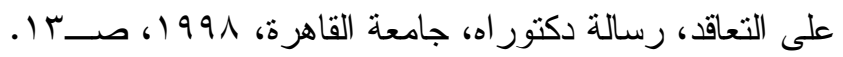

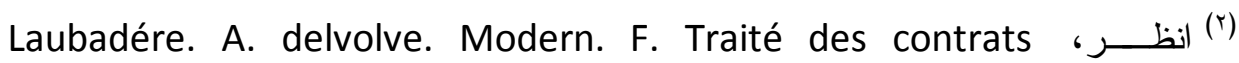
administratifs, L.J. Paris, 1981, P29 


\section{النوع الثاني: القيود الكمبة على سلطة الإدارة:}

وفقاً لأحكام القاضي الإداري هو الوحيد الذي يستطيع أن يمنــع أو علــى الأقل أن يخفف من التعديلات وفقاً للسلطة الإدارية صاحبة المناقصة التي تقــوم بإخلال هذه التعديلات على العقد المبرم مع المناقص وفقا لثروط العقد المتهـق عليه للطرف و التي قد تكون هذه التعديلات بالزيــادة علــى التز امــات كثيــرة ويصعب حصر ها مما يكلف هذه التعديلات المناقص (المقاول) التز امات ماليــة مكلفة وباهظة يستحق عليه التعويض، لذا فإن التوازن المالي للعقــــ الإداري (') ارتبط ارتباطاً وثثقاً بحق الإدارة في تعديل عقدها مع حق المتعاقــــ بــالتعويض المالي بقدر ومساوي قيمة التعديل على العقد التي أجرته هذه الإدارة وهو حــق ليس لله وجود في عقود القانون الخاص ويعنـي التــوازن العــادل للالتز امــات و الحقوق في العقد الإداري، ومع تعدد آراء الفقهاء بشأن الأساس الذي تقوم عليه

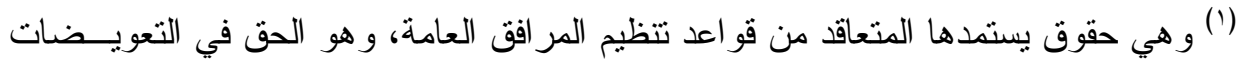

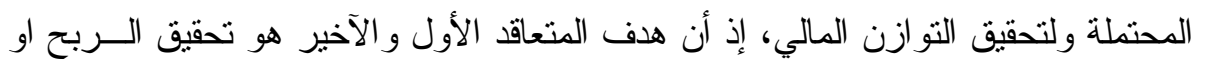

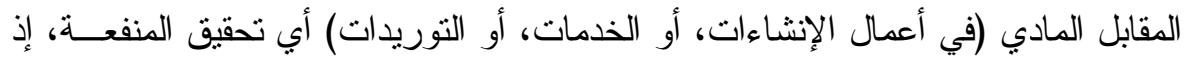

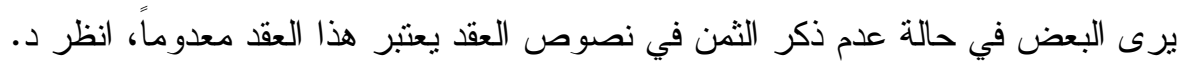

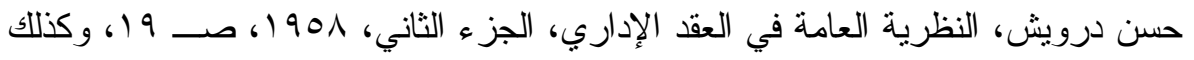

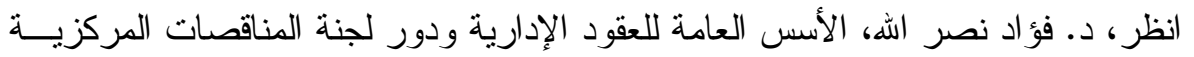

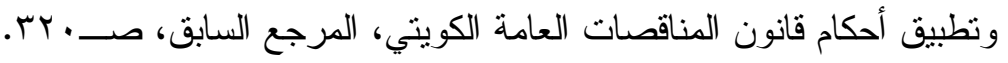


هذه النظريات، إلا أنها تتبع جميعها من مبادئ أخلاقيــهـ و عمليـــة هــــ العدالــة

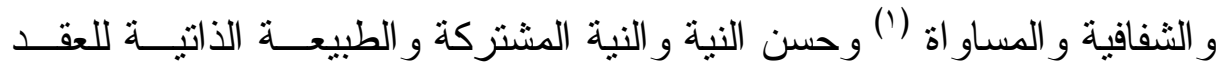
الإداري وصلته بنشاط المرفق العام وذلك كله تحقيقاً للمصلحة العامة و الجــدير بالذكر هنا بأن المحاكم الكويتية الإدارية ينظر بالمناز عات الإدارية حيث تــنص

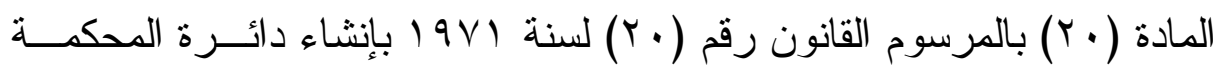
الكلية، تختص الدائرة الإدارية وحدها بنظر المناز عات التي تتشأ بـين الجهـات الإدارية والمتعاقد الآخر في عقود الالتز ام و الأشغال العامة والتوريد أو أي عقد إداري آخر وتكون لها فيها و لاية القضاء الكامل".

ومما لا شك فيه أن وضع حدود على سلطة الإدارة فــي تعــديل العقـــ الإداري بإر ادتها المنفردة منل "قلب اقتصاديات العقد" أو ما يشكل اعتداد علـىى جو هره تحتاج في حد ذاتها إلى تحديد مما يحتم ترك مـسألكة تحديــــ محتو اهـــا للتقدير المطلق للقاضي وهذا ما تعكسه بعض أحكام مجلـس الدولــة الفرنسـي

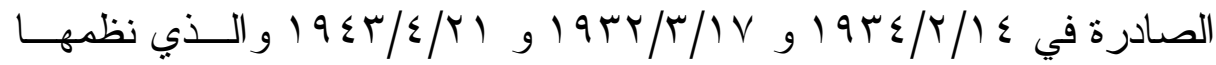

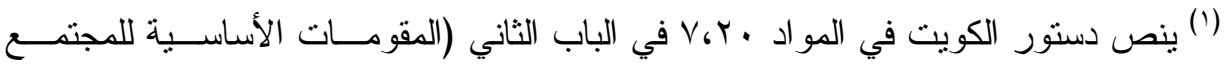

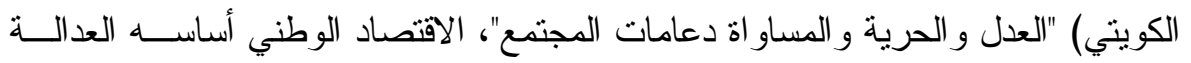
الاجتماعية وقو امه التعاون العادل بين النشاط العام و النشاط الخاص، و هدفه تحقيق التنمية

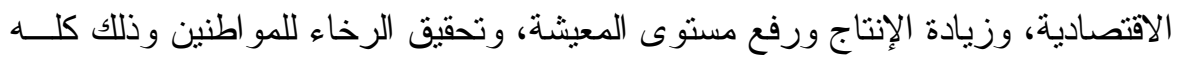
في حدود القانون". 
القضاء الإداري لمجمو عة من النتائج لهذه السلطات بوصفها سلطات عامة تمنلك حقوق و امتياز ات استثنائية في علاقتها للأفر اد (') أهمها: () إن عدم النص على أي مظهر من مظاهر هذه السلطة في العقــــ الإداري

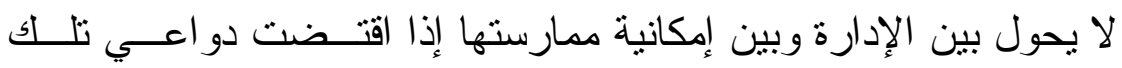

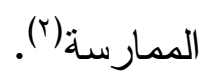

r) النص على بعض مظاهر تلاك السلطات في العقــــ الإداري دون الــبعض الآخر لا يحول ذلك بين الإدارة وبين استعمال سلطاتها جميعا.

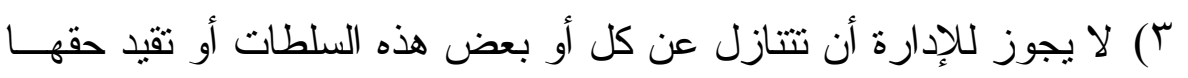
في استعمالها بقيود إلا على سبيل المثال وبما يؤدي إلى تحقيق مــصالح عامة ويعتبر باطلاً كل اتفاق يخالف هذه المبادئ.

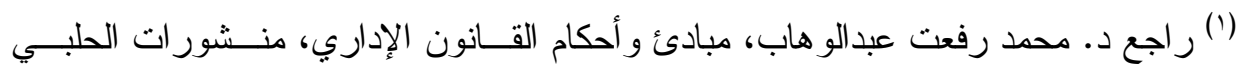

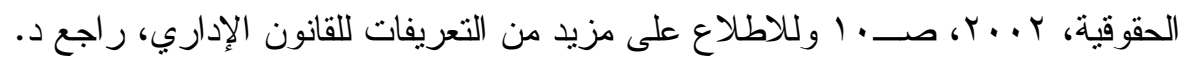

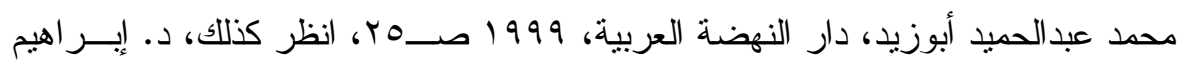

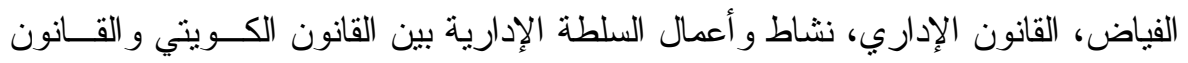

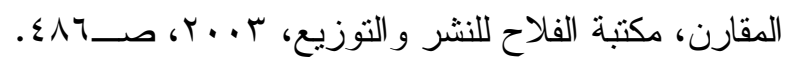

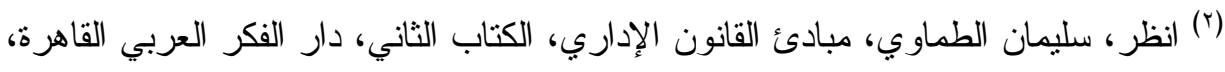
.$\leqslant \leq 7-$ ص 6 $19 \vee 9$

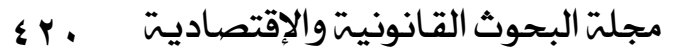


ع) إن استعمال الإدارة لسلطاتها قبل المتعاقد مر هون بتحقيق شروط معينــة تمليها طبيعة ممارسة الوظيفة الإدارية بوجه عام (').

وكل ما يمكن القول عن موقف القضـاء بعد تمحيصه في هذا الخـصوص أنه يفتقر إلى الوضوح في تأكيده لهذه السلطة بأحكام تعتبر مــن المبــادئ فــي

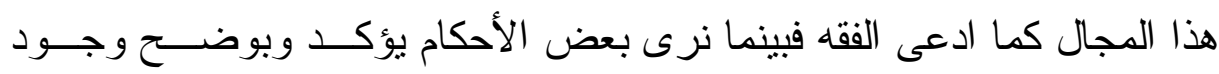

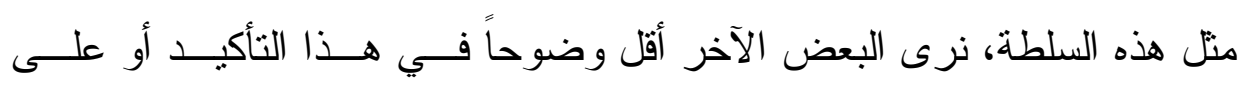

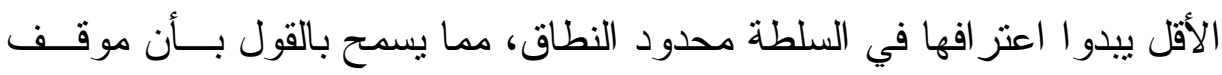
القضاء من هذه المسألة لا يمكن من الخروج بفكرة واضحة ودقيقة عـن هـــا

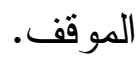

هذا وسوف نعرض موقف كل من القضاء الفرنسي و المصري و الكــويتي

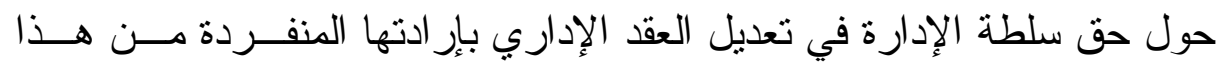
المطلب من البحث وفقاً للمحاور التالية:

J. Rive Ro, Precise de Droit Administratives, Dalloz, 10 ed. 1963, ، انظر (") .P.446.

مجلة البحوث القانونيتوالإقتصاديت ابع 
المحور الأول: موقف القضاء الفرنسي في حق السلطة بتعديل العقد الإداري

\section{يار ادتها المنفردة}

موقف القضـاء الفرنسي من سلطة الإدارة في تعــديل العقــود الإداريــة بإر ادتها المنفردة غير و اضح ولم تتضح الرؤية السليمة و القاطعة في اتخاذ حكم قاطع ونهائي و إنما تتخلب الأحكام لحين لآخر بين حق التعــديل و إنمـــا هنــالك شروط معينة تحد من اتخاذ حكم نهائي بشأنها فـي هــذه المـسائل، إذ نــر اى الاعتر اف صر احةً بوجودها ومرة أخرى يغير أحكامه بذلك مــع حـــره فــي نطاق معين عن العقود الإدارية ومرة بوسع مع نطاق تطبيقه ولكــن بأســلوب وطريقة ضمنية.

إذا كانت سلطة الإدارة في تعديل العقد الإداري وفقاً لــلإِدارة الإنفر اديـــة يستتد على فكرة التغير في ظروف المرفق العام الذي يتصل به العقــــ فإنـــهـ لا

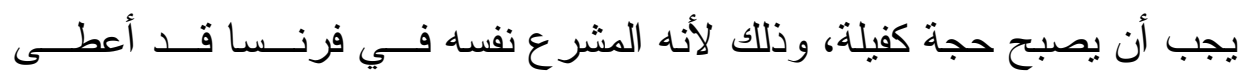

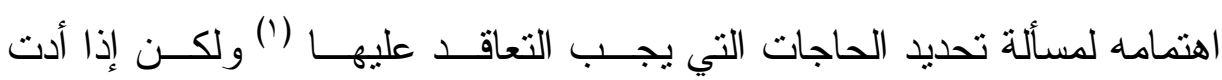
ممارسة الإدارة لسلطتها في التعديل الإنفر ادي إلى تسبب ضرر للمتعاقــد مـنـ خلال التز اماته فإن ذلك يستدعي تعويضه نتيجة تتافي أعبائه، كما هو الحال عند (') انظر د. مهند مختار نوح، الإيجاب و القبول في العقد الإداري، المرجع السابق، هبا . 
تطبيق نظرية الأمير باعتبار أن سلطة التعديل الإنفر ادي هي إحـدى تطبيقاتهــا وبذلك قضى مجلس الدولة الفرنسي (').

(Le préjudice eprouve par la ville de saint-maloa' cette decision doit, meme en l'abs cénce de toute stipulation expresed cahner de charges applicable au cas de l'espéce, étre réparé par l'etat......)

فلقد ر أينا كيف أن حكـم مجلـس الدولـــة الفرنسـسي الـــادر بتــاريخ

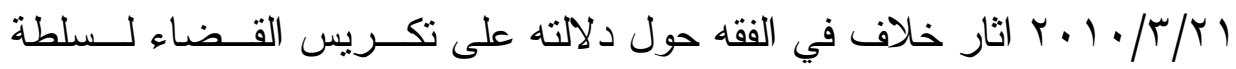
الإدارة في تعديل العقد الإداري بإر ادتها المنفردة، وكيف أن البعض قد اعتبــره حكم المبدأ في هذا المجال في حين أنكر عليه البعض الآخر متل هـــا الــدور، وكان السؤال الذي طلب من مجلس الدولة الفرنسي الإجابة عليه في هذا الحكــ هو ما إذا كان باستطاعة الإدارة أن تعدل بإر ادتها المنفردة جدول مو اعيد ســير

(') انظر د. عادل عبد الرحمن خليل، آثار العقود الإدارية ومــشكلات تتفيــذها دار الثقافــة

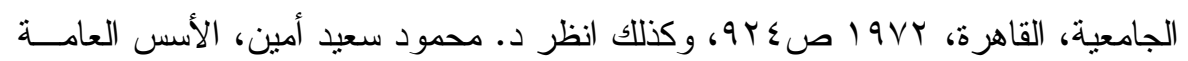

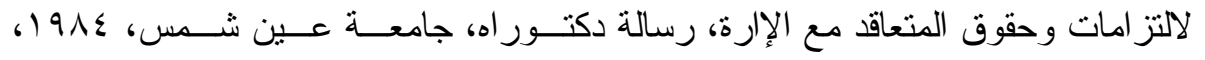

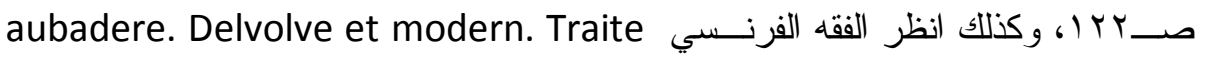
Guibal, m. memento, op cite, P. و وانظر de contrats t2. Op. cite P. 406 
القطار ات على خلاف ما وردت به في دفتر شروط الالتز ام و الذي كان جــواب المجلس المذكور عليه بالإيجاب مما أثار الخلاف بين الفقهاء حول ما رمى إليـــ

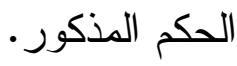

في النهاية فإن حكماً صدر في / 19 ا قد وضع حدا للخلاف حـول

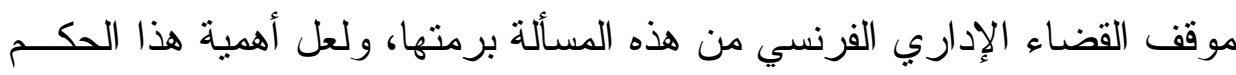
لا تأتي من اعتر اف القضاء بسلطة الإدارة في تعديل العقد بإر ادتها المنفردة فقط

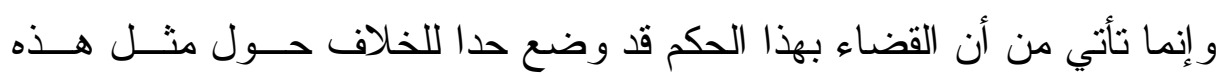
السلطة بصورة نهائية وذللك باعتباره إياها من القو اعد العامة التي تحكم العقـود الإدارية، كما أن هنالك حكم آخر في نفس المعنى صادر في $1910 / 0 / 7$. و الجدير بالذكر أن الخلاف حول آراء الفقهاء و القضاء الفرنسيين ينــصب

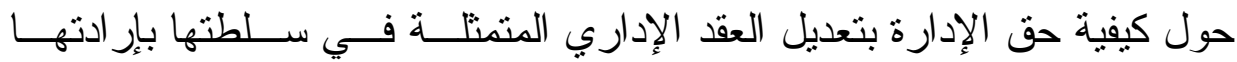
المنفردة حول المر افق الإدارية البحتة تمييز الها عن المر افـق الآخـرى، إذ أن المر افق العامة الاقتصادية منها المهنية و الصناعية و الاجتماعيــة كلهـــا مر افـق إدارية في الأصل إذ أن الإدارة هي التي تتظمها وتسـييرها (')، فقـد تحـدثت

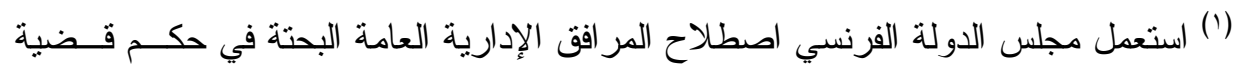

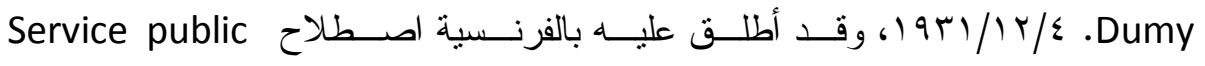
proprement dit المرفق العام بأنه محور القانون الإداري ونشاط من أنشطة الـسلطة 
الأحكام القضائية الفرنسية في الأولى و هذا الــشأن حــول المر افـق التجاريـــة و الصناعية في قضية الثركات التجارية لأفريقيا الغربية (').

المحور الثاني: موقف القضاء المصري في حق السلطة لتعديل العقد الإداري

\section{بيار ادتها المنفردة}

المطبق في القانون المصري هو اعثر افه بإقرار ســلطة الإدارة صــاحبة

المناقصة أو المشرف عليها في تعديل عقودها الإدارية بإر ادتها المنفردة، حيــث

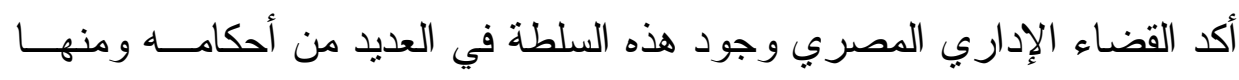
على سبيل المثال لا الحصر، حكم المحكمة الإدارية العليا عنــدما أكــدت فـي لهي

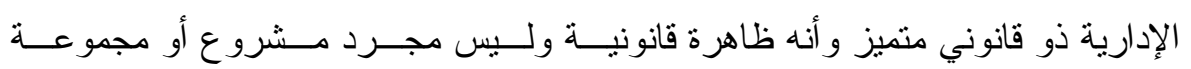

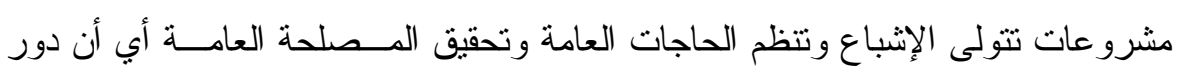

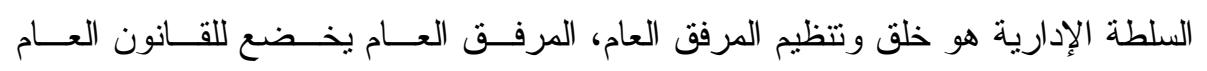
ولاختصاص القض هاء الإداري Delaubadere, A. traite theorique et pratique des contrats Admininsrtifs, paris, tom ler 2 ed L.g.d.j 1956 P864 ،T.C.22 jan 1921 Societe commericale de L'ouest africain R.91 انظـــ (1)

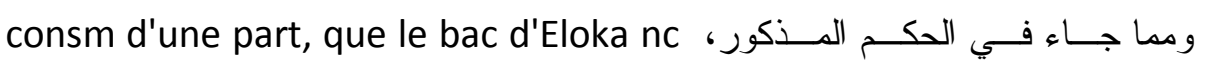
constiture pas un ourrage public, d'utre part qu'en effectuant, moyennant remancration les operations de passage des pictons $d t$ des Voitures d'une rive al'autre de la lagune, la colonie de la cote d'voire exploite un service de transport dans les memes conditions d'un industriel ordinaire.

مجلت البحوث القانونيتوالإقتصاديت هץ ع 
حكمها "بأن للإدارة دائماً حق تغيير شروط العقد و إضـافة شـروط جديــدة بمــا يتز اوى لها أنه أكثر اتفاق مع الصالح العام دون أن يتحدى الطرف.

\section{الإطباب الثاني}

\section{هوقف القضاء في هسألة سلطة الإدارة}

\section{في تعديل العقد الإداري بإرادتها المنفردة}

قد يتفق أحكام القضايا التي تصدره المحاكم وتكييفها قانونياً وفقاً لتقدير ات القضاة في إصدار أحكامهم متداخلاً فيه وفقا بطبيعة وموضوع وظروف أهميتها وضرورتها لبند القضايا الإدارية التي تعرض أمامم وما ذهب إليه رجال الفقــه سو اء الفرنسي أو المصري أو غيرهم من رجال الفقه حول كيفية إقناع وتأكيــد أداؤهم مستتداً للحجج و البر اهين و الاعتر افــات الــصريحة و الو اضـــحة و عــدم اكتنافها بالغموض سو اءً منهم المؤيدة أو المنكرة أو رفضهم لمدى حــق سـلطة الإدارة في تعديل العقد الإداري المبرم بين المتعاقدين بإر ادتها المنفردة الموجبــة لنظر المعارضين لهذه السلطة.

هنا في موضو عنا هذا حول موقف القضاء في مسألة سلطة الإدارة فـي

تعديل العقد الإداري بارر ادتها المنفردة يجب الفصل بين تلك الخلافات بين رجال الفقه ووضعها في بوتق و احد و الذي يجب فيه الفصل بين المطلوب إقامته الدليل عليه و الو اقع الذي عليه القانون الوضعي. 


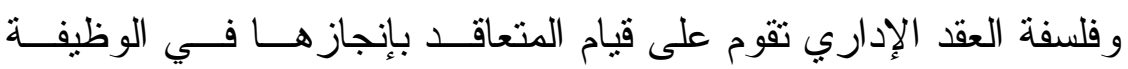
الإدارية على نحو ما يرسمه العقد المبرم بينه وبين جهة الإدارة لذلك فإنه و إلـى جانب الحق الذي تتمتع به الإدارة في اقتضـاء موضوع العقد تتتتع فيــهـ الإدارة صاحبة التعاقد وصاحبة المناقصة بسلطات تقديرية واسعة مستمدة من القـانون الدستوري و القانونية في تنظيم و إدارة المر افق العامة و التي هي محسـور نــشاط

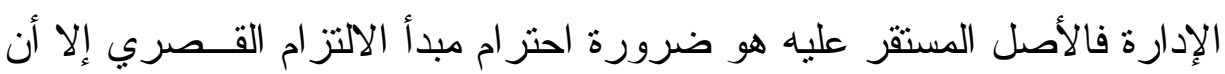
من مقتضى مبدأ سير المر افق العامة أنه يجوز النزول عن شرط من شــأنه أن يحل الجهة الإدارية من سلطاتها الأساسية تجاه المتعاقد في تعديل العقــــــــاءً أثناء تتفيذه أو عن تجديد العقد لتعلقها بالنظام العـام (') فــإن اســتعمال الإدارة

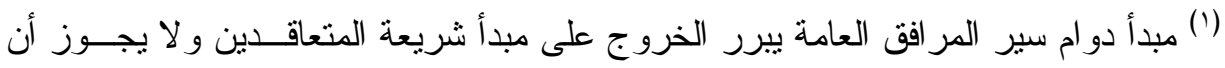

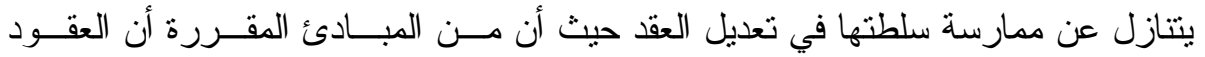

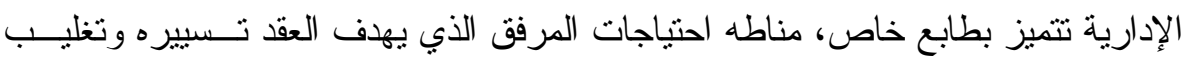
وجه المصلحة العامة على مصلحة الأفر اد الخاصة، انظر الطعون للمحاكم المصرية:

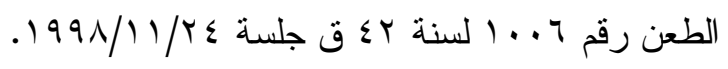

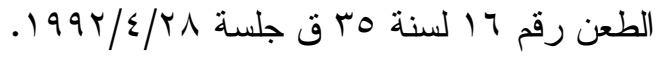

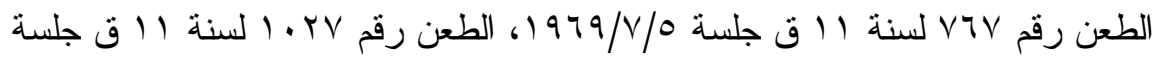

$$
.19 \vee N / 1 / Y \Lambda
$$

الطعن رقم 199V///Y0

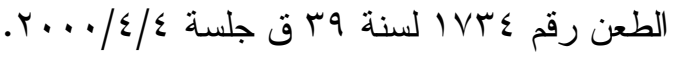


سلطاتها الأخرى بقاعدة بأن العقد شريعة المتعاقدين (') كما أكدت هــذا المعنـى

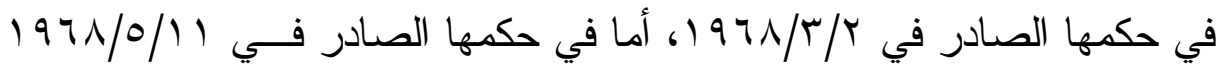
فقد قالت أن تعديل العقد الإداري أمر تملكه الإدارة المتعاقدة علــى أن تعــوض المتعاقد معها عما لحقه من ضرر نتيجة هذا التعديل. وهناك حكم آخر صدر من محكمة القضاء الإداري المصري الصادر في

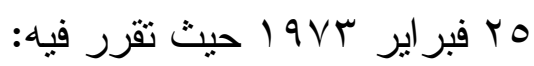
"إن العقود الإدارية تتميز بطابع خاص، مناطه احتياجات المرفــق الــذي يستهدف العقد تسييرة وتغليب المصلحة العامة على مصلحة الأفــر اد الخاصـــة، و هذه الفكرة هي تحكم الروابط التي تتشأ عن العقد الإداري، ويتسنى هذه الفكرة أن للإدارة سلطة إنهاء العقد، كما أن لها سلطة تعديل العقــد بحيــث لا يــصل التعديل الذي يخل بتو ازنه المالي (r)، و هنالك فتوى أنها تعترف فيه حــق الإدارة لسلطتها في تعديل العقد الإداري بإر ادتها المنفردة كلما اقتضت حاجــة المرفـق هنا التعديل على خلاف ما ينص عليه العقد على حق السلطة تعديل العقد أثتـــاء

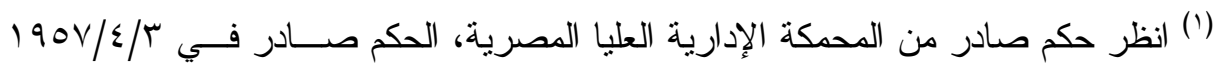

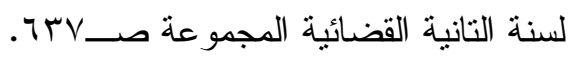

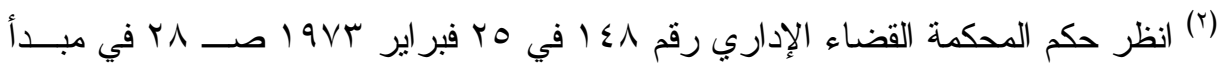

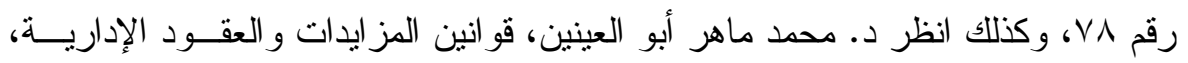

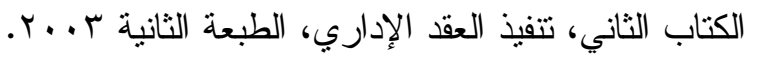


تتفيذه وتعديل مدى التز امات المتعاقد معها، على نحو وبصورة لم تكن معروفــة

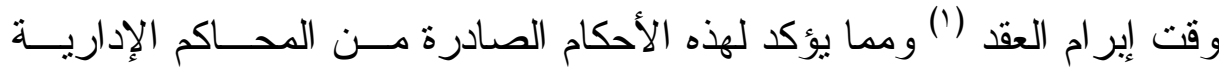
المصرية حيث أجازت المادة (V^) من اللائحسـة التنفيذيــة للقــانون 19 لــــنة 1991 بشأن المناقصات و المز ايدات لجهة الإدارة حق تعديل حجم عقودها زيادة أو نقصا في حدود بro\% بالنسبة لكل بند بذات الثروط و الاسعار ، ولكن التعديل منوط بتو افر شروط معينة هي: 1. مو افقة السلطة المختصة على التعديل. r. وجود الاعتماد المالي اللازم للتعديل. r. أن يصدر التعديل خلال فترة سريان العقد. ؛. ألا يؤثر التعديل على أولوية المتعاقد في ترنيب عطائه. ○. بالنسبة لمقاو لات الأعمال فيتم التعاقد على تتظيمها بـشروط أهمهــا أن يكون بطريق الاتفاق المباثر و أن تكون أسعار بنــود المقاولـــة مناســــة و واسعار السوق وشروط مو اققه السلطة المختصة.

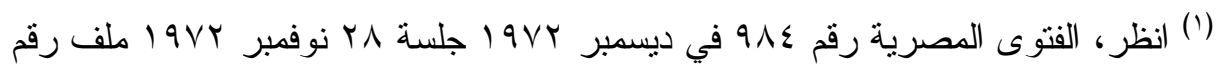
ا 
موقف القضاء الكويتي من سلطة الإدارة فــي تعـديل العقــود الإداريــة

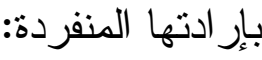

تؤخذ الأحكام المتعلقة بالعقود الإدارية بالأحكام الخاصة بهــذه العقـود،

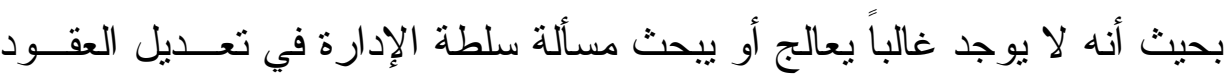

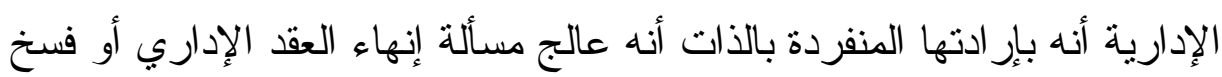

أما من حيث القانون الكويتي يرتبط بمدى للسلطة الإداريــة فــي تعـديل العقود بإر ادتها المنفردة، فالقانون الكويتي لم يتطرق لهذه المسائل وذللك باعتبــار

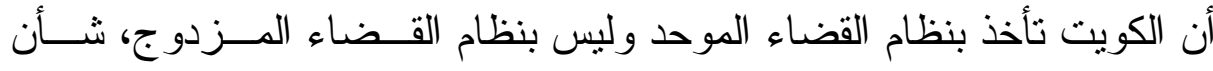
الكويت في ذلك شأن سائر البلاد الني بطريق النظام ما عدا القـــاء العدـاني

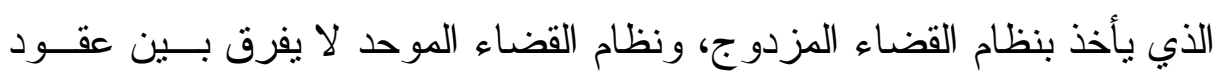

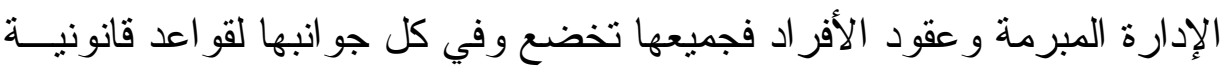

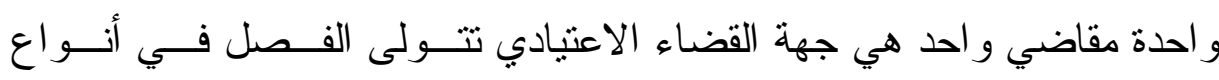

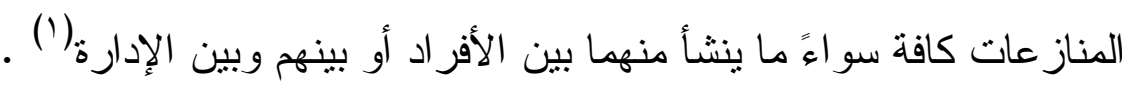

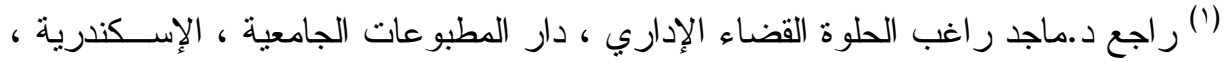

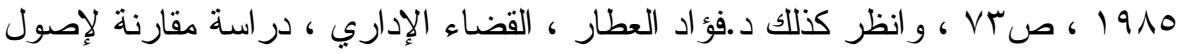

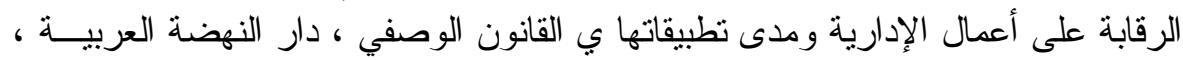

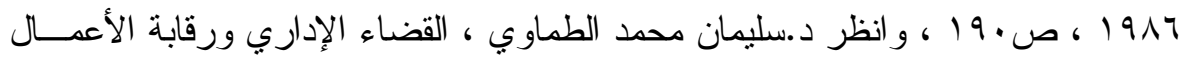

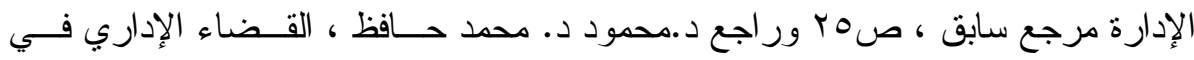

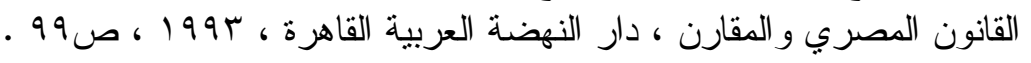


و عليه فإن سلطة الإدارة صاحبة التعاقد الإداري في تعديل العقود بإرادتها المنفردة بحيث إنها لا تملك في مو اجهة المتعاقد معها من حقوق إلا تلـــــ التــي ينص عليها العقد أو تقضي بها قو اعد القانون الخاص وبعض الاستثاءات التـي وردت بها نصوص خاصة بالعقود الإدارية تتصل بمجملها بإبر ام العقد لا بتنفيذه أو إنهائه، ولذ فإن القاضي في ظل هذا النظام يرد مناز عات العقود، أيا كانـــ،

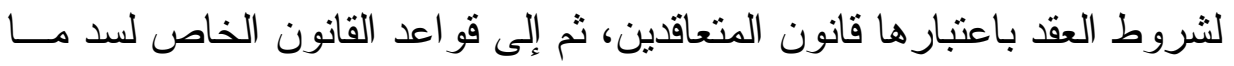
عسى أن يكون بها من نقص، واستشهـ على ذلك بالقانونين الفرنسي و المصري قبل أن يوجد في كل من البلدين قضاء إداري . ونحن من جانبنا نرى أن فكرة الربط بين الأخذ بنظام القضـاء المـزدوج ووجود أحكام خاصة بالعقود الإدارية تميزها عن العقود المدنية وما يقال فيهــا أنها تعتبر النتيجة هي السبب، أي أن وجود جهتي القضاء هو السبب في وجـود

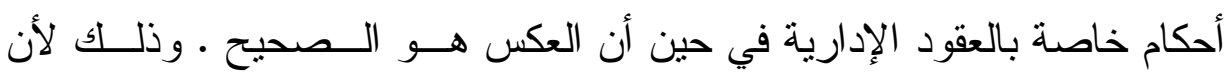
وجود العقود الإدارية بمضمونها المميز إلى جانب العقود المدنيــة يرجـع إلـى طبيعة هذه العقود وتعاظم دور ها في ممارسة الإدارة لنشاطها باعنبار ها من أهم وسائل ممارسة هذه النشاط في مجال تتظيم و إدارة المر افق العامة، و الذي يعتبر 
من أهم مبرر ات وجود الإدارة وما تسعى إلى تحقيقه من أهداف و إلا وهو خدمة

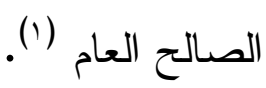

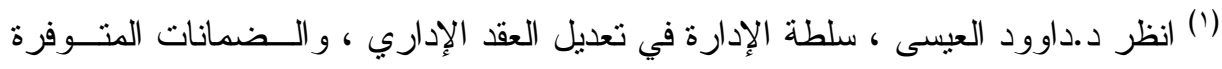

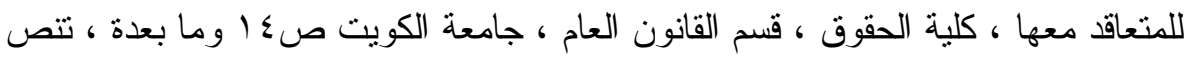

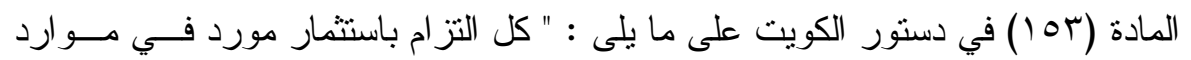

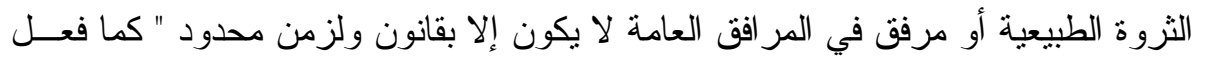

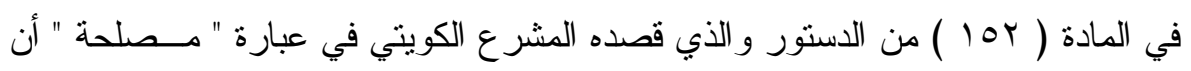
يترك للحكومة ( الإدارة الحكومية ) صلاحيات واسعة في مجال التنظيم الإداري وبالعكس

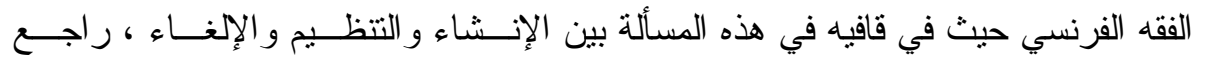

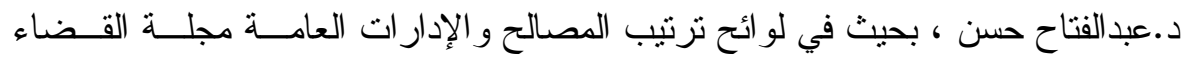

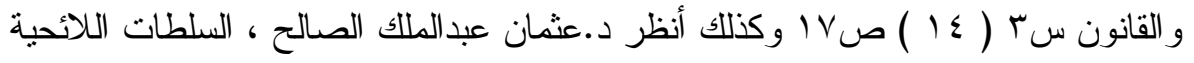

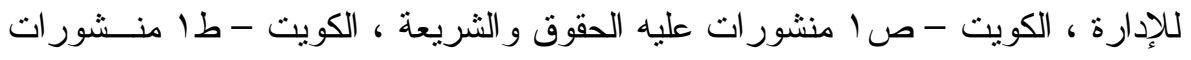

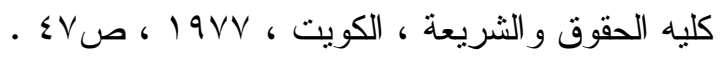




\section{المبحث الثالث}

\section{الضمانات المتوفرة للامتعاقد هن سلطة الإدارة بعد إعطاءها الحق في تعديل العقد الإداري بإرادتها المنفردة}

يلقى العقد الإداري على عاتق المتعاقد ( المناقص الفائز بالمناقصة ) بعد التزسية عليه و إثنعاره بإبر ام العقد مع الإدارة و اجباً بأداء التز امه التعاقدي بنفسه وفي المو اعيد المتقق عليه و التي تعتبر من القو اعد العامة في العقود الإداريــة، ومن ثم يكون تتفيذ هذا الالنز ام و اجباً حتى ولو لم بنص عليه مر اجعة في العقد،

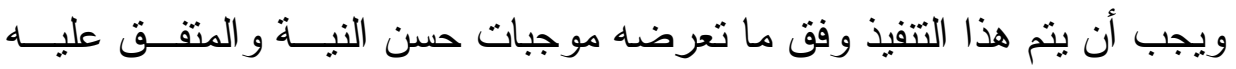
بالعقد أو وفاتر الثروط (') وقد قضت المحكمة الإدارية العليا المصرية بالقول " من المسلمات لأن يقوم المتعاقد بنفسه بالتنفيذ، فالتز امات المتعاقد مع الإدارة مع الإدارة التز امات شخصية، لا يجوز لله أن يحل غيره فيهــا (؟)، ويـستمد تلــك

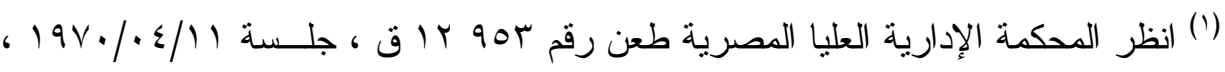

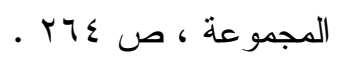

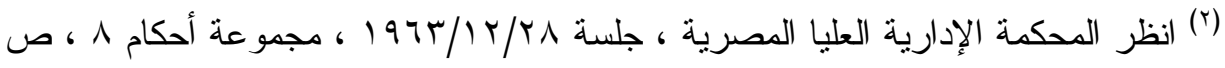


القاعدة مصدر ها من طبيعة العقود الإدارية، و التي يلتزم فيها المتعاقد مع الإدارة بأن يكفل سير المر افق العامة بانتظام و اضطر ار و عدم تعـريض هـــا الـسير المستمر و المنتظم للخطر (') - (') للمتعاقد مع الإدارة حقوقاً تقابل ما سبق و أن أوفي به من التز امات، قلـــــ من الحق في اقتضـاء المقابل المالي للعقد، وضمان توازنه المالي، إضــافة إلــى حقه في الحصول على تعويض إن كان لـــللك موجبــاً (؟) و لا يجـوز لــلإدارة التحليل من التعقد بعد إتمام إبر امه .

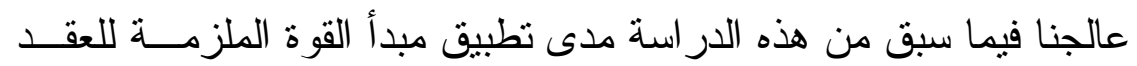

بالنسبة للعقود الإدارية، ور أينا كيف أن الإدارة تتبع بسلطات كثيرة في مواجهـة

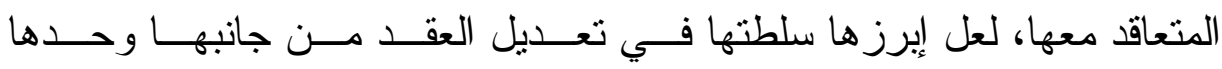

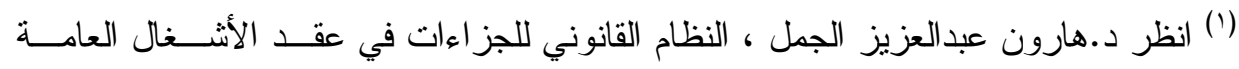

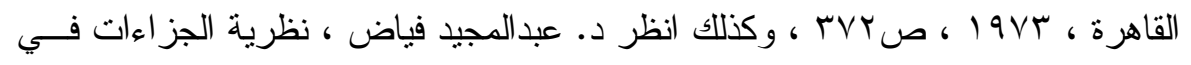

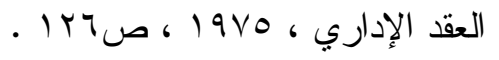
(r) انظر د. عبدالعزيز عبدالهنعم خليفة ، الأسس العامة للعقود الإدارية ، دار الكتب القانونية،

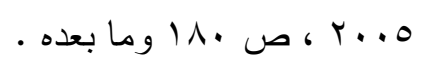

مجلت البحوث القانونيتوالإقتصاديت ع ؛ 
بإر ادتها المنفردة إذا استـدعت مقتضيات المرفق العام ذلــك تحقيقـــاً للمــصـة

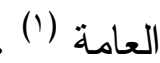

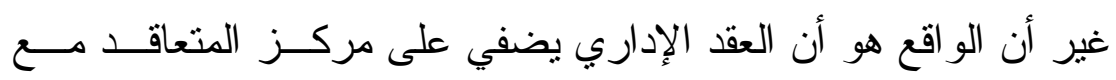

الإدارة طابعاً يميزه عن مركز المتعاقد في القانون الخاص ـ فإذا كان من حـق

المتعاقد مع الإدارة أن يطالبها بتتفيذ التز اماتها على النحو الذي نص عليــه فـي

العقد، فإنه قد يمتتع عليه هذا، وذلك حيث ترى الإدارة أن حسن ســير المرفـق

العام وملاء منه للنطور ات الجديدة تقتضي تعديل الثروط التــي نــص عليهـــا

ولما كان من المتفق عليه أن للإدارة سلطة في تعديل العقد الإداري قــلا

يجوز و الحالة هذه، أن بقف المبدأ عند هذا الحد، و إلا استخدمت العقود الإداريــة

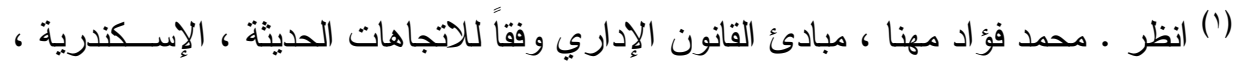

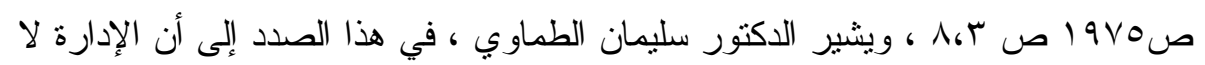

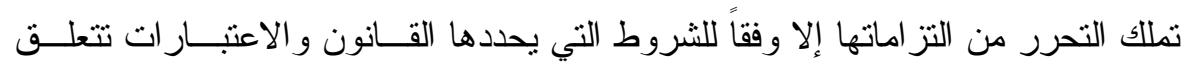

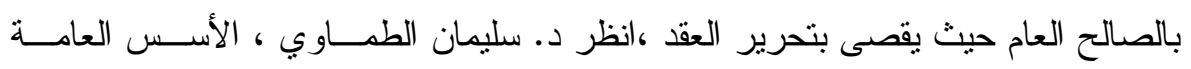

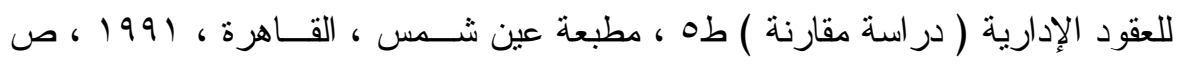
OOV

Lau badere - Venezia Wt GAudmet. Y. Traitedes droit Administratif.L.G.D.J.Paris , 1995 , P. 638 els.

مجلت البحوث القانونيت والإقتصاديت بـ 
على عنصر مناف للعدالة، ولما تقدم أحد للتعاقد مع الإدارة مادام مهــدداً بــذلك التعديل الذي يزيد من التز اماته ـ خاصة وأن المتعاقد مع الإدارة لا يتعاون معها مجاناً، و إنما يهدف من ور اء تعاقده معها إلى الاستفادة من ذلك .

ولذا فإن المتعاقد مع الإدارة يملك، في مو اجهــة ســلطة التعــديل التـي

تملكها الإدارة، وسيلتين لضمان حقوقه الأولى استحقاقه للتعويض عن ما يـسببيه التعديل من أضر ار • و الثانية حقه في طلب فسخخ العقــــ اذا كــان مــن نتيجـــة التعديل جعل تتفيذ العقد باهظ التكــاليف بــالنظر لإمكانــات المتعاقــــ الماديـــة و الفنية، وهذا سوف نتاقش هذه الوسيلتين في المطلبين الأول و الثاني مــن هــذا المبحث

\section{المطب الأول}

\section{حق المتعاقد في التعويض مقابل التعديل للهقد الإداري}

Le droit du Co - Contractant a une indemnité Com pensatrice en Face du pouvoir modificateur

بموجب حق الإدارة المتعاقدة و التي تتمتع بسلطات تقديرية واســعة فـي تعديل شروط وبنود التز امات المتعاقد باير اداتها المنفردة وفقاً للعقــود الإداريــة 
وفي المقابل من نتيجة ذلك التعديل مما ترتب عليه في كثير من الأحيان زيــادة الأعباء المالية على عاتق المتعاقد الأخير المناقص أو التاجر الفـائز بالترســية المناقصة بعد إثتعاره بالمناقصة و إير امه بشروط وبنود العقد .

بحق أن يقال هنا فليس من الإنصاف و العدل أو حتى المصلحة المتبادلـــة بين الجانبين وفقاً لمبدأ الإيجاب و القبول و إبر ام الر ابطة التعاقدية على الرغم من

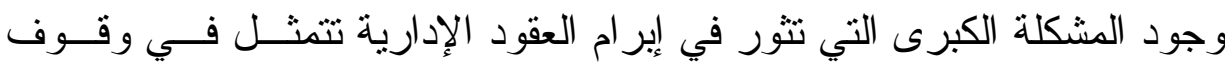
الإدارة باعتبار ها سلطة عامة تتمتع بامتياز ات خاصة في مو اجهــة الفــرد و أن العقد الإداري عقد تعاون بهدف إلى استقطاب المعـاونين الـــين (') تحتــاجهم الإدارة و هذا التعاون يقود إلى الاعتر اف للمتعاقد مع الإدارة بالحق في سلطة في التعويضات (r) ولذا فقد اعنرف القضاء الإداري بحق المتعاقد مــع الإدارة فـي

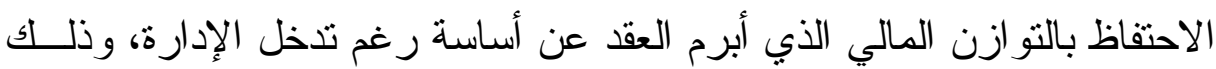

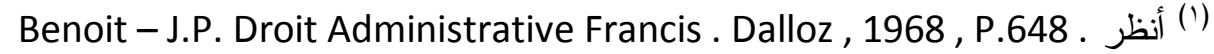

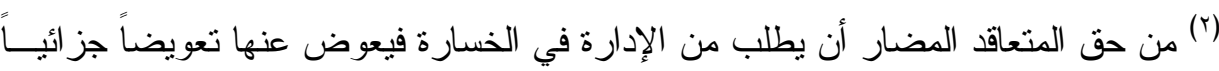

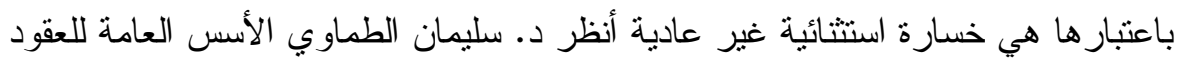

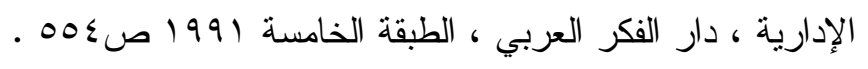

مجلتً البحوث القانونيت والإقتصاديت 
بمنحة تعويضاً عن الأضر ار التي تكون لحقته في مركزة التعاقدي وذلــك وفقــاً

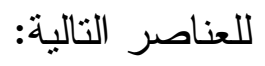

\section{العنصر الأول : مبدأ التوازن المالي للعقد :}

Le péricope d'équilibre financier du contact administratif:

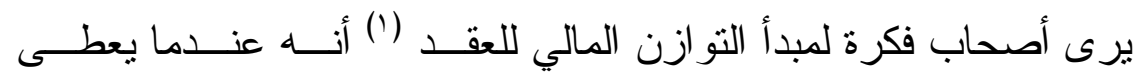

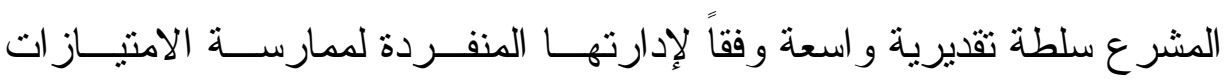

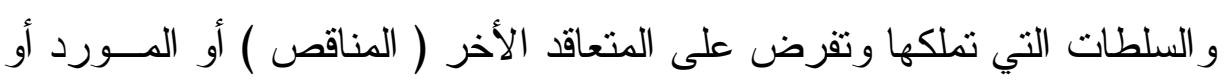

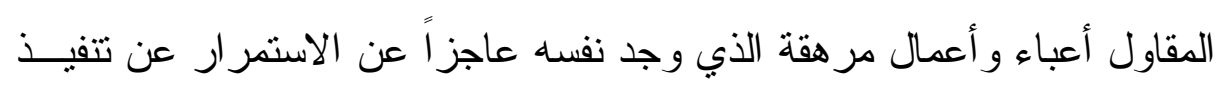

(') يختلف مفهوم التوازن الاقتصادي للعقد عن التو ازن المالي للعقد الإداري فالأخير يعطـيـي

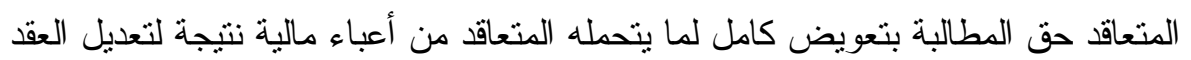

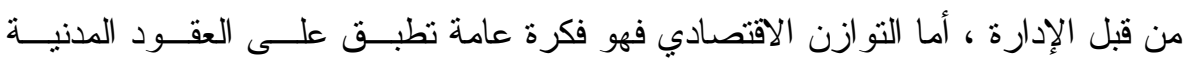

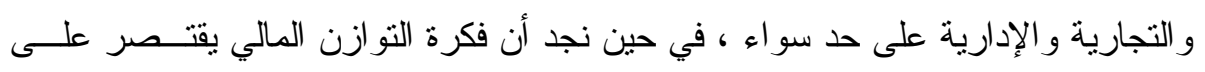

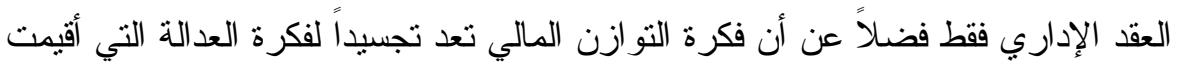
على أساسها نظريات عمل الأمير و الصعوبات المادية غير المتوقعة ، و هي تمنح المتعاقد

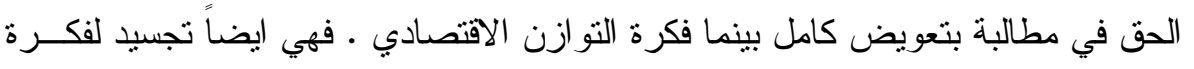

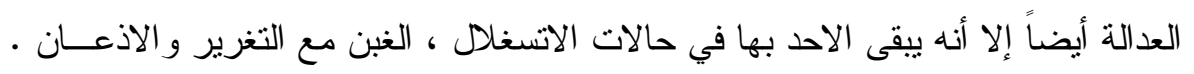

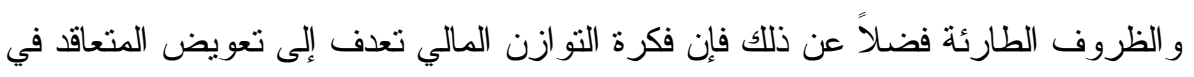

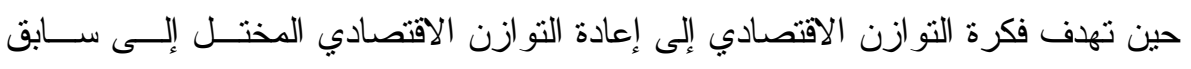


شروط وبنود العقد الذي اتفق عليه الطرفان بالإيجاب و القبول منذ الإدارة هـي

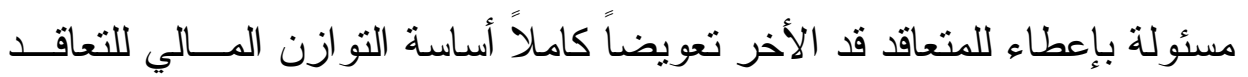
ومسئوليتها بدون خطأ في التعويض، وذلك من طبيعة العقــــ الإداري أن يقـيم بقدر الإمكان نوازناً بين الأعباء التي يتحملها المتعاقد مع الإدارة وبين المز ايــا التي ينتفع بها فإذا ما أدى تدخل الإدارة إلى الإخلال بهذا التوازن كما حدد فـي

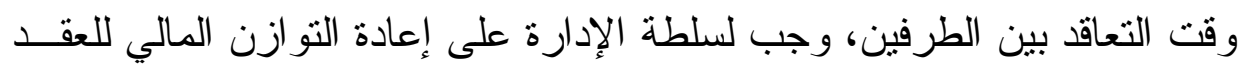
الإداري إلى ما كان عليه وقت إلرام العقد المتفق عليه الطرفان وفقاً لمبدأ القبول و الإيجاب وتجرى فيه وفقاً لدفاتر الثروط على النص على هذا الحق و الذي فيه

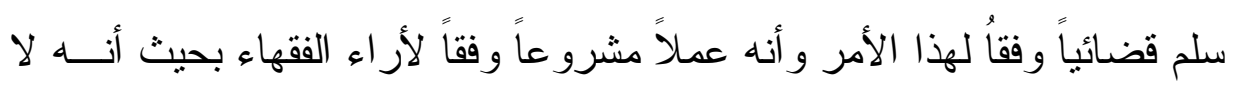

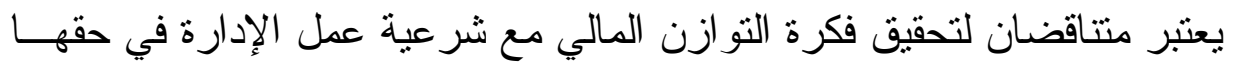
بسلطة تعديل العقد (') بعنر ملان وفي مجال فكرة التو ازن المالي للعقد فإن الإدارة ملزمة بالحفــاظ علـى التو ازن بما يحقق هدف العقد الإداري الأسمى وهو الحفاظ على المصالح العليــا

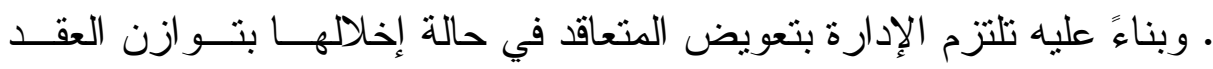

(1) الحفاظ على النو ازن المالي للعقد مرجعة العدالة وما يتعين أن يكتيف تتفيذا العقـــود الإدارة

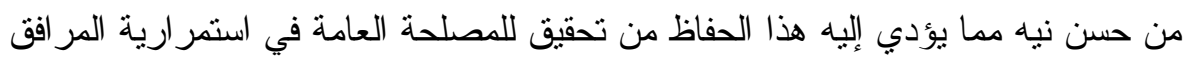

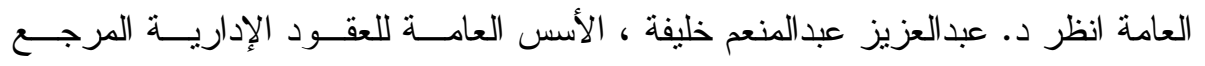

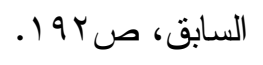

مجلت البحوث القانونيت والإقتصاديت وب ع 
المالي، علماً أن هذا التعويض لا يستتد إلى خطأ، لذا ينبغي التعرف على نظرية عمل الأمير ونظرية الظروف الطارئة التي بموجبها يحق للمتعاقد طلب الفـسخ دون خطأ من جانب الإدارة . - من

العنصر الثاني : نظرية فعل ( عمل ) الأمير:

\section{Le théorie du fait du prince:}

فعل الأمير تقصد فيه في المقام الأول هو عن كل عمل مشروع يصدر عن سلطة (عامة ) التأثير عن التزامات المتقاعد مع الإدارة ويكون من شأنه زيادة أعباء المتعاقد في تتفيذ التزاماته التي ينص عليها العقد، وهذا الإجراء قد يصدر في السلطة الإدارية المتعاقدة أو من سلطة أخرى في الدولة وقد يتخذ هذا

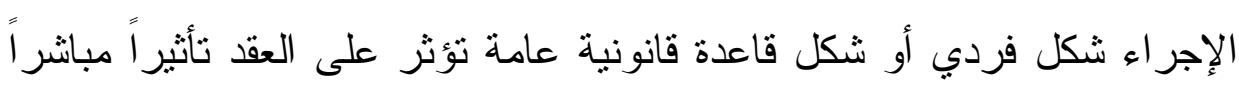
مما يزيد من أعباءة يتزتب عليه وجوب تعويض المتعاقد عما يلحق به تعويضاً

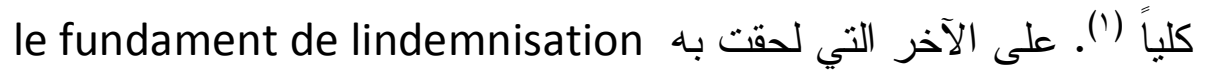

G.vedel , وكــنلك انظـــ De laubdére , op.cite , no.867 انظر تعريف النظرية Droit Administrative d , 1980 , 1034 وأنظر سليمان الطمــاوي الأسـس العامــة

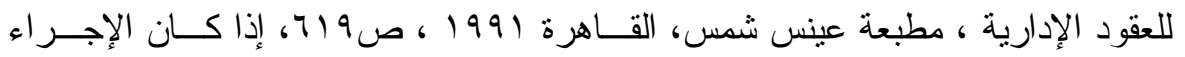

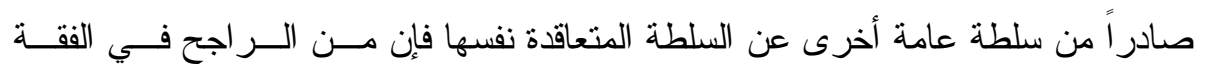

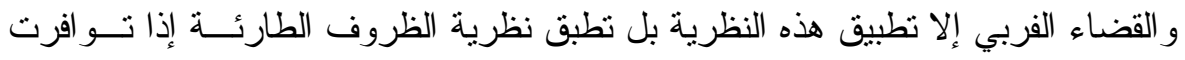
شرط هذه النظرية .

مجلت البحوث القانونيت والإقتصاديت ؛ ؛ 
و الجدير بالذكر هنا بأن بعض الفقهاء قد اختلفوا حول ما هو الأساس أن

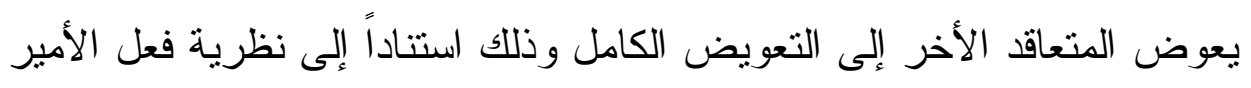
فنهم من ذهب في رأية وفقاً للأمور التالية :

\section{[ أولاً ] المسئولية على أساس الخطأ من قبل سلطة الإدارة :}

\section{La re's ponsanilité pour faute:}

الإدارة المتعاقدة مسئولة مسؤولية كاملة عن ما نسببه للمتعاقد الأخر من

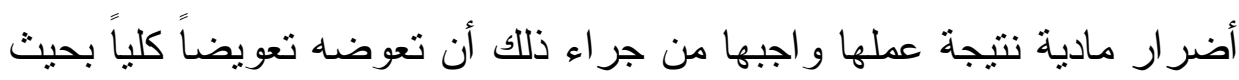
تتيح للمتعاقد المطالبة بالتعويض إجر اءات مشروعة في ذاتها سو اءً أصدرت من الجهة المتعاقدة تمارس سلطتها وفقاً لإر اداتها المنفردة في تعديل العقد أو صادرة من سلطة أخرى (') يجب أن يكون العمل الصادر عن السلطة العامة عملاً مشروعاً ليس فيه خطأ لأن التز ام الإدارة بالعقد الإداري لا يمنعها من ممارسة سلطاتها الإدارية في تتظيم وتسيير المر افق العامة ونحن نرى هنا أن مسئولية الإدارة هنا ليست مسئولية تعاقدية لأن الأجر اء المتخذ هو الأجر اء سليم و إن كان

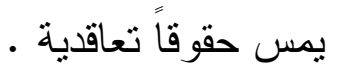


على الرغم هناك انتقادات بشأنها وفقاً لهذه الفكرة فإن فكرة المسئولية على أساس الخطأ مستبعدة فالإدارة تعوض الأفر اد وفقاً للمخاطر وظروف معينه في الأضر ار في قانون المناقصات العامة التي لحقت بالمتعاقد (') . [ ثانياً ] [الإثراء بلا سبب :

\section{La théorie de l'enrichissement sans cause}

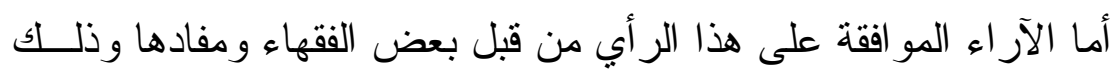

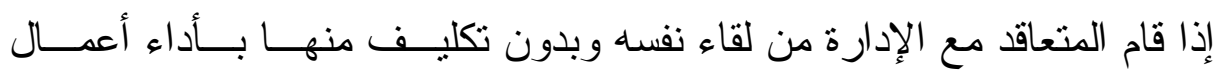
وخدمات إضـافية غير منصوص عليها بالعقد، يكون لهذا المتعاقــــ الحـق فـي مطالبة الإدارة بتعويض عما أنفقة من تكاليف ومصاريف للقيام تبعت الأعمــال أو أداء خدمات وهذا الأمر شبيه بإصدار أو امر تغييرية في قـانون المناقـصات

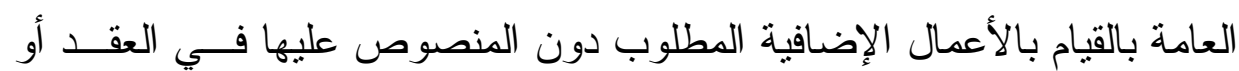
النسبة المسموح بها تسلك الأعمال و المدونة بالعقد شريطة أن تكون هذه الأعمال

(') وير اعي القاضي عند تقديم التعويض في حاجة الخطأ المشترك بين الإدارة و المتعاقد معها

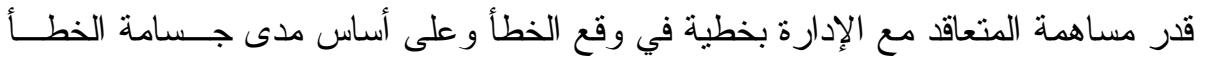

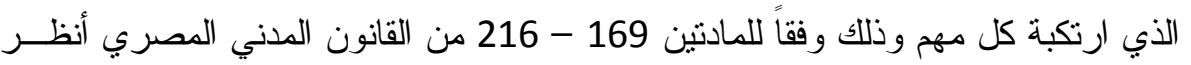

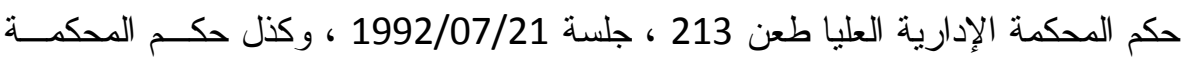

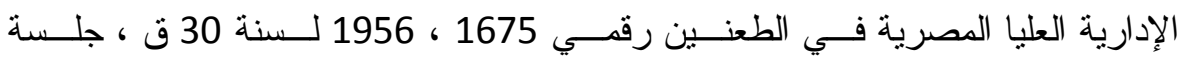

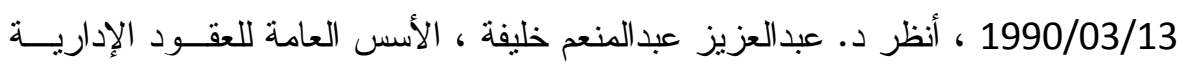

$$
\text { المرجع السابق ، ص190 - (19) }
$$

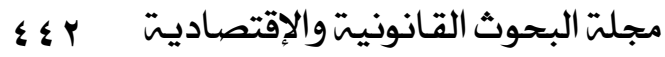


أو الخدمات الإضافية ذات فائدة و لازمة للمرفق العام وقد حققت فيه المــصلحة

العامة، وذلك على أساس قاعدة الإثر اء بـلا سبب ('). و أن هــذه الفكــرة كانـــ

بدورها موضع نقد فقد أخذ عليها أنها تربط بين تعويض المتعاقــد مــع الإدارة و إثز اء هذه الأخيرة على حساب المتعاقد .

\section{] : ثالثاً ] نصوص العقا :}

\section{Les clauses contractuelles:}

حيث يرى فيه بعض الفقهاء في أصول العقد الإداري بأن مصدر التزام سلطة الإدارة يتعهد بموجبة طبقاً لهذه النصوص القانونية للعقد والمتقق عليه الطرفان قبو لاً و إيجاباً بالتعويض على اعتبار بأن المتعاقد مع الإدارة لم يتعهد في العقد إلا بالقياس في محل ثابت بالذات و على أساس سبب محدد و أنه لم يقبل تحمل بعض الالتز امات و التي قد تكون باهظة و أعباء ثقيلة على كاهله إلا مقابل تعويض معين (r) وهذه الفكرة تكون صحيحة إذا كانت تصلح كأساس بتدبير

(1) انظر حكم المحكمة الإدارية العليا في الطعن رقم 562 لسنة 23 ق جلسة 1978/04/01

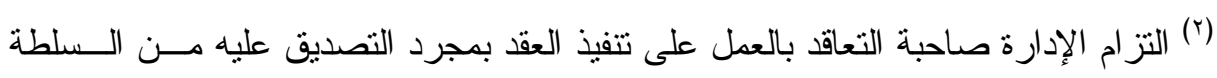
المختصة واحتر امها للعقد ككل ، المزيد من التفاصيل انظر د. ابر اهيم محمد على ، أثنار

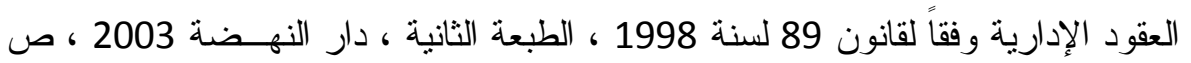

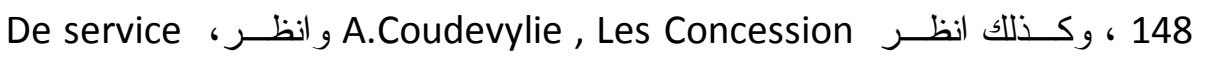
public des collectivités local , 1983 , p. 54 
التز ام الإدارة المتعاقدة في حالة تعديل العقد الإداري بالإدارة المنفردة وحدها

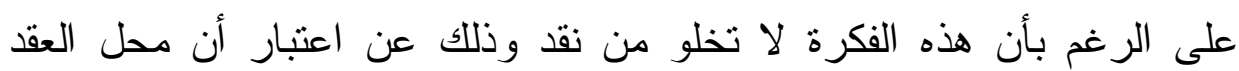

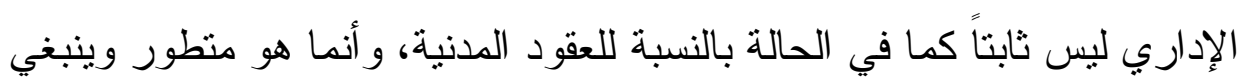
أن يساير المقتضيات المستجدة وسريع النطور بالنظر لها تحيط بها من ظروف بالمقارنة مع فروع القانون الأخرى • [ رابعاً ] مبدأ المساواة أمام الأعباء و التكاليف العامة :

\section{Les principe dé Légalité devant les charges publiques:}

بموجب هذا الر أي و الذي ذهب إليه الفقهاء على أساس مسسئولية الإدارة

عن التعويض تكون وفقاً لمبدأ المساو اة بين الأفراد دون أي تميز بينهم باعتبــار

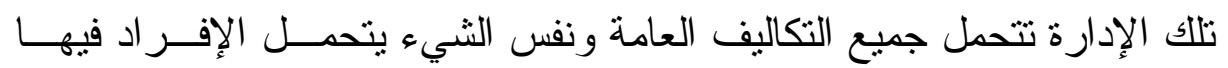

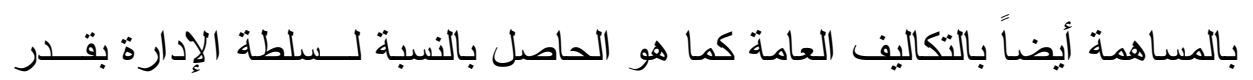

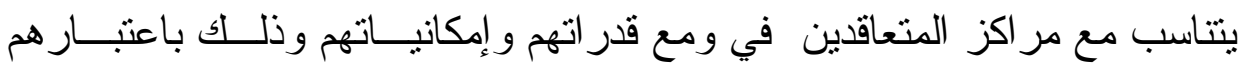
يساهمون في نشاطهم مساهمة خاصة وبالتالي بأن هذا المبــــأ يــصلح أساســاً للتعويض للإفر اد و المتعاقدين مع سلطة الإدارة للتعويض للجميع بدون إلى تفرقة

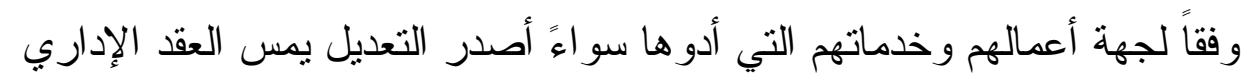

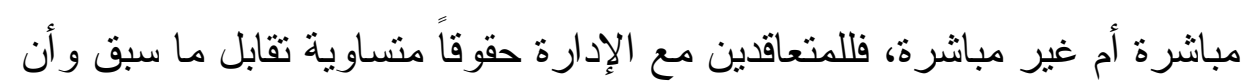
أو في به من التز امات فله حق في اقتضـاء المقابل المالي للعقد وضمان نوازنـــهـ

مجلتّ البحوث القانونيت والإقتصاديت ؟ ؛ 


\begin{tabular}{|c|c|}
\hline أ.د / فؤاد نصر اللَه عوض & العدد هه ( ابريل عا.r ) \\
\hline
\end{tabular}

المالي إضافة إلى حقه في الحصول على تعويض إن كان لذلك موجباً (') علـى الرغم بأن عدم المساو اة يعطى الإدارة الامنياز ات و السلطات في مجــال إبــرام العقد وتتفيذه وتعديل العقد و إعفاءه بإر ادتها المنفردة . الشروط العامة لتطبيق نظرية فعل الأمير: Les Conditions Générales de l'applications de la théorie du fait prince:

تطبيق نظرية فعل الأمير بشرط أن تخضع المتعاقد مع الإدارة لكي يحصل على التعويض لشروط عامة هما : الثرط الأول : أن يتصل الإجر اء بعقد إداري: IL faut que la contractait été modifie:

الثرط الثاني : أن يكون إجراء التعاقد من أعمال السلطة العامة : IL faut que la masure prise ait été emne d'un autorité pibloque:

(') وتستمد هذه القاعدة مصدر ها من طبقة العقود الإدارية و التي تلتزم فيها الإدارة المتعاقـــة

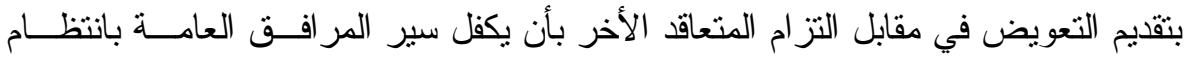
و اضطر ار وعدم تعريف هذا السير المستمر والمنتظم للخطر انظر د. عبدالمجيد فياض ، نظرية الجزاءات في العقد الإداري ، القاهرة ، 1975 ، ص ـ 126 
تعتبر هذا الثروط الأساسية لتطبيق نظرية فعـلـ الأميـر حيــث يجــب فيه أن يكون الإجر اء لتعديل العقد الإداري و الذي قام فيه هذا الأجر اء ويـسبب ضرراً كبيرًا للمتعاقد الأخر ( المناقص ) عملاً من أعمال السلطة العامة ســو اءً

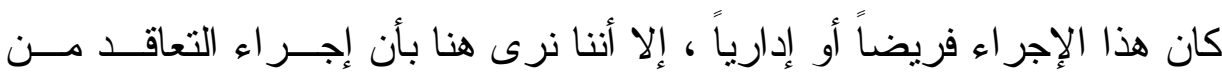
أعمال السلطة العامة إنما هي لا تطبق عن نظرية فعل الأمير بل على نظريـــة الظروف الطارئة مقاصة بعد إبر ام العقد وخلال مرحلة تتفيذ تحــدث ظــروف استثنائية عامة غير متوقعة في شأنها أن تجعل تتفيذ الالتز ام العقد اثد إر هاقــا،

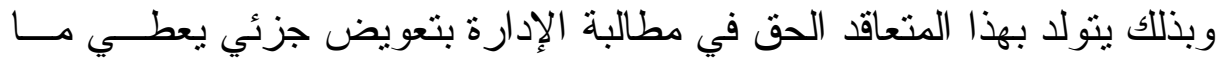
إصـابة من خسارة، تكاد و لا تخلو مصـادر القانون الإداري مــن ذكــر نظريـــة الظروف الطارئة (') لقد خرج القـــاء الإداري عــن قاعــدة إلز اميــة العقـــ للمتعاقدين استجابة لمتطلبات المصلحة العامة وضرورة إدامــة ســير المر افـق ق العامة، نظر اً التمسك بهذه النظرية من شأنه أن يؤدى إلـى إحجـــام الــشركات و الأفر اد عن إير ام العقود مع الجهة الإدارية وهذا ينعكس بالتأكيد علـى ســير

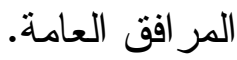

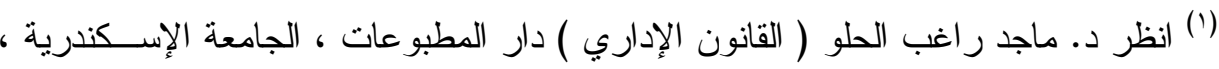

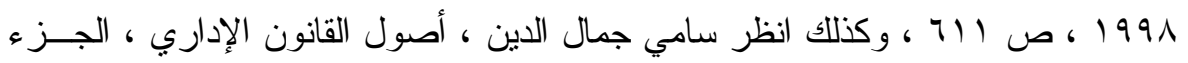

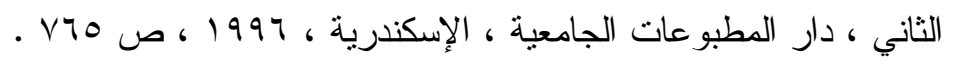




\section{الثرط الثالث : أن يكون الإجراء غير متوقع :}

IL faut que la masure prise ait été improvie:

النأكيد على أن عمل الأمير في عمل إجراءات التعديل على العقد الإداري

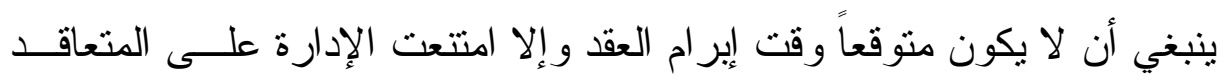

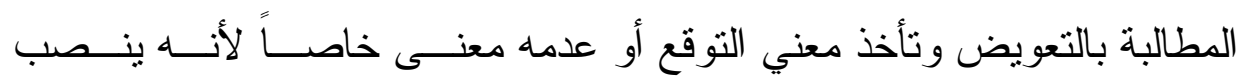
مبانشرة على حق التعديل ذاته، خاصة أن أهم مميز ات العقــــ الإداري مرونتــهـ

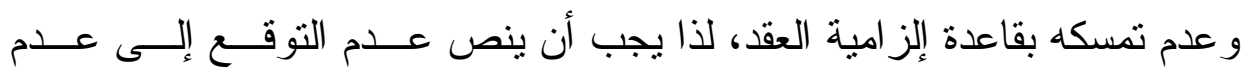

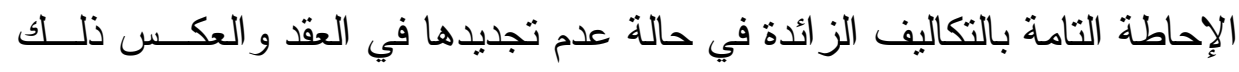
فإذا حددت هذه التكاليف في نصوص العقد لا مجال فيه للمطالبة بتعويض علىى

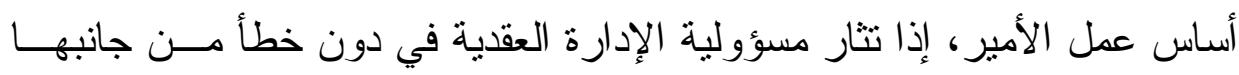

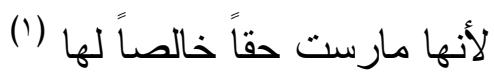

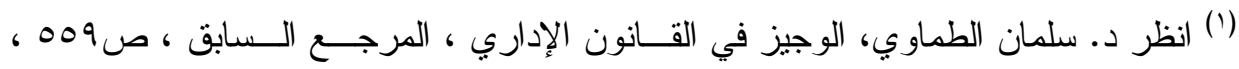

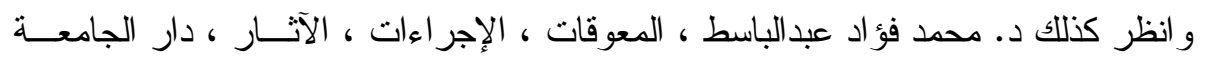

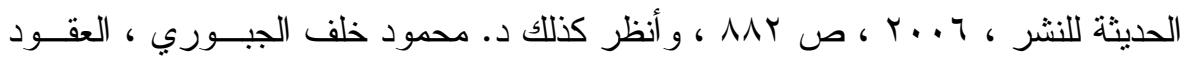

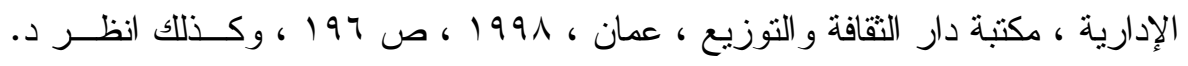

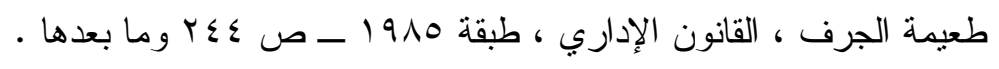




\section{الثرط الر ابع : أن يسبب الأجراء ضرراً فعلياً مع الإدارة :}

IL faut que la masure prise ait été cause un prejudique effeectifeau co - contractant:

إن المتعاقد مع سلطة الإدارة هو شخص يسعى دائهاً لتحقيــق مـــالحة

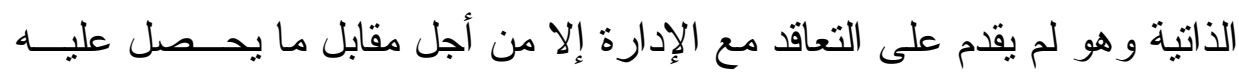

من عو ائد إز اء تقديمه لما هو مطلوب منه في موضوع العقد سواءًكـــان هـــا

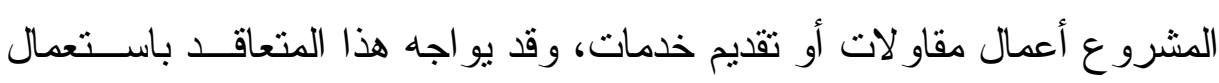

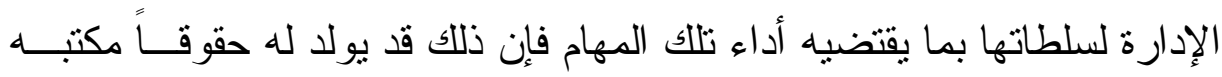

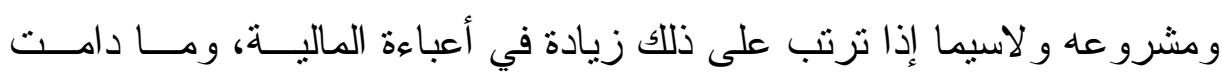

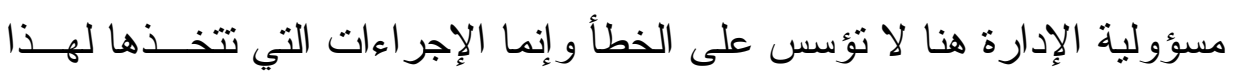
الصدد نتيجة لممارسة سلطتهما في التعديل وفي إصدار قرار ات تتظيمية عامــة

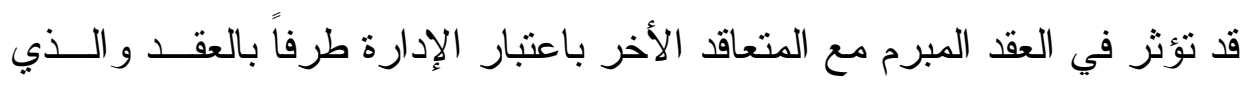
يتصف بالصفة الإدارية بالإضافة إلى ارتباطها بنشاط مرفق عام سو اءً من حيث

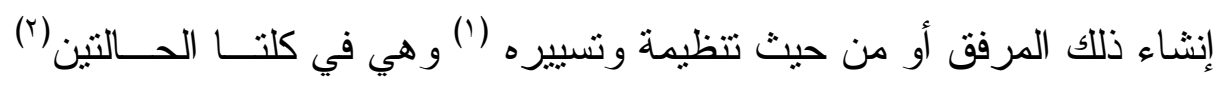

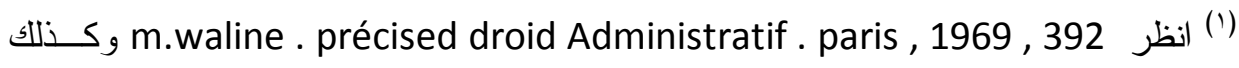

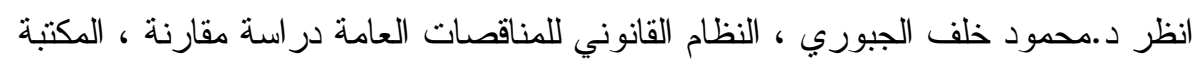

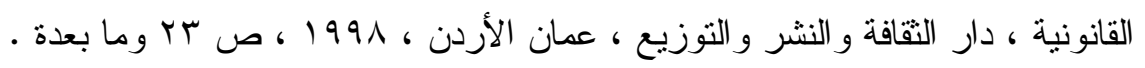

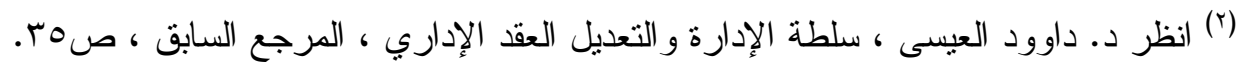


سلطة مثروكة فيتبقي على الإدارة أن يتم للمتعاقد التعويض الكامل إذا ثبت فيــه ضرر فعلي وليس احتمالي • - مرك

\section{[أولاً ] نطاق تطبيق نظرية فعل الأمير :}

L'étendue de L'application ait la théorie du fait du prince:

إذا كان الإجر اء التي تقوم به سلطة الإدارة فـي تعـديل العقــــ الإداري

بإر ادتها المنفردة يستوجب فيه باتخاذ إجر اءات محددة وذللك في ضـــــ نطــاق تطبيق مبدأ نظرية عمل الأمير وأهم هذه التعديلات سواءً تعديل مبانشر للعقـــ أو تعديل غير مبانشر للعقد . ت

(أ) التعديل المباشر للعقد الإداري :

La modification directe du contrat:

التعديل المباثر للعقد الإداري هو التعديل التي تقــوم بــهـ ســلطة الإدارة

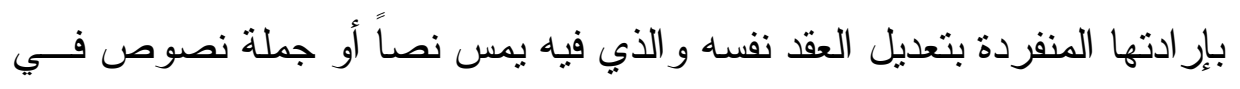

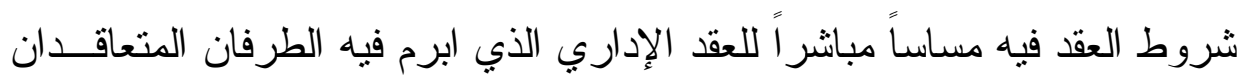
و هذا الإجر اء فردي خاص صادر من الإدارة صاحبة التعاقد للمناقصة و القـصد

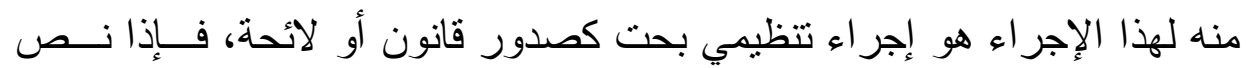

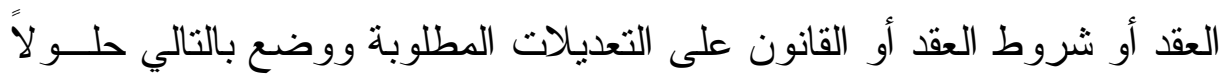




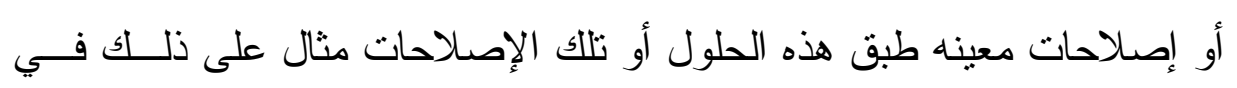

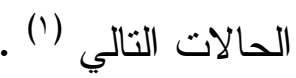

(؟) إدخال تعديلات أو إضافات معينة عن طريق الأو امر التغيرية للمناقصة

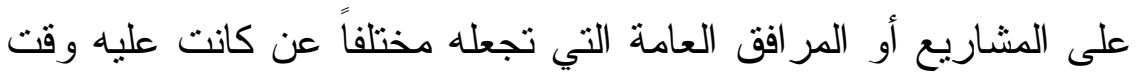

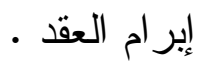

(r) الزيادة أو النقصان في نطاق الأعمال التي تعهد بها إلى المتعاقد المتفق عليه في العقد. (๕)عدم تتفيذ بنود وشروط العقد وذلك طبقاً للشروط الموضو عية لتنفيذه .

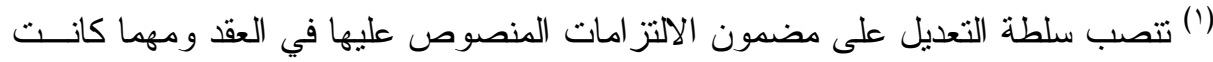

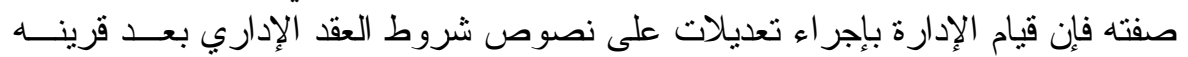

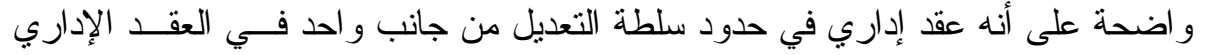

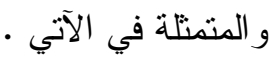

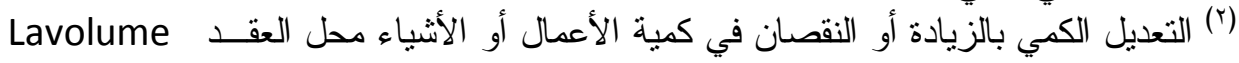
ou La quantify des presentations lesconditions d'execution Le durée التعديل في وسائل وطرق التتفيذ المتفق عليه du contrat

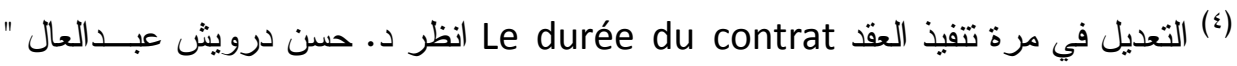

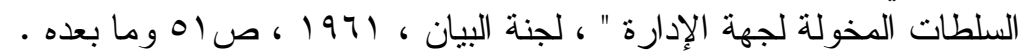

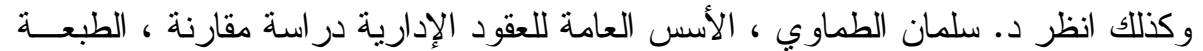

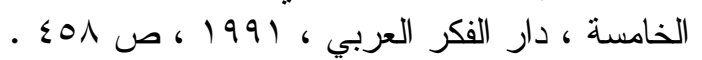

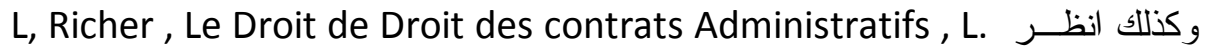
G. D. J , ed 2002 , P. 238 


\section{(ب) التعديل غير المباشر للعقد الإداري :}

La modification indirecte du contrat:

التعديل غير المبانر للعقد الإداري هو نتيجة لتطبيق إجر اء تتظيمي عسام على العقد وهو عكس التعديل المباثر و الذي يقصد فيه تعديل العقد نفسه علـى بنود وشروط العقد طبقاً للشروط الموضوعية لتتفيذه، ولكـن التعـديلات غيــر

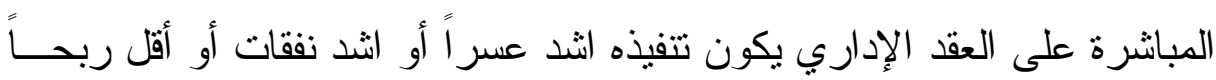
التي تقرق فيه النز امات جديدة ولو ائح الضبط الإداري و الرســوم فــي الــسلطة

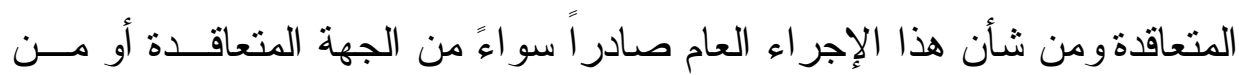
جهة أخرى، ومن نتائج هذا الإجر اء بتعديل العقد الإداري أنه يؤثر بطرق غيــر

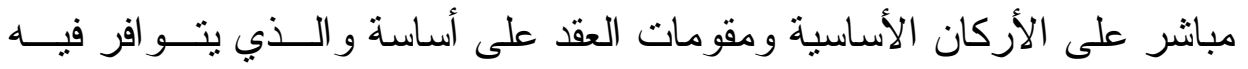
شرط التو افق بين الإيجاب و القبول أي أن القبول إنما يعنى المو افقة على إنـشـاء العقد مبينه على الإيجاب ويترتب عليه تو اجد الإداريين اللازمين لانعقاد العقد . ومن أمتلة التعديل غير المباشر هو إجراء السلطة في شأن هذا الإجــر اء

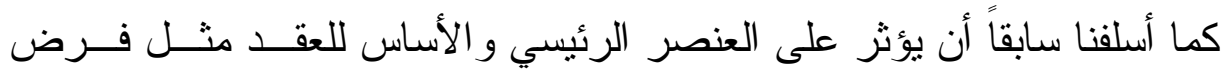
رسوم على المواد الأولية الأساسية بالنسبة لعمل المتعاقد ( المناقص ) أو فرض رسوم على سلطة معينة تؤثر على شروط التعاقد مع متعهد الأصــل بتوريـــها وتطبيعها بالإضافة تطبيق التشريعات الــضريبية أو الجمركيــة أو التـشريعات 
الاجتماعية أو العمالية أو لأسباب سياسية و التي تفرض فيـــه التز امــات جديــدة وعبء كبير ولو ائح الضبط الإداري و الرسوم الإداريــة و الرســوم الإضـــافية

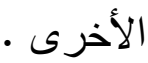

\section{(ثانياً ) أثثار وتطبيق نظرية فعل الأمير :}

Les éffects de la théorie du fait du prince:

تطبيق نظرية فعل الأمير يترتب عليه أثار هامة وغاية الحساسية وقـد

تكون في صالح المتعاقد في حالة تعديل العقد الإداري من قبــل ســلطة الإدارة بإر ادتها المنفردة وذللك في حالة إعادة النو ازن المالي للعقد عن طريق تعــويض

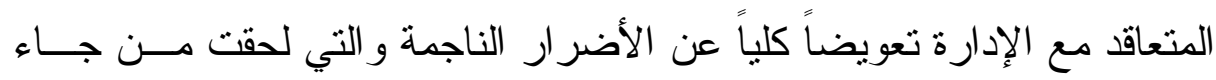
تعديل العقد، ولكن السؤال الذي يطرح نفسه في هذا الموضوع وهو هل يستحق

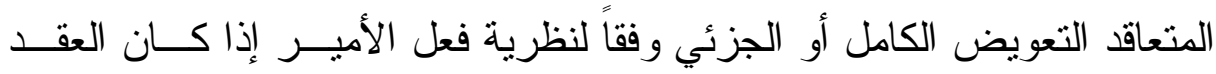
الإداري قد حدد هذا التعويض في حالة تعديله من قبل سلطة الإدارة ؟ و إذا كان

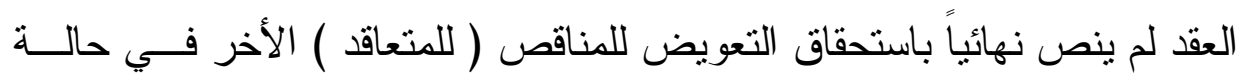
تعديله ؟ ماذا يقصد بالسلطة المتعاقدة ؟ اذا كانت أغلبية الفقة تعترف بالثخصبة القانونية للاولة، فإن الحال لم يكن كذلك فيما مضى، فقد كان يفرق بين الدولـــة باعتبار ها سلطة عامة وبين اعتبار ها شخصي معنوي، وبالتالي فإن الدولة تتكون من عدة أثخاص معنوية تتعدد بتعدد الخدمات التي تؤديها، و عليه فإن كل جهـــة 
من هذه الجهات كانت تعتبر شخص معنوي مستقل وبالتالي يعتبر جهـــة غيــر متعاقدة بالنسبة للجهة المتعاقدة الأخرى، كما أن القضاء توسع في تقسير تعبيـر السلطة المتعاقدة، وطبق نظرية الأمبر إذا كان الأجر اء قد اتخذ من قبل جهـاز من أجهزة السلطة العامة ولو كان هذا الجهاز غير الجهاز الذي تعاقــد، وعليــه

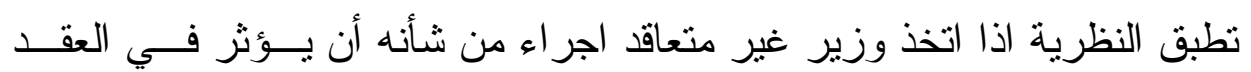
الموقع من وزير آخر (') - من والإجابة عن هذا التساؤل والأي يأخذ في مساره حالتين هما : الحالة الأولِىٍِ إذا كان العقد الإداري قد حدد التعويض

Le détermination de L'Indémnité par le contrat:

غالباً ما ينص شروط العقد الإداري على التعويض الــذي يـسـتحق فيـــه

المتعاقد ( المناقص ) من الإدارة وهذا الثشرط موجــود فــي الــشروط العامــة للمناقصة ( دفتز أو كر اسة الثروط العامة للمناقصة ) أو حتى في شروط العقـــ المبرم بين الطرفان وفقاً لمبدأ الإيجاب و القبول، بتعويض المتعاقد تعويضاً كليــاً

(') المزيد من التفاصيل أنظر د. داوود العيسى ، سلطة الإدارة فــي تعـديل العقــــ الإداري

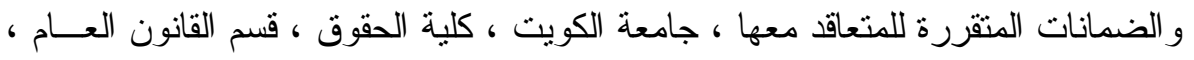

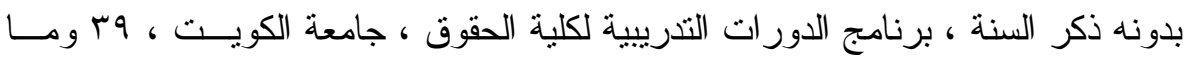


عن الأضر ار الناجمة التي قد لحقت من جر اء إجر اءات التعديل من قبل سـلطة الإدارة وفقاً لشروط تطبيق العقد سواءً لموضوع تحديد التعويض و الذي يشترط فيه قصر التعويض على جزء من الضرر أو استعادة أو المطالبة بالتعويض عن الأضر ار غير المتوقعة وذلك لزيادة الأعباء الجديدة وأدى إلى الإخلال بالتوازن المالي للعقد لصورة خطيرة وجسيمة على العقد المتفـق عليــهـ بــين الطرفــان

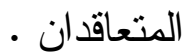
الحالة الثاتية : إذا كان العقد الإداري لا ينص على التعويض: $L^{\prime}$ imdemnisation en L'alesence de tout disposition contractuelle:

وفي الحالة تتطبق بعدم وجود أي نص من شروط العقد الإداري ينص فيه بكل صر احة على تعويض المتعاقد الأخر من قبل السلطة الإدارية أو أنه لم يتوصل الطرفان المتعاقدان إلى أي نتيجة تدل على الإنفاق في كيفية معالجة إعطاء المتعاقد الآخر في حقه في التعويض لجر اء ما أصابه هذا المتعاقد من ضرر سو اءً يكون هذا التعويض كلياً أو جزئياً، وفي هذه الحالة يتولى القضاء في هذه المسألة في مهمة تقدير هذا التعويض ير اعي فيه الكثير من الجوانب بما مدى ما أصاب هذا المتعاقد من اختلال التوازن المالي من أضرار وحتى يكون التعويض كلياً وذلك عن طريق تقدير هذا التعويض من جملة الخسائر التي تكبدها المتعاقد شاملاً النفقات التي من منها دون أن يعوض عنها أو حقه في 
كسب حقوقه المادية من جر اء تقديمه من أعمال وخدمات للمر افق العامة دون أن يتوقعه وفقاً لنصوص العقد، ويتحقق هذا بصفة خاصة في حالة إنهاء العقد قبل ميعاده المحدد وفقاً لأحد نصوص أو بنود العقد المتفق عليه الطرفان

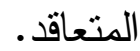

و هناك بعض الحالات الأخرى غير الحالات التي ذكرت و الذب فيه كــان

مبدأ التعويض الثامل و الكلي وهو الأثر الرئيسي لنظرية فعل الأمير و أهمها : [أولاً] المتعاقد الحق له أن يطلب من القاضي فسح العقد إلى وصل الأمــر إلــى طريق مسدود لا فائدة مع الإدارة باعتبار تللك السلطة متعنتة في عمهــا

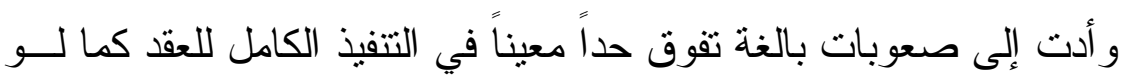
صدر عمل تشريعي يحرم استير اد سلعة ما مع كونها ســلعة ضــــورية

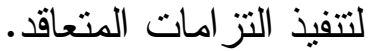

[ثانياً] إذا كان عمل الإدارة يجعل تتفيذ العقد الإداري مستحيلاً، فهذه الاســـحالة

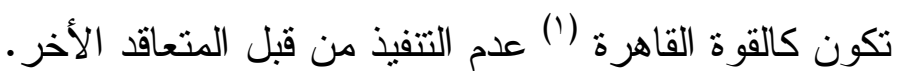

(1) القوة القاهرة حادث ذو طبيعة خارجية ليس لإدارة المتعاقد دخل دفوعة يحول بينه وبـين

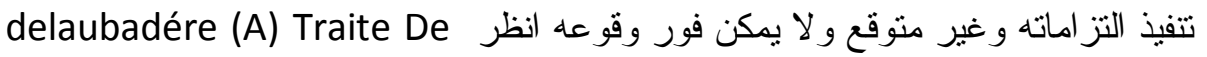
Droit Administratifs .op. cit . p.863

مجلتً البحوث القانونيت والإقتصاديت ه0 ؛ 
[نالثا] يشترط لأعمال نظرية عل الأمير صدور الإجر اء سو اء خاص أو عام من

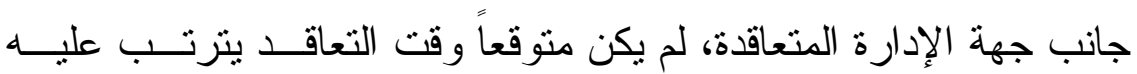
إلحاق ضرر خاص بالمتعاقد فإذا كان في الوسع توقعه وقتتئذ فلا تطبـق النظرية، وتقدير ذلك مما يدخل في سلطة قاضي الموضوع ( '). [ رابعاً ] طلب التعويض المبني على نظرية عمل الأمير شرطة تــوفر شــروط

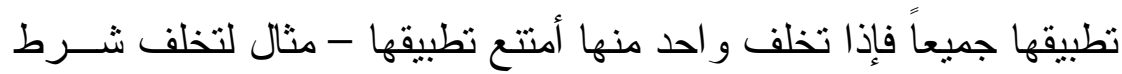
من شروط تطبيقها وقو ع ضرر قاضي بالمتعاقد لا يشاركه بغية سائر من

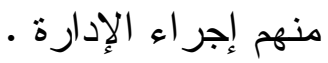
[ خامساً ] يترتب على توفر شروط تطبيق نظرية عمل الأمير إعادة التوازن المالي للعقد عن طريق تعويض المتعاقد عن الأضرار التي لحقت به

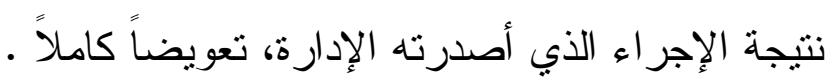

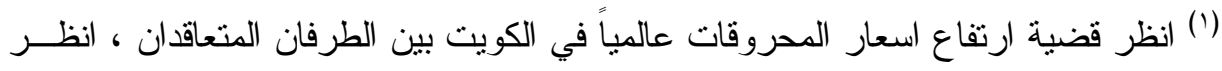

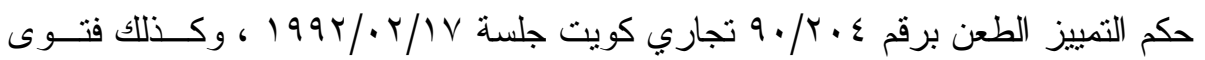

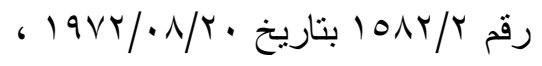

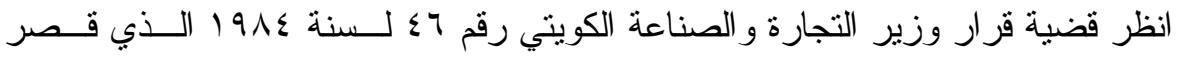

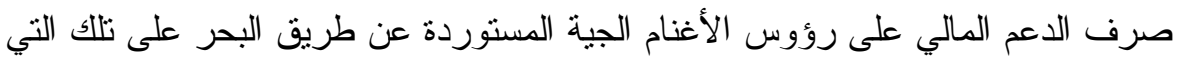

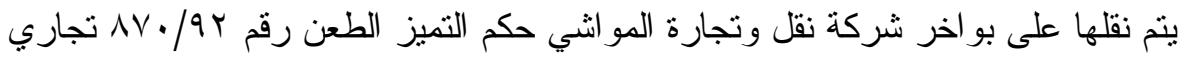

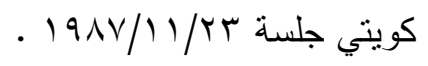


وفي ذلك استقر القضاء الإداري على أن يشمل التعويض ما لحق المتعاقد من خسارة بسبب عمل الأمير من قبيل ما تحمله من نفقــات إضــافية ورســوم

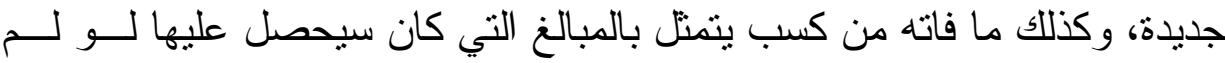
يختل التو ازن المالي للعقد، ويتم تقدير مبلغ التعويض باتفاق الطرفين، فإذا لم يتم هذا الاتفاق فإن القضاء يتولى هذا التقدير •

وقد بينت محكمة القضاء الإداري المصري الأسس التي يتم من خلالهــــا.

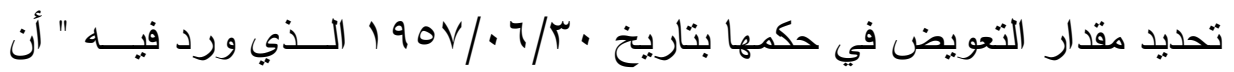

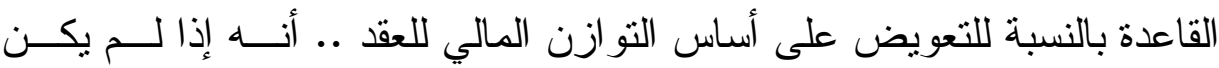

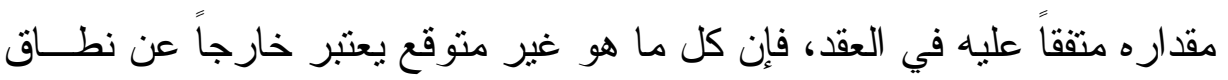
العقد فلا تطبق عليه شروطه ولتعبير " في هذه الخصوصية معنى خاص بها هو

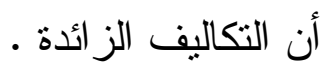

التي تلقي على عاتق المتعاقد تعتبر غير منوقعة، ما دام إنها لبست جزءً من الاتفاق، بمعنى أنه لا يقابلها في شروط العقد أي تقدير ، و المحكمة إنما تقدر هذا التعويض طبقاً للقواعد المقررة في القانون الإداري في هذا الثأن وهو يشمل عنصرين، الأول ما لحق المتعاقد من خسارة، ويتضمن هذا العنصر المصروفات الفعلية التي أنفقها المتعاقد، وهذه المصروفات تختلف باختلاف الأحو ال وطبيعة التعديل ونتائجه، ومثال ذلك ما إذا طلبت الإدارة سرعة إنجاز 
الأعمال، فإن ذلك قد يؤدي إلى زيادة التكاليف على المتعاقد بدفع أثمان مرتفعة أو زيادة في أجور الأيدي العاملة، كما أنه من الجائز إن ينرتب على تعديل أثثاء تتفيذه خسائر متتوعة وفي هذه الحالة يجب تقدير هذه الخسائر مادامت علاقة السبيية قائمة بينها وبين الإجراء الذي طلبت جهة الإدارة من المتعاقد معها اتخاذه، والثاني ما فات المتعاقد مع الإدارة من كسب اعنبارً بأن من حقه أن الإهر اهن يعوض عن ربحه الحلال من عمله ور أس ماله .. " [ سادساً ] يستطيع المتعاقد أن يطلب الجمع بين أكثر من أثر إذا تعددت الأسباب يسنطيع المتعاقد أن يطلب الجمع بين أكثر من أثز إذا تعددت الأسباب،

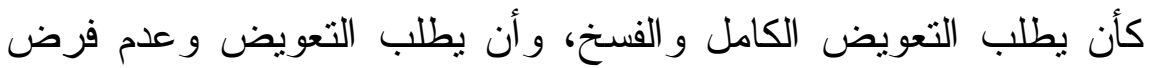
الغرامة التأخيريه، حيث أن المتعاقد له الحق لطلب عدم فرض الغرامات التأخيرية إذا كان التأخير يعزى إلى فعل الأمير (').

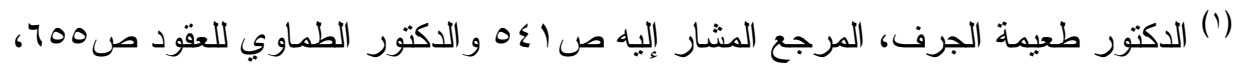

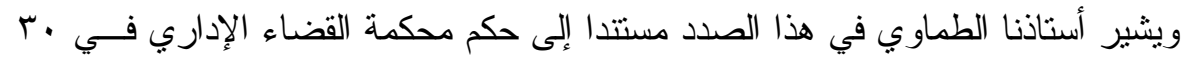
يونيو 190V المشار إليه من قبل إلى عدم مشرو عية النص الوارد في العقد الــــي يقــرر اعفاء الإدارة من كل مسئولية لتعارض ذللك مع المبادئ المقررة في القانون الإداري ومنها لئه

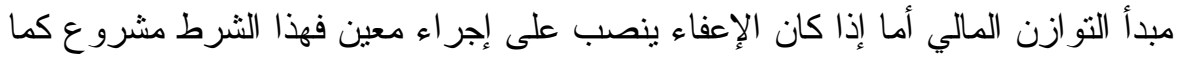

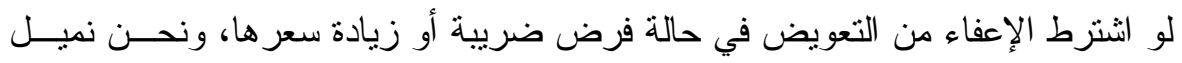

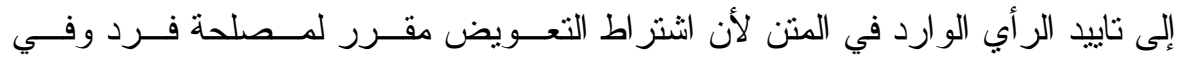

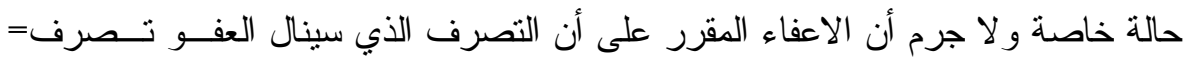


(theorie du L'imprevision) العنصر الثالث: نظرية الظروف الطائئة)

نظرية الظروف الطارئة كانت بدايتها من حكم مجلس الدولة الفرنسي الذي تم تأخيرها في حكمه بتاريخ ـ/T/T/T/ 19 بشأن قضية إثارة مدينة "بوردو" (') الظروف الطارئة فقد عرفها البعض بأنها: "عبارة عن ظروف

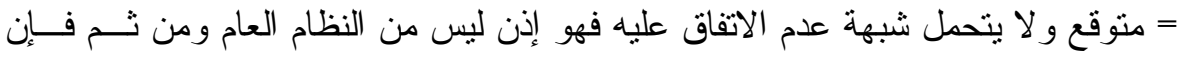

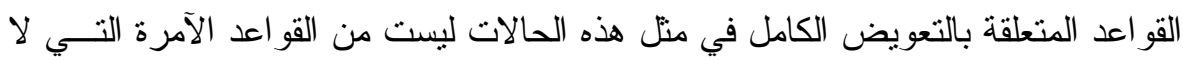

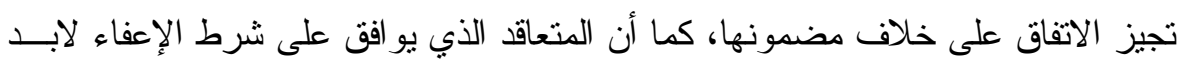

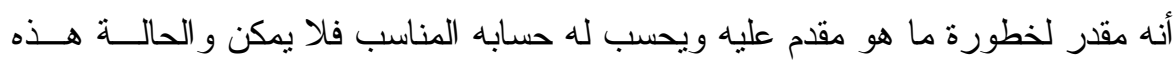

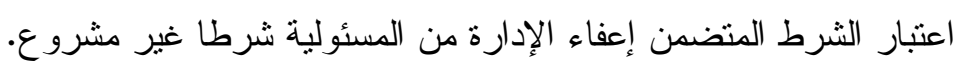

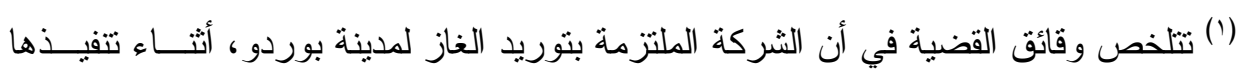

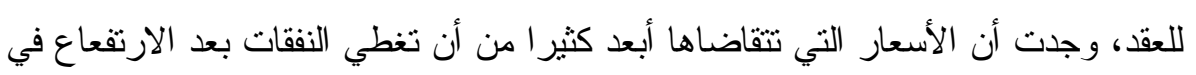

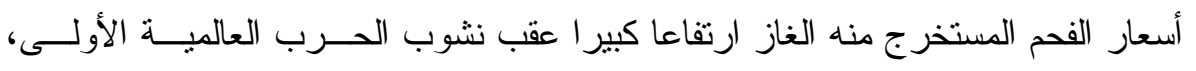

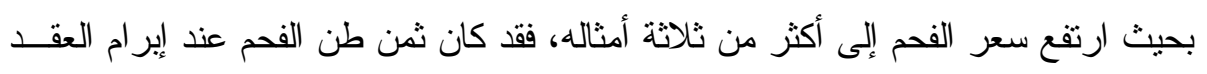

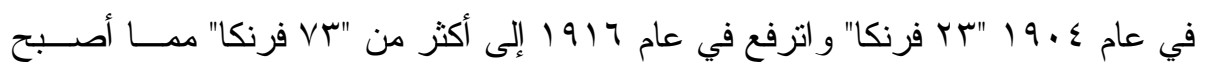

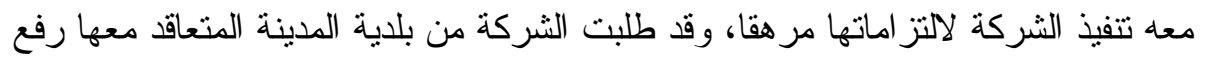

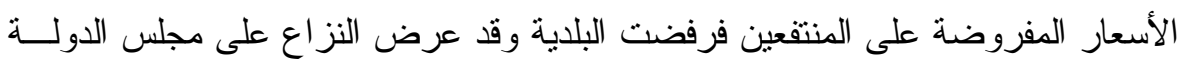

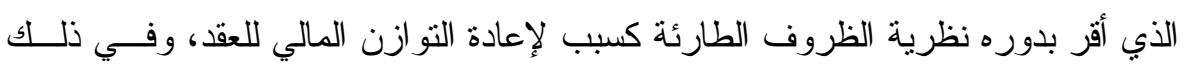

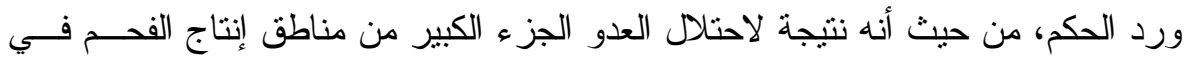

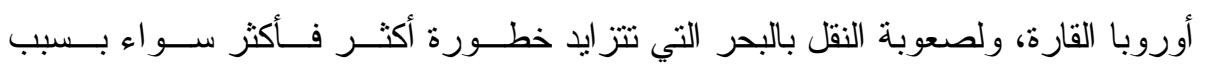

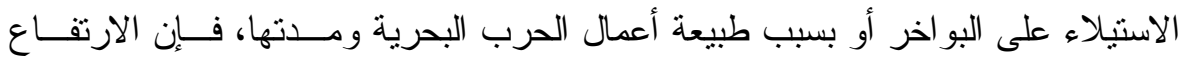

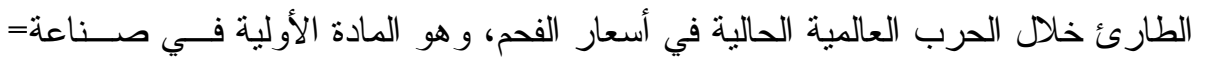


وأحداث استجدت أثناء تتفيذ القضية أمور خارجة عن إرادة المتعاقد مع الإدارة لم تكن منوقعة حدثت أثناء تتفيذ العقد الإداري أدت إلى قلب اقتصاديات العقد، إذا كان من شأن هذه الظروف أن تجعل تتفيذ العقد أكثر عبثا وأكثر كلفة وأكثر إرهاقاً مما قدره المتعاقان النقدير المعقول، و إذا كانت الخسارة النانشئة عن ذلك تجاوز الخسارة العادية التي يتحملها أي متعاقد إلى خسارة فادحة استثنائية وغير عادية، فإن من حق المتعاقد المضار أن يطلب من الطرف الآخر مشاركته في هذه الخسارة الني تحملها فيعوض تعويضا جزئياً، وبصفة مؤقتة و وإما بتعديل

= الغاز بلغ نسبة لا توصف فقط بأنها ذات طبيعة استثنائية بالمعنى المعتــاد لهــذا اللفـــا

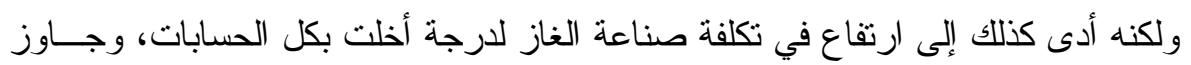

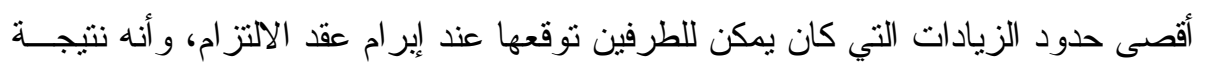

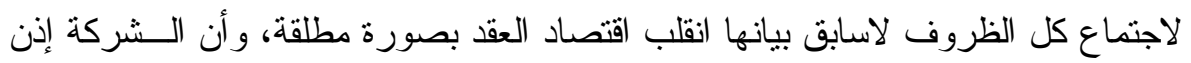

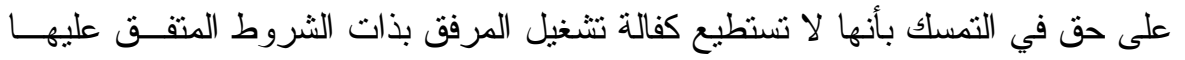
أصلا طالما استمر الموقف غير العادي المذكور أعلاه، وخلص المجلس من ذلك إلى قوله

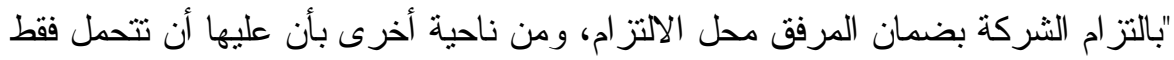

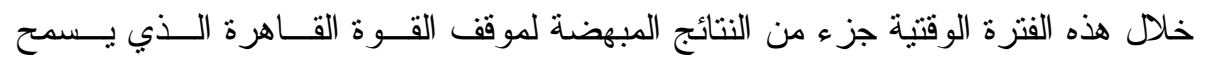

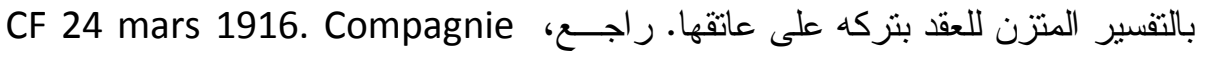
Du Gaz du bordeau

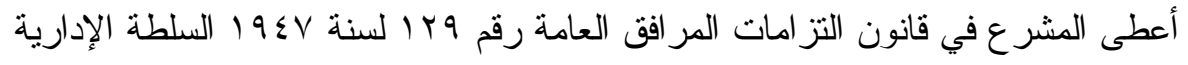

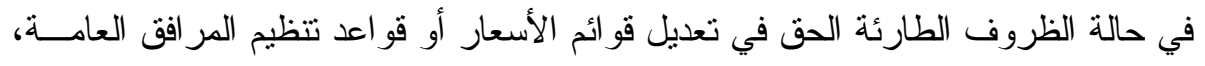

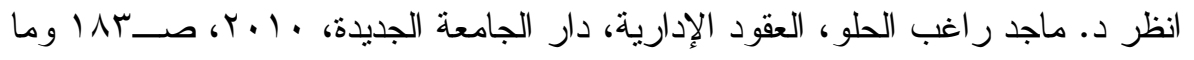


شروط العقد للتلطيف من أثز الظروف بما يسمح للمتعاقد بالاستمرار في تتفيذ العقد دون إرهاق، إنه يشترط لتطبيق نظرية الظروف الطارئة نوافر الشروط

( ) وجود أسباب طارئة عامة غير منوقعة أثناء التعاقد.

r) ألا يكون للمتعاقد مع جهة الإدارة دخل في وقوع هذه الظــروف بـسبب تقصير أو إهمال منه.

r) أن يكون في تتفيذ الالتز ام العقدي إلحاق خسارة جـسيمة غيــر معتـــادة

$$
\text { بالمتعاقد مع جهة الإدارة. }
$$

§) أن يترتب على تو افر الثروط السابقة حق المتعاقد مع جهة الإدارة فـي إعادة التوازن المالي للعقد ويأخذ التعويض في هذه الحالة عدة صور

يحق للقاضي أن يوزع الخسارة التي أصابت المتعاقد نتيجة للظــروف الاقتصادية على الطرفين المتعاقدين.

كما يجوز للقاضي أن يههل المتعاقد مع جهة الإدارة في تتفيذ التز اماته العقدية إذا وجد أن الظرف الطارئ قابل للزو ال في وقت قــير ، ولا يصيب جهة الإدارة ضرر من هذا الإهمال. 
و أخير ا يجوز للقاضي فسخ العقد في الجزء الذي لم يتم تتفيذه، وذللك إذا

ما كان في فسخ العقد مصلحة للطرفين، وذللك مع تعويض جهة الإدارة عن جانب معقول من الخسارة التي لحقت بهما نتيجة فسخ العقد، بحيث يتحقق في النهاية النوازن المالي بين المتعاقدين.

\section{الآثار المترتبة على تطيق نظرية الظروف الطارئة:}

تطبيق نظرية الظروف الطارئة متى نو افرت شروطها لا تعفي المتعاقـــــ من تتفيذ التز اماته فالمتعاقد يقى ملزما بالاستمر ار في تتفيذ العقد، وهذا ما يميز نظرية الظروف الطارئة عن القوة القاهرة التي تجعل تتفيذ الالتـز ام مسـتصيلا. كما تختلف نظرية الظروف الطارئة عن نظرية عمل الأمير في أنه يترتب على

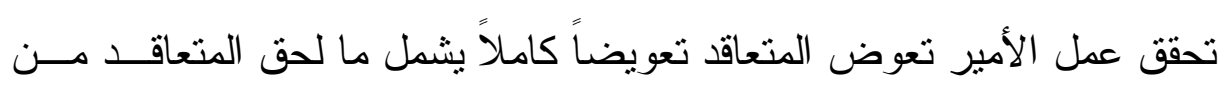
خسارة وما فاته من كسب أما في نظرية الظروف الطارئة فــإن التعــويض لا لا يغطي إلا الخسائر التي نجمت عن الظرف الطارئو التــي تجــاوزت الحـدود المعقولة.

وقد بينت المحكمة الإدارية العليا هذا المبدأ بقولها "أن التعـويض الــذي

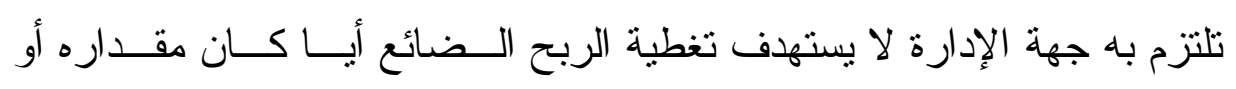
الخسارة العادية المألوفة في التعامل و إنما أساسه تحمل الجهة الإدارة المتعاقــــة لجز ء من خسارة محققة وفادحة، والإدارة في سبيل تعويض المتعاقد قد تتفق مع 
المتعاقد على تعديل العقد وتتفيذه بطريقة تخفف من إرهاقه وتتحمل عبء هــذا الإزرهاق بالقدر الذي يمكن المتعاقد من الاستمر ار بتتفيذ العقد، و إذا لم يــتم هـــا الاتفاق فإن للقضاء أن يحكم بتعويض المتعاقد استتاداً إلى التفسير المعقول للعقد. هذا ويتميز حق التعاقد في اقتضـاء التعـــيض وفــق نظريــة الظــروف

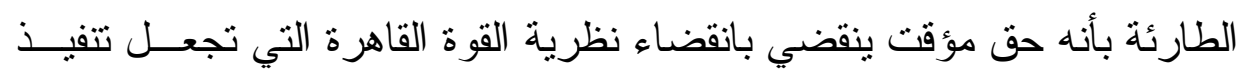

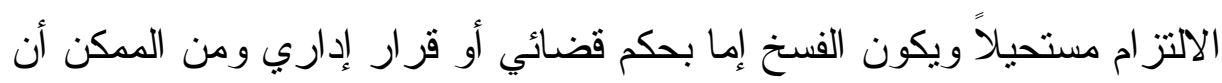

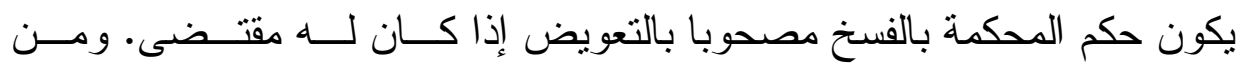

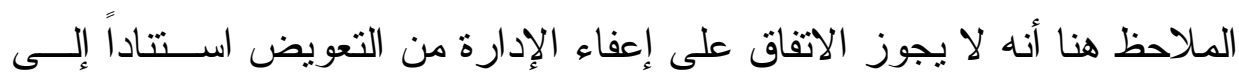

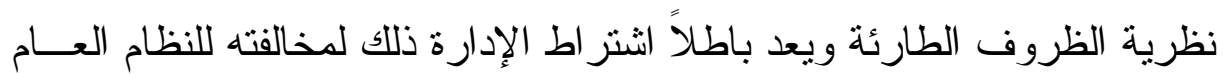

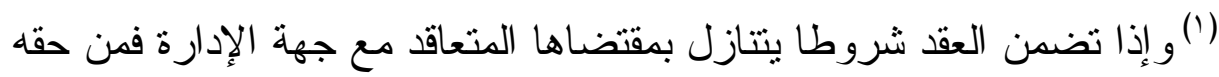
المطالبة بالتعويض عن الظروف الطارئة متعلقة بالنظام العـام لاســيما وســيلة

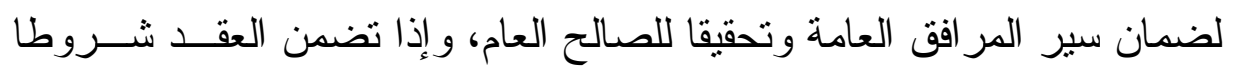

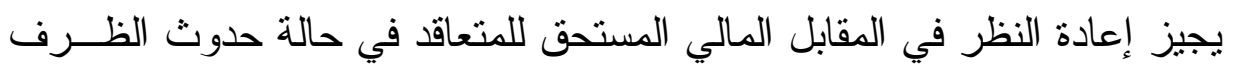

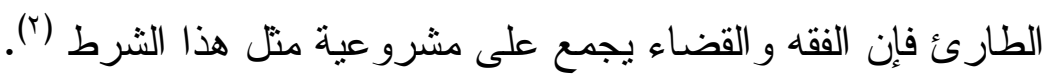

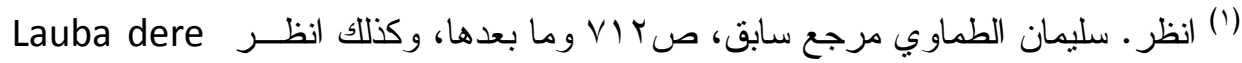
(A.Df) modern (F) Delvolve (p) op.cit. P558.

CE-11-2-1983, ste entre prise caroni, Rec. P. 61

CE-15-7-1949 Ville d'Elbeaf . Rec. P. 61

CE. 2-2-1951, ste des grands Travaux de marsille, Rec. P. 68 
جدول يبين شروط و آثار كل نظرية من النظريات الأربع على الثكل التالي:

\begin{tabular}{|c|c|c|}
\hline الآثـــار & الشروط & وجة المقارنة \\
\hline 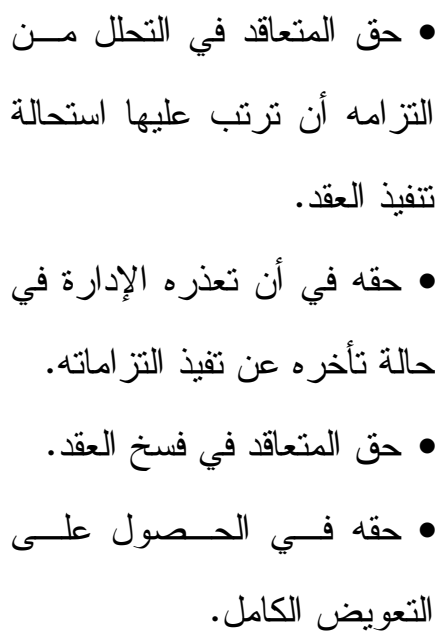 & 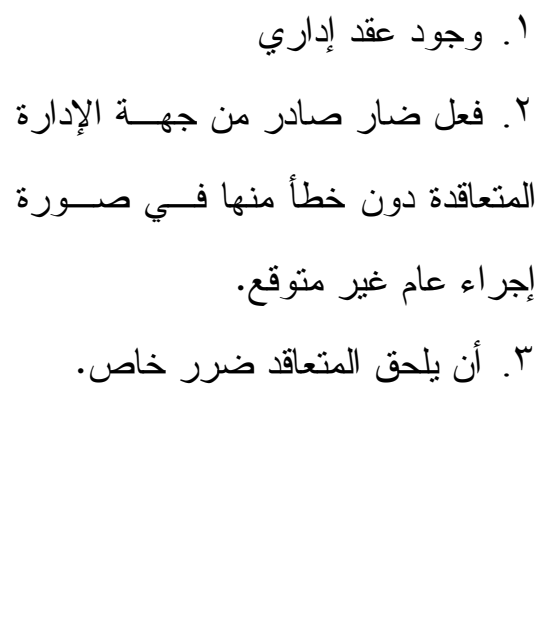 & عمل الأمير \\
\hline 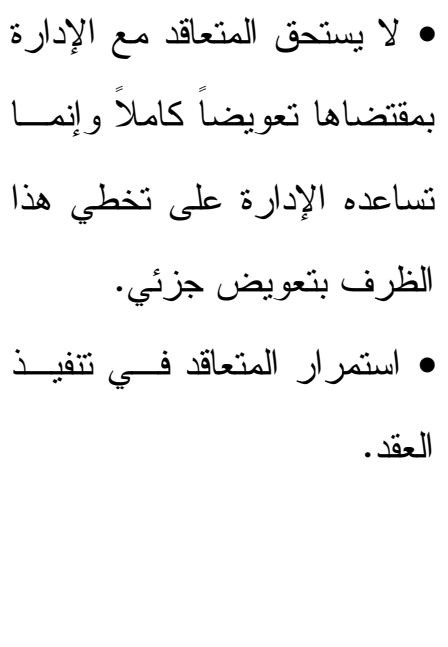 & 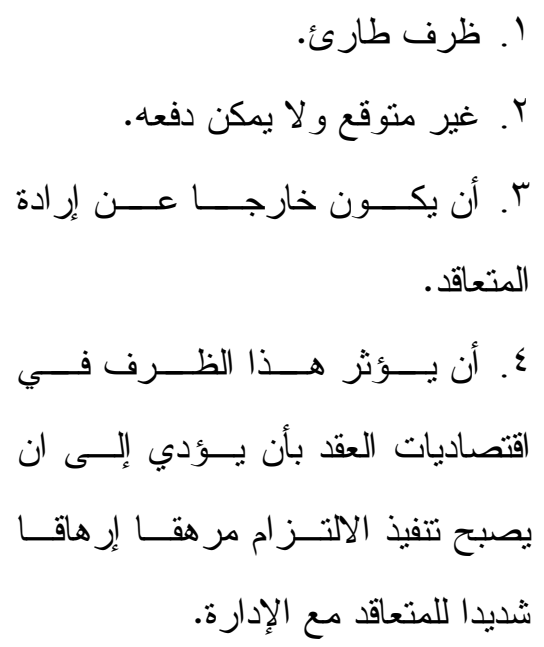 & الظـــــروف \\
\hline
\end{tabular}

مجلتة البحوث القانونيت والإقتصاديت ؟ ؟ 
أ.د / فؤاد نصر الله عوض

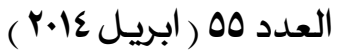

\begin{tabular}{|c|c|c|}
\hline الآثــــار & الشروط & وجة المقارنة \\
\hline 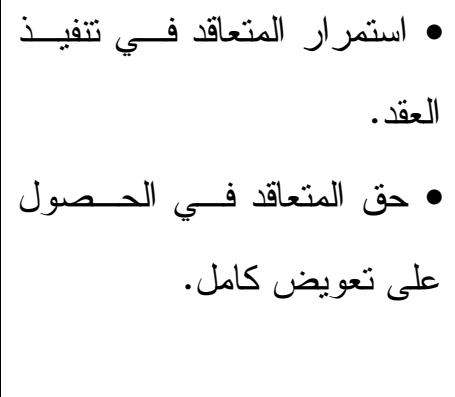 & 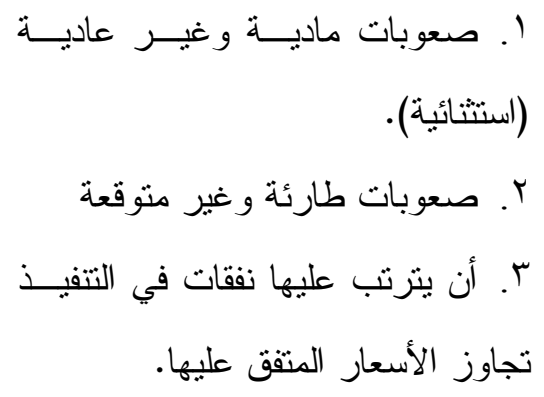 & الصعوبات \\
\hline 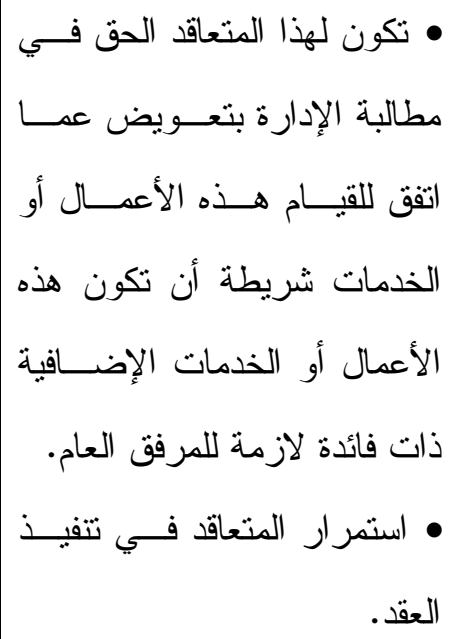 & 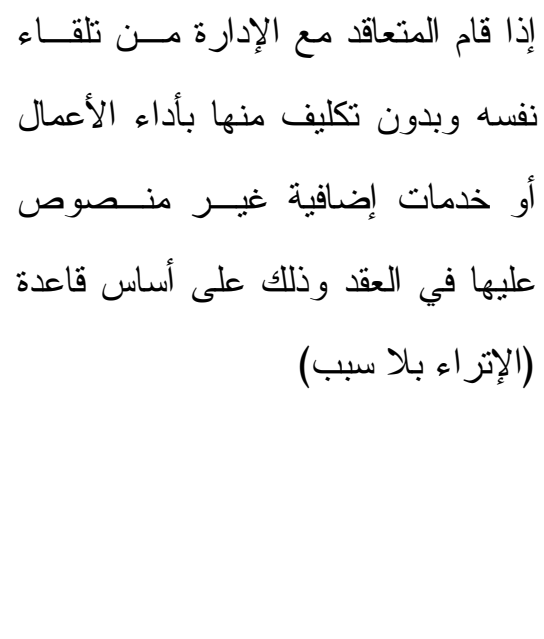 & بلاسبب الإثر اء \\
\hline
\end{tabular}

مجلت البحوث القانونيت والإقتصاديت ه ؛ 


\section{الاملب الثانسي}

\section{حق المتعاقد في فسخ العقد الإداري المعدل هن قبل سلطة الإدارة}

Le Droit du co-contractant a'la resiliation du contrat Administratif modifie

قد بينا فيما سبق في بحثنا هذا على ما تتمتع الإدارة صاحبة التعاقد مسن

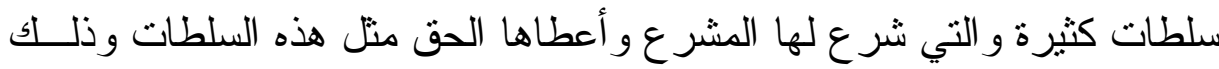
لمو اجهة المتعاقد الآخر وفقاً لإر ادتها المنفردة و التي أيدت فيها و الاعتر اف معظم الفقهاء وما ذهب إلى القضاء في هذا الثـأن، في مقابل ذلـــك أعطــى القــانون و القضاء من حقوق المتعاقد الآخر من حقوق لعل أبرز ها حقه فــي التعـويض

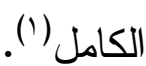

وكما رأينا أن سلطة الإدارة صاحبة التعاقد في تعديل العقد الإداري ليست

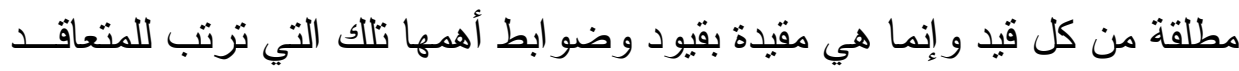
حقا في طلب فسخ العقد الإداري هو حق للسلطة الإدارية في اتخاذها وذللك هــ

(1) يستجوب على الإدارة أن تقوم بإخطار المتعاقد معها قبل الإنهاء إذا نص العقد على مهلـــة

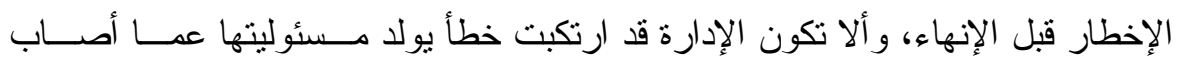

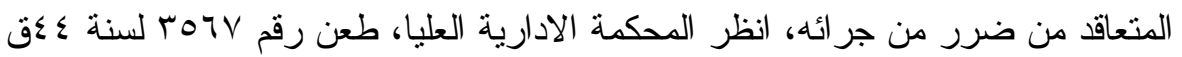

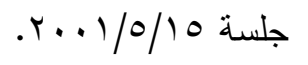

مجلتً البحوث القانونيتوالإقتصاديت צ ؛ 
جز اء توقف هذه الإدارة المتعاقدة على المتعاقد معها الذي لم يعد قــادراً علــى الوفاء و اخلاله بالتز امه التعاقدي على نحو ما ينبخي، حيث تتمـي الإدارة لهــذا الجز اء التعاقد معه بصورة مبنرة تفرضها موجبات تخفيض المصلحة العامة في دو ام سير المر افق العام بانتظام.

وتملك الإدارة حق فسخ العقد الإداري، سو اء انطوي هذا العقد على نص يحولها هذا الحق أم خلال من النص على ذلك ودون حاجة للجوء للقضاء، حيث أن هذا الحق من مظاهر السلطة العامة (') فقر ار الفسخ هو إجــر اء تعاقـدي لا لا يخضع للأحكام العامة الخاصة بإلغاء تطور ات الإدارية قضائيا و إنما يكون محلاً للطعن على أساس استعداء ولاية القضاء الكامل (r) فالقرار الصـادر عـن جهــة الإدارة لفسخ العقد هو قر ار متعلق بتتفيذ العقد، ولا يعتبر بذلك قرار ا إداريــاً (r) أما أهم حقوق المتعاقد في استخدامها لحق فستخ العقد المعدل مــن قبــل ســلطة الإدارة بإر ادتها المنفردة وفقاً للعناصر التالية:

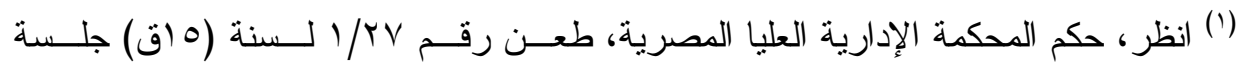

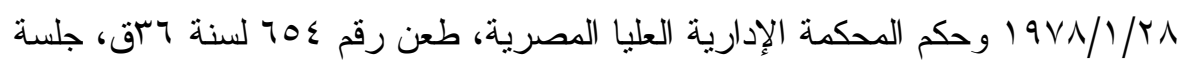

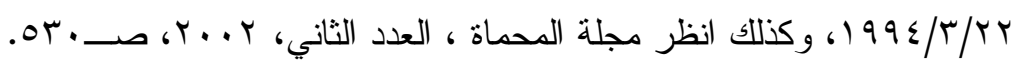

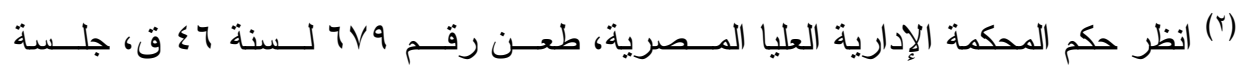

$$
. r \cdot 1 / \mathrm{r} / \Lambda
$$

(r) انظر د. عبد العزيز عبدالمنعم خليفة، الأسس العامة للعقود الإدارية، المرجع السابق، .9،

$$
\text { وما بعده. }
$$

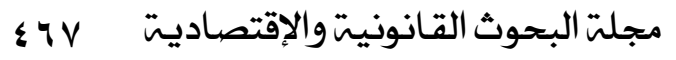


العنصر الأول: الشروط الأساسبة التي بموحيها بحق المتعاقد طب الفسخ .

\section{Les conditions dans les quelles laresiciation peut interwenir}

هناك أسباب ومبررات كثيرة التي يحق المتعاقد الآخر مع الإدارة التي تفسخ أمامه العقد الإداري المتفق عليه بين الطرفين بالإيجاب و القبول أهمها: أولا: يقع الفسخ من قبل المتعاقد سواءً نتيجة لخطأ الإدارة المتعاقــدة أو بــدون خطأ منها على الرغم بأن هذا الأمر يتم بواسطة القاضــي أو بالتر اضــي

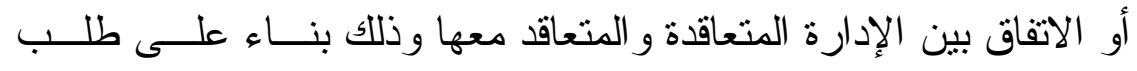
المتعاقد الآخر (المناقص أو التاجر) وذللك لاختلاف في طبيعة وشـروط بنود الفسخ ووفقاً لظروف و أهمية هذا العقد في وقت إبر امسـه فــي كلتــا الحالتين ('). (1)

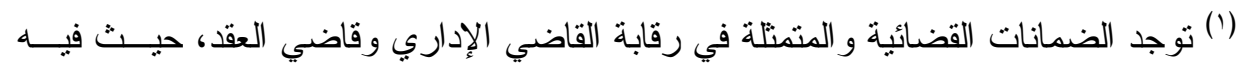

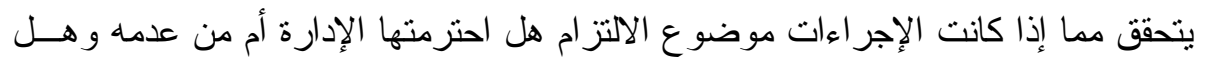

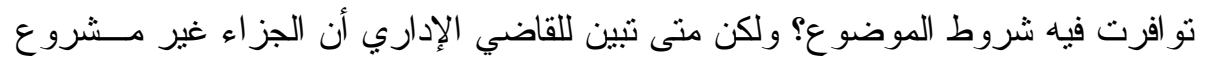

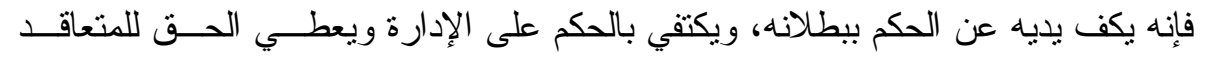

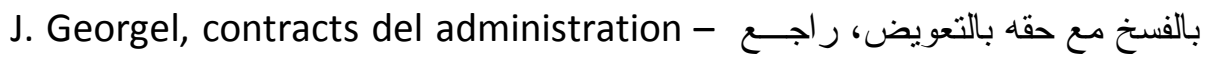
J.C.A. 1986 Face 510, No 41, P.10 - Devillier S.M. Droit public general, .litec, 2004, P. 677.

مجلتً البحوث القانونيت والإقتصاديتة 1 ؟ ؛ 
كما قضت المحكمة الإدارية العليا المصرية في الطعن رقـم 0 ـ لــسنة

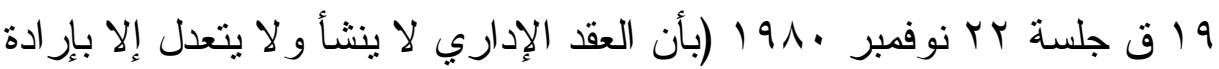
صحيحة من جهة الإدارة صـادرة ممن يملك التعبير عن هذه الإز ادة وبناء علـى ذللك يجوز لجهة الإدارة أن تعدل من شروط العقد الإداري و لا سبيل إلـى قيــام هذا التعديل و الاعتداد به قانوناً مالم تلتزم عند إجر ائه)(')، فسلطة التعــديل هـذهـ ليست سلطة مطلقة من كل قيد فهناك من القيود ما يتزتب على مخالفــة الإدارة لها بطلان العقد (r)، و إذا كانت الإدارة تملك هذه السلطة الاســتنائية مــن دون الحاجة للنص عليها في العقد ومن غير حاجة إلى موافقة المتعاقد مــع الإدارة، فإن استعمال الإدارة لهذا الحق يقابله في الوقت نفسه ضــمانات المتعاقـــــــي مو اجهة الإدارة، ومن بين تللك الضمانات حق المتعاقد فــي فـسخ العقــد مــع التعويض كجز اء على مخالفة الإدارة في استعمال هذه السلطة وهي من الحالات التي يحق للمتعاقد فيها طلب العقد الإداري.

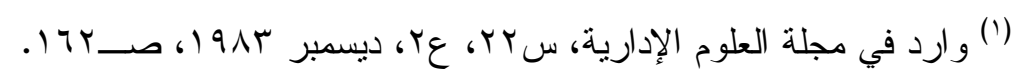

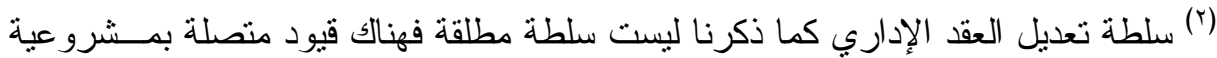
الإجر اءات التي تتخذها الإدارة لتعديل عقودها، ومن هذه القيود (أن يقتصر التعديل علـى لـى لإيل

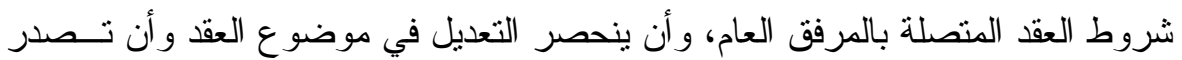

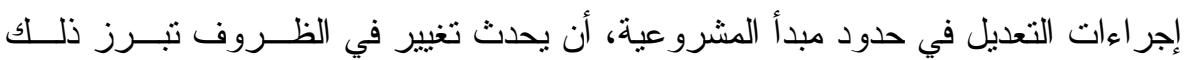

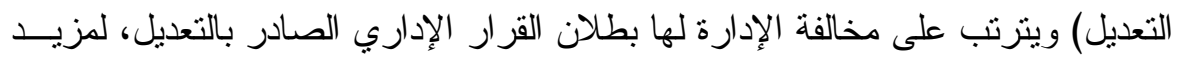

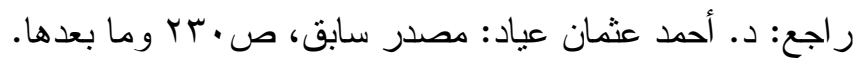


ثنانيا: إذا ثبت هناك بأن للإدارة المتعاقد قد ارتكبت خطأ جسيم من قبلها سواء متعدداً أو غير متعدداً في هذه الحالة يقع الفسخ كعقوبة للإدارة المتعاقدة نتيجة لاقتز افها خطأ مما أدى إلى ضرر كبير لهذا المتعاقد. ثالثا: أما في حالة عدوم وجود خطأ منها (للإدارة المتعاقدة) ولكنه فيه كنو عن التعسف في استعمال السلطة مما أدى إلى خسارة وضرر لهذا المقاول للطرف الاخر للتعاقد ففي هذه الحالة فعملية الفسخ تعتبر حقا معترف به للمتعاقد يستطيع بموجبه أن يتخلص من عقد أصبح تتفيذ بنوده وشروطه

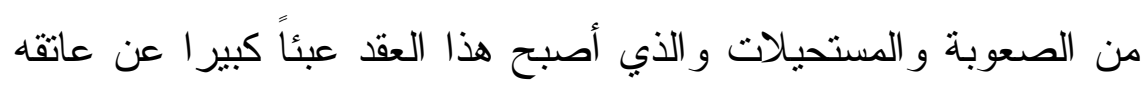
من جراء ما أدخلت عليه الإدارة المتعاقدة من تعديلات بإر ادتها المنفردة وذلك بما تتمتع هذه السلطة من سلطة تقريرية و السعة يخولها بتعديل بنود وشروط العقد تشاء ذلك وفقاً للمصلحة العامة (').

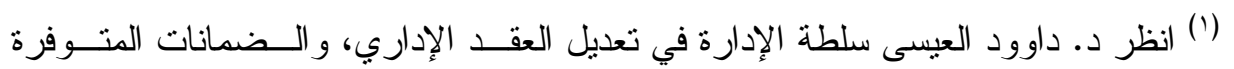

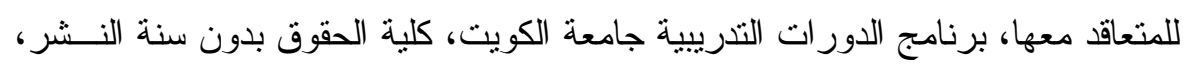

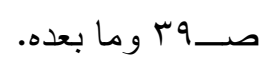

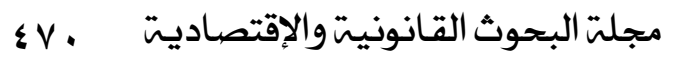




\section{رربعا: إذا تجاوزت الإدارة الحدود المرسومة للتعديل:}

Si la modification exceed manifestement les previsions des parties:

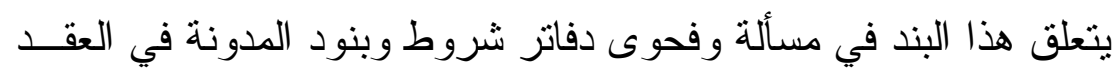
الإداري و الذي يذكر فيه الحد الأقصى للتعديلات و لا يجوز تجاوزهو إلا أصــبح

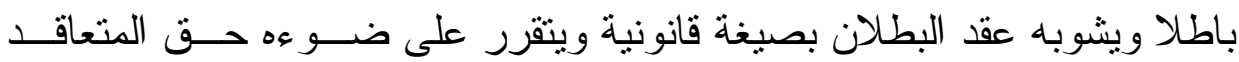
الآخر في عملية فسخ و إسقاط العقد إذا تجاوزت السلطة الإدارية في تعديل العقد الإداري بإر ادتها المنفردة إلى جانب و احد أحادي دون أخذ مو افقة الطرف الثاني

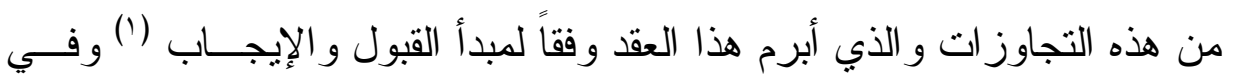
هذه الحالة إذا لا يجوز أن تتجاوز في تعديلاتها للعقد الحد المنصوص عليه فـي

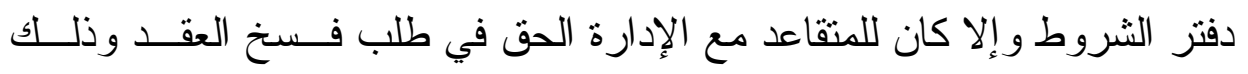
خلافاً عليه عند النعاقد وقد إبر ام العقد.

Benoit .P. Droit Administratif francis Daloz, Paris, 1968, P. انظـــ (1) و انظر كنلك، Roche. R. précis de droit public Bunod Paris, 1973, P. 687 
خامسيا: إذا ترتب على التعديل من قبل سلطة الإدارة فــرض أعبـــاء جديدة تؤدي إلى ار هاق المتعاقد وتجاوز إمكانياته الماديـــة أو الفنية:

Si lamodification impose au co-contrau ant des charges qui excedent ses forces finacieres on ses possibicites techniques:

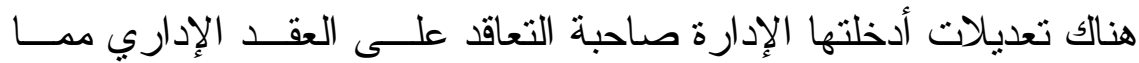
يؤدي إلى زيادة أعباء المتعاقد معها باعتبار تللك الإدارة بما تملك سلطة تقديريــة و اسعة في تعديل العقد الإداري وفقا لإدارتها المنفردة، وذلك لتحميل هذا المتعاقد الآخر بأعباء جديدة غير موجودة بشروط كر اسة التعاقد المتقق عليه مـن قبــلـ إدارة التعاقد مع المناقص الطرف الثاني للتعاقد و التي تفوق طاقته أو إمكانياتـــــ المادية و المالية و الفنية و الإدارية مما يؤدي نتيجة ذلك بإعطاء حق هذا الأخيــر

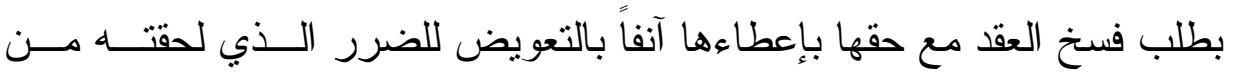

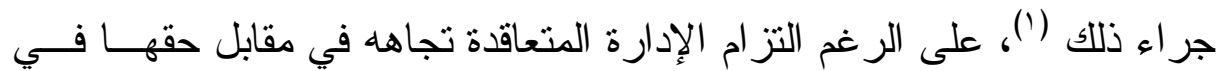
التعديل وفقاً لإر ادتها المنفردة، بحيث لا يمكن هذا المناقص المتعاقد الآخر فـي

(1) انظر، د. حمدي علي عمر ، المسؤولية النعاقدية للإدارة، دار النهضة العربيـة، القـاهرة،

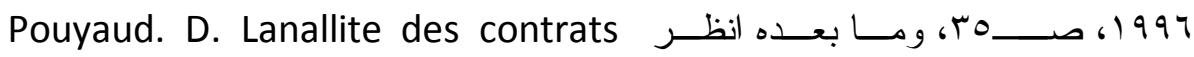
.Administratifs L.G.D.J. Paris 1991, P 539. 
إجباره و إلز امه على مو اصلة تتفيذ العقد في هذه الظروف ســيؤدي حتمــاً مــع مرور الزمن التي حدد على أساسه إلى عجزهوتعثره في الاستمر ار فـي ذلــــ ونوقفه نهائياً عن متابعة هذا التتفيذ بالنظر إلى ما يتوفر لايـــهـ مــن إمكانيــات وطاقات مادية وفنية وبالتالي توقف المشروع المر اد تتفيذه مما يكنــف بالتــالي أعباء وتكاليف مالية على خز انة الدولة.

فالتعديلات التي تباشرها السلطة الإدارية لابد ان تكون ضــمن الحــدود المنطقية دن حيث نو عها و اهميتها، بشكل لاتصل التعديلات الـى حــــ ارهــاق المتعاقد او تغيير موضوع العقد الاصلي او تتشئ محلاً جديداً بشكل يجد المتعاقد نفسه امام عقد جديد، يختلف عما تم الاتفاق عليه مقدماً، فللمتعاقد حينئذ الحق في طلب فسخ العقد مع التعويض عما يصيبه من اضرار ('). وقــد ابـرزت ذلــك محكمة القضاء الإداري المصري في حكم لها قائلة: (سلطة التعديل هـذذه وان كانت تتناول وتتمل جميع العقود الإدارية بما فيها عقود التوريد الا انها ليـست مطلقة بل تزد عليها قيود...من هذه القيود ما يتصل بمقدار الاعباء الجديدة التـي تلقى على عانق المتعاقد مع الإدارة نتيجة لممارستها هذه الــسلطة اذ يجــب ان

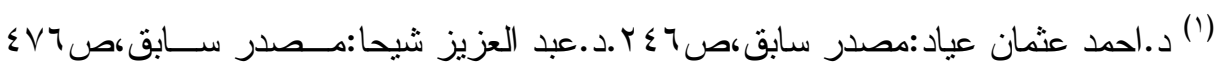

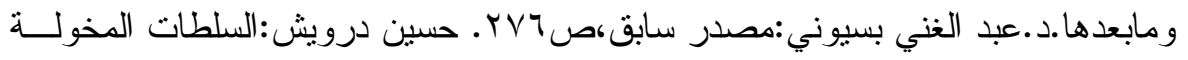

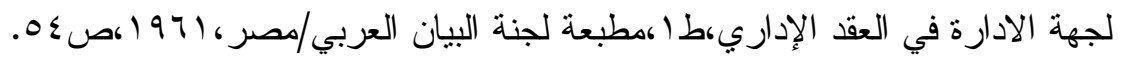


تكون تللك الاعباء في الحدود الطبيعية و المعقولة من حيث نوعها و اهميتهــا، لا ان يكون من شأنها فسخ العقد الاصلي او تبديل موضوعه او انشاء محل جديــــ له غير ما تم الاتفاق عليه، او ان تؤدي هذه الاعباء الى ارهاق المتعاقد فتجاوز امكانياته الفنية او المالية او الاقتصادية و الاجاز لله ان يمتتع عن تتفيذها بل لــــ ان بطلب فسخ العقد تأسيساً على ان التعويض الذي تلتزم به جهـــة الإدارة فــي مقابل حقها في التعديل لا يكفي لاصلاح الضرر الذي ينشأ عن هذا التعديل، فله ان يتفادى النتائج الخطيرة المرهقة التي كان يتحملها، وتقدير ذلك كله يدخل فـي

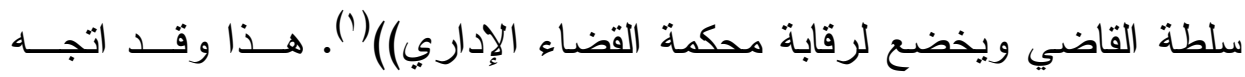
القضاء الإداري المصري في قرار ات لاحقة الى منح المتعاقد حق التعويض في

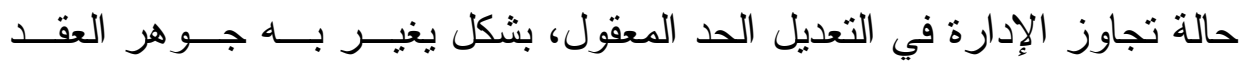
الإداري او يتغير محله ويؤدي الى قلب التو ازن الاقتصادي للعقد.

(1) لقد اثنارت الى فكرة تغيير موضوع العقد تغيراً جو هرياً المحكمة الإدارية العليا المصرية

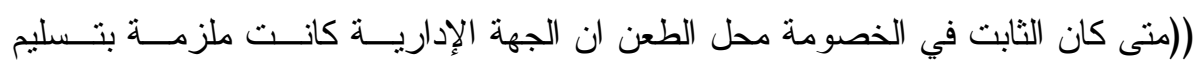

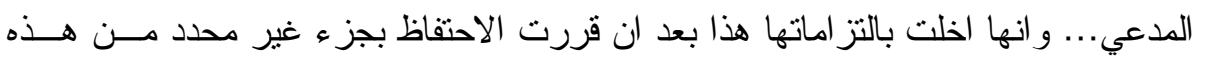

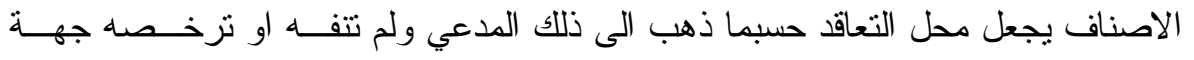

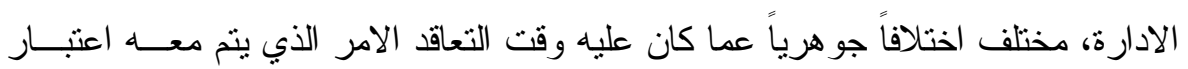

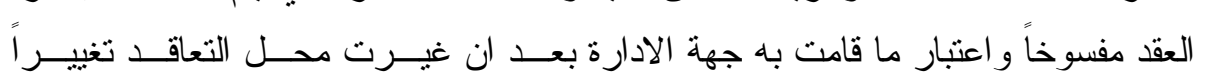

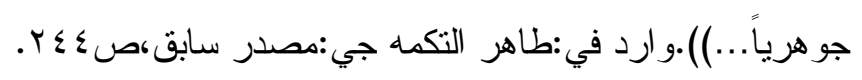


وقد اكدت ذلك محكمة القضاء الإداري الــصرية ((...كمـــا يجـب الا تقرض الإدارة على المتعاقد تعديلات تجعله امام عقد جديد ما كـــان ليقبلــهـ لــــ

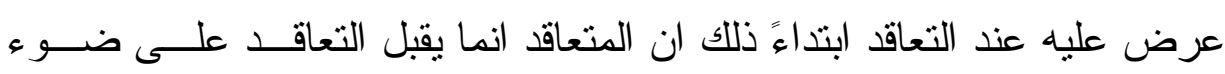
امكانياته المالية و الفنية ولذلك كان و اجباً على جهة الإدارة عند ممارستها سلطة

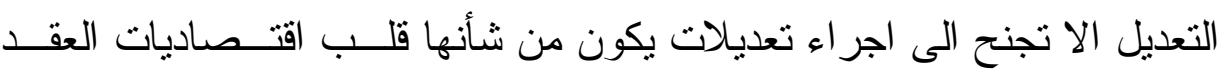
وتحميل المتعاقد اعباء مالية تتوء بها طاقته فاذا ما لجأت الإدارة الى شيء مــن ذلك كان للمتعاقد الحق في اقتضاء التعويض بها بالقدر الذي تختل به الموازنـــة في شروط العقد)('). هذا ويرى مجلس الدولة الفرنسي الاكتفاء بفسخ العقد فيما

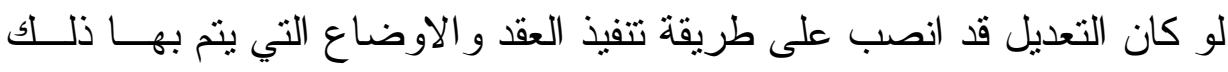
النتفيذ(؟)

$$
\text { (1) طاهر النكمة جي: مصدر سابق أيضاً،ص \& ؟ ب. }
$$
C.E 28 Mars 1866,Syndicat de Varades, R.P309. (r)

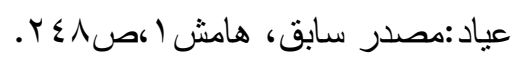

مجلة البحوث القانونيت والإقتصاديت 
سادسا: إذا أدى التعديل إلمى قلب اقتصاديات العقد رأسا على عقب:

Si la modification est telie que l'economice du contrat se trouve boulersee:

إذا أدى تعديل العقود الإدارية من قبل سلطة الإدارة المتعاقــدة بإر ادتهـــا

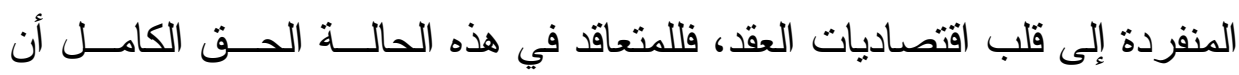
يطلب فسخ العقد المبرم مع الإدارة مع الأخذ بالتعويض إذا ما تحقق ما يوجبه. فإذا تركز التعديل على كمية العمل المطلوب إنجازه بالزيادة أو النقصان،

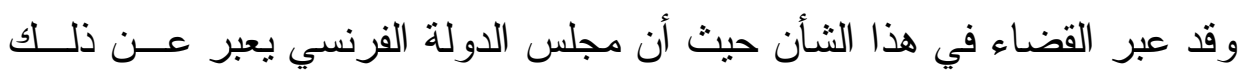

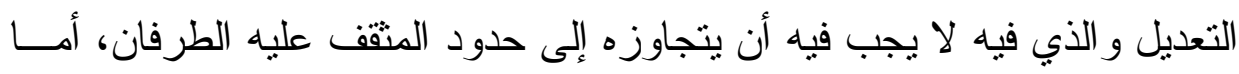

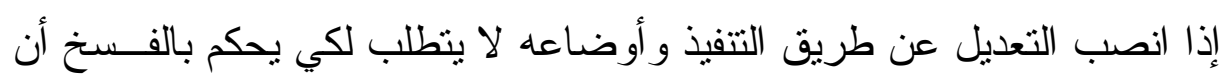
يؤدي فيه التعديل إلى قلب اقتصاديات العقد بدرجة ملحوظة. فقد فسر حكم المحكمة مجلس الدولة الفرنسي موقفه من هذه المسألة فـي حالة وقعت على المورد المتعاقد مع الإدارة حيث طلبـت ســلطة الإدارة مــن

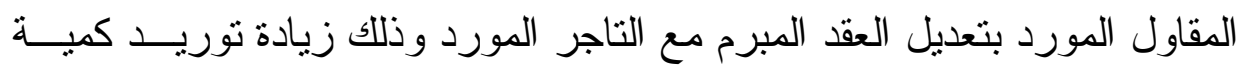

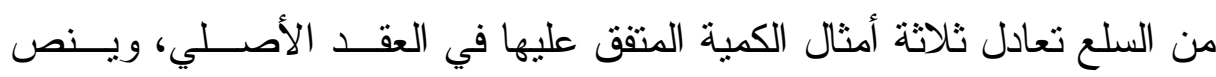
مجلس الدولة الفرنسي رفضه لطلب سلطة الإدارة في تعديل العقد بزيادة كميــة السلعة المستوردة بخلاف ما اتفق عليه، وكذلك قد قوبل طلب المتعاقد الآخر حق بقدي 
فسخ العقد المبرم مع الإدارة و التي من جانبها قد خفضت الكمية المطلوبــة مــن

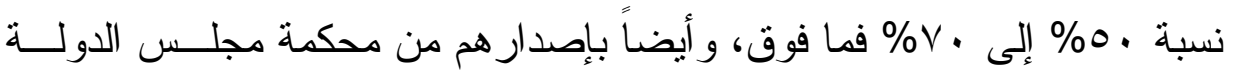
الفرنسي بقبول طلب مقاول آخر في فسخ العقد الإداري المبرم مع سلطة الإدارة

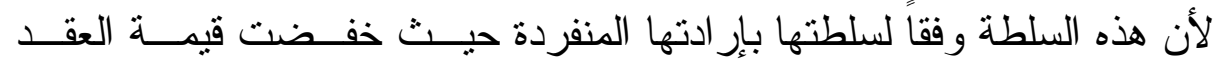

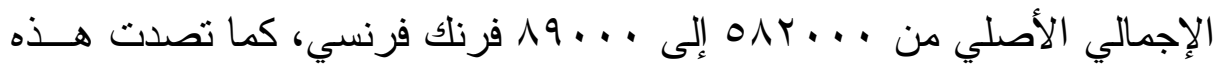
المحكمة لموضوع "الأعمال الجديدة لتعديل العقد، و التي بحق ليست مـــا تمـــت بصلة بنود وشروط العقد أولدت الاعتر اف بالأعمال الأصلية المتفق عليه مسبقا،

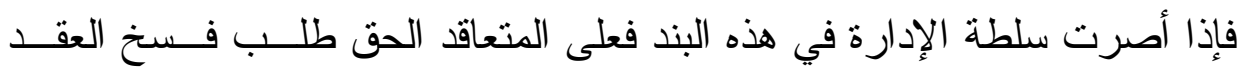

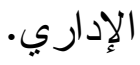
الآثار المترتبة على فستخ العقد من قبل المتعاقد:

Les affects delà resiciationda contrat:

الر ابطة العقدية للعقد المبرم ما بين الطرفين تبقى قائمسـة ومسـستمرة و لا تشوبه أي شائبة قانونية تبطل أثناره ومركزة القانوني وذلك باعتبار أن المتعاقــــ ( المناقص ) يستمر ملتزماً بتتفيذ بنود وشروط العقد إلى حين إصدار حكم مــن المحكمة الإدارية بفسخ العقد المبرم ما بين الطرفين وإلا بفرض هذا المتعاقد إلى

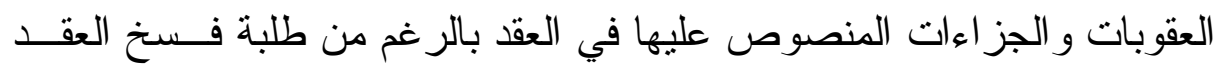


وينتج أثزه (') من يوم تقديمه لرغبة في فسخ العقد الإداري ، وكما أنه في حالة

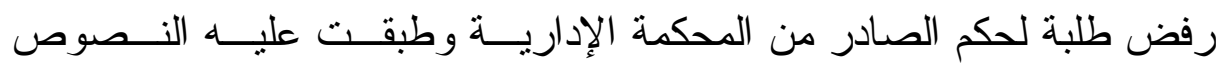

و الثروط الجز اءات في حالة تخليه عن تتفيذ شروط العقد وعدم التز امه بها (؟) أما إذا صدر حكم من المحكمة الإدارية بفسخ العقد فإن فهذه الحالة بــأن المتعاقد قد يتحلل من التز اماته ما مع استحقاقه بالتعويض •

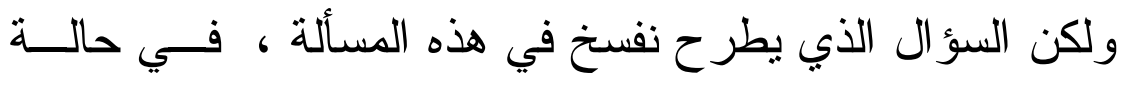
طلب المتعاقد بفسخ العقد الإداري المبرم مع الإدارة فهل فهذه الحالـــة

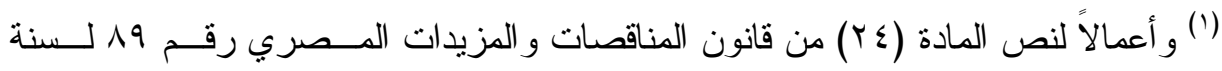

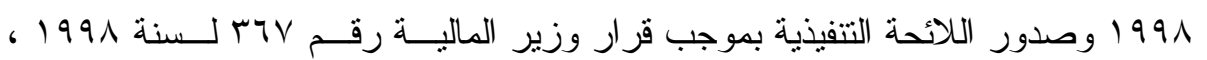

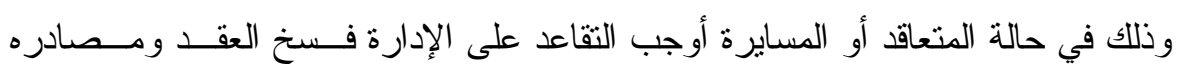
التأمين. كما أنه لا يجوز المتعاقد أن يمتتع عن الوفاء بالتز اماته للمرفق العام بسبب إخــله الإدارة

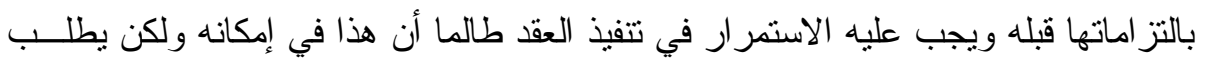

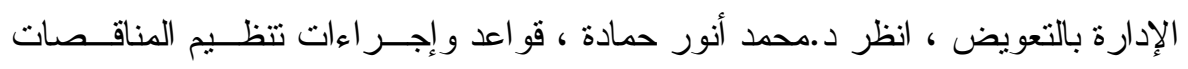

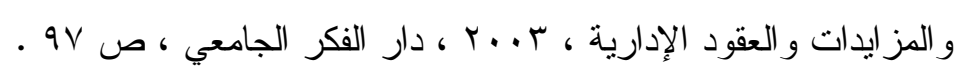

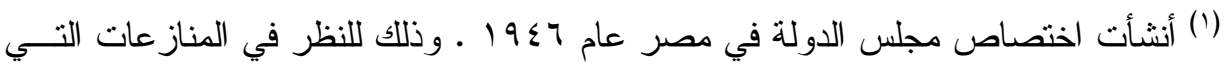

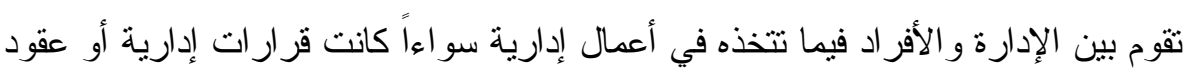

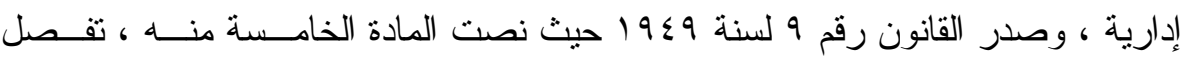

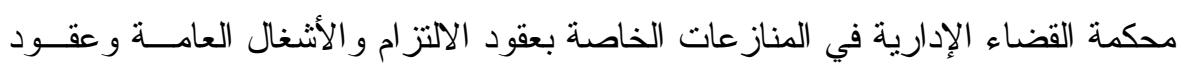

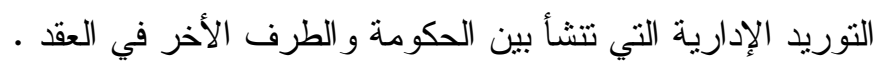


تعوضه الإدارة تعويضاً كاملاً أو تعويضاً جزئياً ؟ فالإجابة على هــذا

التشاؤل ، كما نعرف بأن سلطة الإدارة بإمكانهـــا أن تفـسخ العقــــ الإداري بإر ادتها المنفردة بشرط أن تعوض المتعاقد معهــا تعويــضـاً مادي كاملاً وذلك جر اء خسارته من هذا الفسخ وعطاءه حقوقه كاملة تو ازي ما فاته من ربح و الذي علــى أسـاســـة أقــــام هــــا المقـــاول (المناقص) أو المتعاقد على إبر امه للعقد مــع الإدارة المعنيــة إذا أن هناك حالتين تم الفسخ بفعل عمل الإدارة وهي: الحالة الأولى : فيها أن ينت تعويض المتعاقد الأخر مقابل الميزات التي يمنحهـــا فيها العقد وذللك بأن سلطة الإدارة بفسخ العقد بإر ادتها المنفردة وفقاً لممارســتها سلطنها بأن غير مقيد للمرفق العام وأنه لابد في هذه الحالة وليس للمتعاقد إلا أن

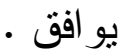
عن ذلك في فسخ العقد الإداري باعتبار ليس له أي دولة في ذلك (')ومع ذلــــ من العدل أن يعوض المتعاقد .

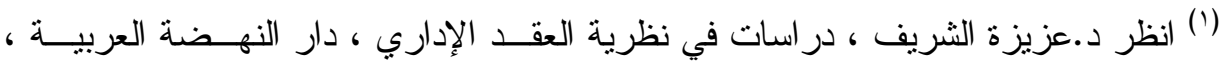
1911 ، ص. (19 ، ، وكذلك أنظر د. مازن للو راضي ، دور الثروط الاستثنائية في تميز

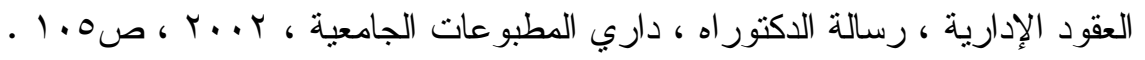




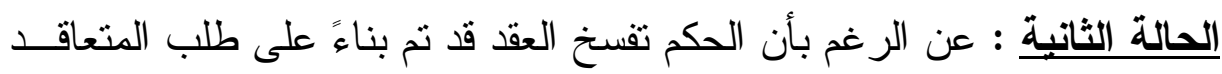

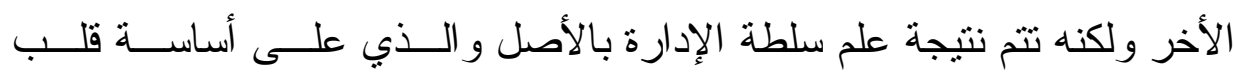
اقتصاديات العقد رأساً على عقب حتى أصبح فيه تتفيذ ما تبقى من شروط وبنود

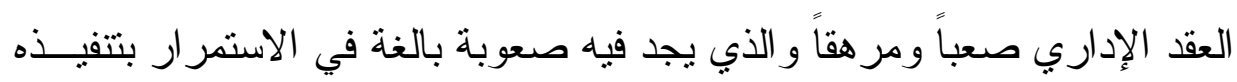
مما مدابه إلى طلب فسخ العقد ، وما يؤدي إليه ذلك في حرمانه مما كان يأمسلـ

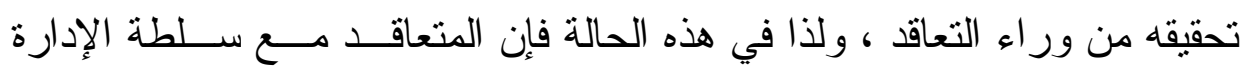

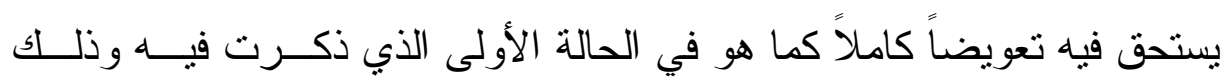

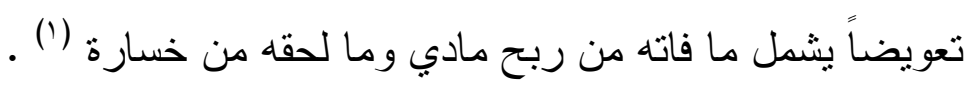
مما لاشك فيه أن المتعاقد المناقص مع الجهة الإدارية كان فرداً أو شركة

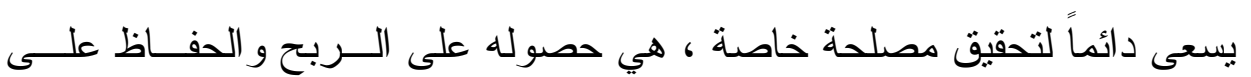
سمعته ومكاتبة التاجر و الأسو اق أو المقاول إنشائي له وزنة من حيث إمكانياتــهـ المالية و الإدارية و الفنية ، و التي صنفت شركته على هذا الأساس(؟) . فإذا كان للجهة الإدارية حقوق منرتبة على العقد الإداري و أيسـضاً فـسخ

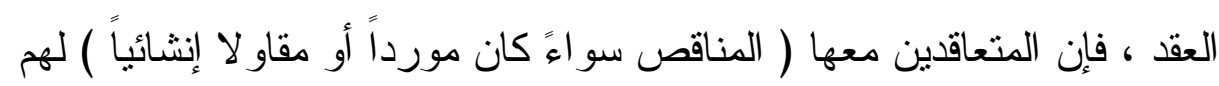

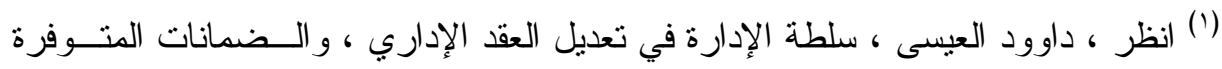

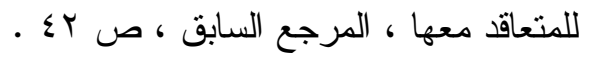

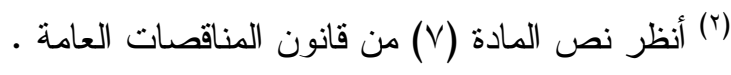

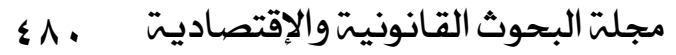




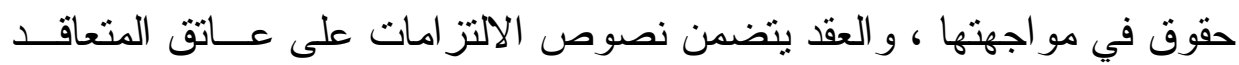
و التي تتمنل في تتفيذ كافة الالتز امات المنصوص عليها في العقد ويتــين علـى المناقص القيام بتتفيذ الالتز امات بنفسه ، فلا يجوز التتازل عنها إلـى غيــره (') و إلا تعرض للعقوبات و الجز اءات المنــصوص عليهــا فــي الــشروط العامــة و الخاصة في بنود العقد أو بموجب الثروط الحقوقية وفقاً للمادة با - 1 مسن هذه الثروط و النزامات المتعاقدين في حالات الإفلاس أو موته (؟) فحق المتعاقد في الحصول على الحقوق المالية كاملة ودون أي نو اقص تذكر و الدذكورة فـي

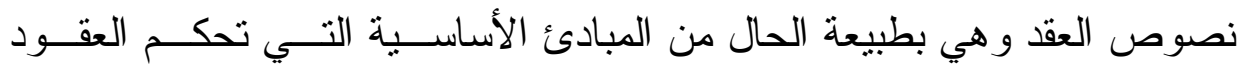

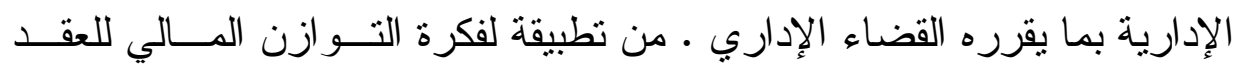
الإداري ، هذا وسوف نناقش في بحثنا هذه الحقوق منها الحق في الحصول على الكقابل المالي للعقد ، و الحق في اقتضـاء التعويض و الحق في ضـــمان التـــوازن

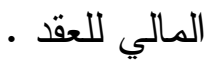

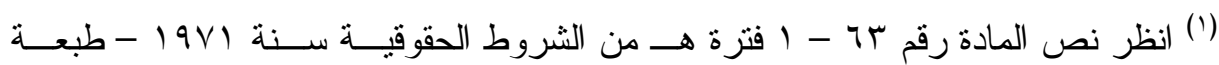

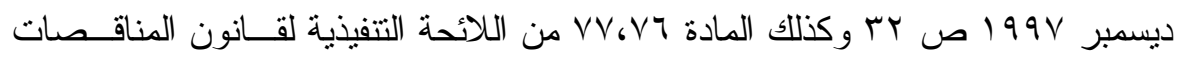

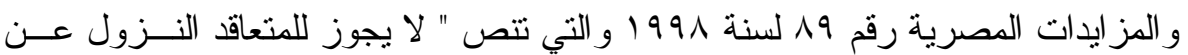

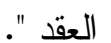

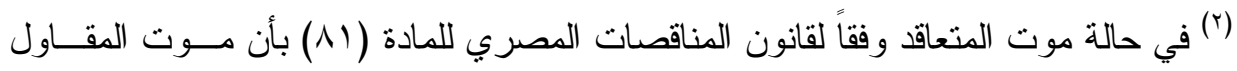

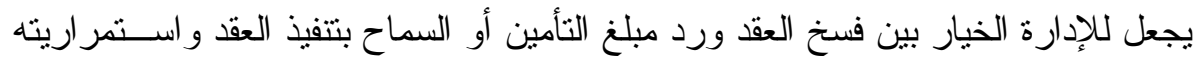
بشرط نعيين وكيل للورثة نو افق علية الإدارة . 


\section{إخلال سلطة الإدارة بأحل بنود وشروط العقد ( الأعذار ):}

La mise en demeure préa label:

يعتبر فسخ العقد الإداري من قبل سلطة الإدارة كأصل عام امر اً نترخص فيه جهة الإدارة وحدها ضماناً يحسن سير المرفق العام أو لتحقيــق المـصلحة العامة وليس للمتعاقد معها إلا حق المطالبة بالتعويض إن كـــان لـــه مقتــى ، ويتسنى على ذللك إنه لبس للمنعاقد مع الإدارة أن يفسخ العقد المبرم معها بقــــار منه إذا ما وجدت مبررات الفسخ ، بل يتعين عليه أن يلجأ إلى القضاء للحصول

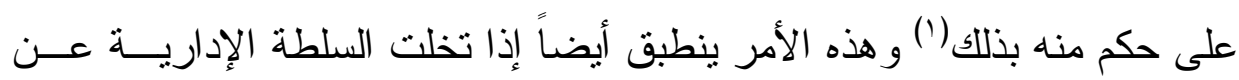

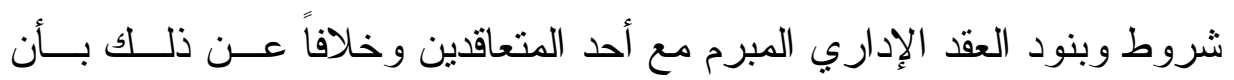
استقضت العقد وتم الفسخ بإر ادتها المنفردة وبوجود نص و اضـــح وصــريح إذا اقدمت السلطة الإدارية بفسخ العقد في المقابل أن يعوض الطرف الثاني في العقد

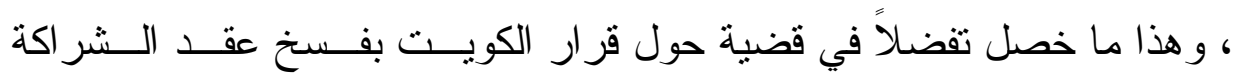
لداوكيميكال (الكيماويات البترولية الأمريكية) و أخرى عام ^ .. r و الذي فسخته الحكومة الكويتية بعد شهر من توضيحة تحت ضغوط نيابية و اعلاميــة وقــر ار

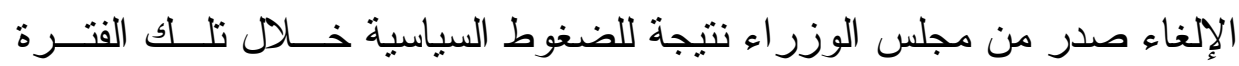

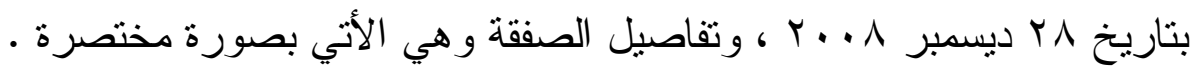


اتجهت مؤسسة البترول لشر اء مصانع داو لأنها تتو افق مع اســتر اتيجية

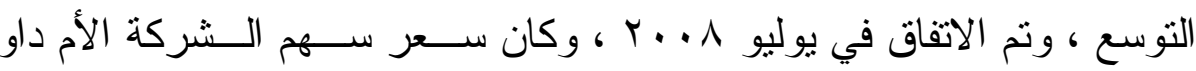

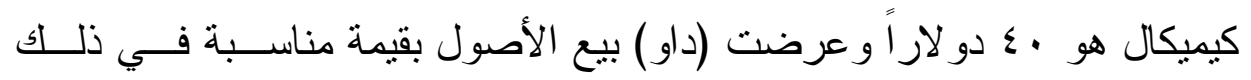
الوقت ، لكن قيمة الأصول بدأت في النزول، و عرضت (داو ) الكويـــت خـصـم

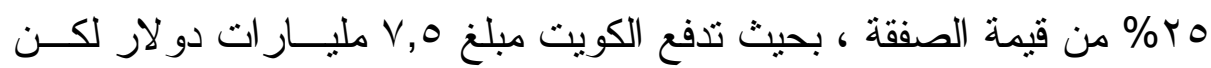
المسؤولين قررو ا عدم تتفيذ الصفقة في كل الأحوال في ديسمبر ^ ... .

\section{• إنهيحار الصفقة :}

بدأت الأسو اق العالمية بالانهيار وتأثرت اســهم شــركات البتروكيماويــات

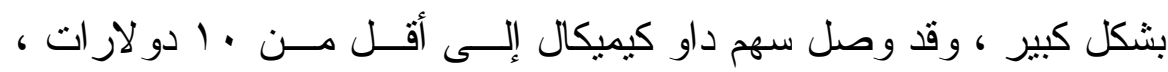
وقررت وقف توزيع أرباح المساهمين لأول مرة في تاريخها منذ ... في يناير 9 . . ، ، وفق صفقة ممانلة ، اختارت ابولو للمساهمات الخاصــة بالخروج من صفقة هيكسيوم من دون دفع الثرط الجزائي المقـدر بمليــار

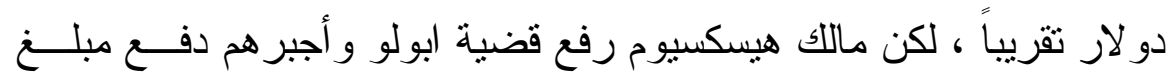
الثرط الجز ائي و التكاليف القانونية ، اختارت حكومة الكويت إنهاء الصفقة

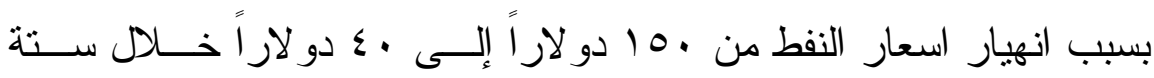

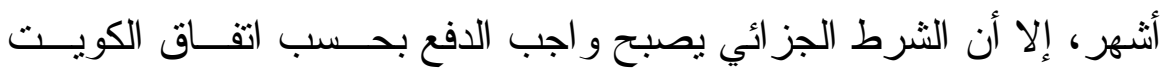

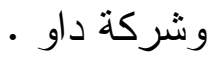


الثرط الجز ائي مرتفع بالمقارنة مع الـصفقات الـشبيهة ، قيمـة الــشرط

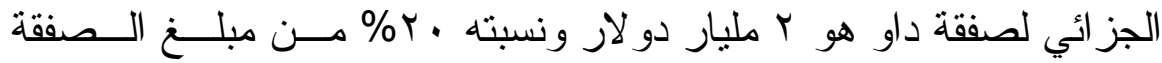

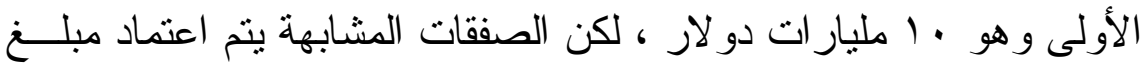
لا يزيد . .0 مليون دو لار ونسبة ه\% من إجمالي الصفقة .

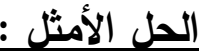

بعد الحكم بموجب القرار الصادر من غرفة التحكيم الدولية في لندن ضــــ

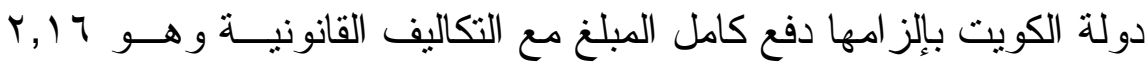
مليار دولار ، تتغير الخيار ات المتاحة للكويت ، تسنطيع الدولة المفاوضــة

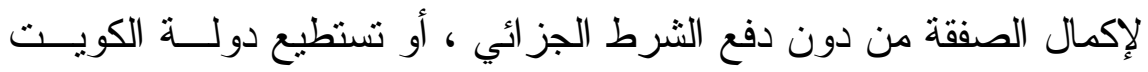
اختيار رفع الضر ائب ايكويت بحيث تسترد جـز ءا مــن تكــاليف الــشرط الجز ائي عبر الضرائب، وقد استرد سهم داو عافيته ويتداول الآن حول ·r دو لار اللسهم الو احد، و ارتقع سعر النفط الكويتي ليصل إلـى • ب ا دو لار ا

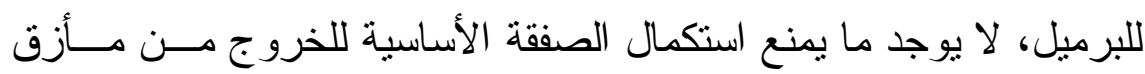

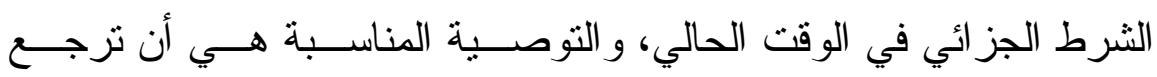
مؤسسة البترول وشركة داو إلى طاولة المفاوضات لتتفيذ الـصفقة سـعر مناسب للطرفين و هو V,0 مليار ات دولار و الجدير بالذكر هنا بــأن هنــاك حكم الاستئناف قد ينقة التعويض بسبب أمور سيادية لدولة الكويت. 


\section{الخاتمة والاستنتاجات}

لقد استعرضنا في هذه الدر اسة في بحثنا هذا جانبا مهما من جو انب وجود سلطة الإدارة في تعديل العقد الإداري بإر ادتها المنفردة ســـواء إذا ورد الـــص لــ

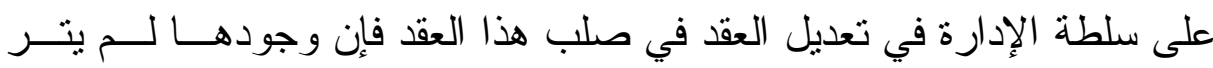
إعر اض من قبل المتعاقد الآخر لأن سلطة الإدارة تستتد فـــي ممارســتها علـى النصوص الواردة في العقد ولها الحق في ذلم ضمن قانون العام، ولكن في حالة وجود نز اع فعلى القاضي أن بطبقه كما يفعل بالنسبة لنصوص ودفاتر شــروط العقد، و لا يكاد القانون الخاص يختلف عن القانون العام في هـــا المجــال لأن وروده في العقد النص على حق الإدارة في تعديل العقد.

و هل يجوز في هذه الحالة للإدارة ان تجري أي تعديل تتطلبه المــصلحة العامة بالرغم عن عدم نص العقد عليه؟ منل هذا الوجود وفي مقابل ذلك تـــوفير الضمانات للمتعاقد مع الإدارة وتطبيق مبدأ التوازن المالي للعقد باعتباره عمـلاً مشرو عاً ولا تتتاقض مع مشروعية عمل الإدارة. من طبيعة العقد الإداري أن بقيم بقدر الإمكان توازنا بين الأعبــاء التــي يتحملها المتعاقد مع الإدارة وبين المز ايا التي ينتفع بها، على اعتبــار أن العقــــ ينظر إليه كوحدة من مقتضاها قيام تلازم بين مصالح الطرفين المتعاقدين، فــإذا ما أدى تدخل الإدارة إلى الاخلال بهذا التوازن كما حدد وقت التعاقـد، وجــب 
إعادة التو ازن المالي للعقد إلى ما كان عليه، وتجرى دفاتز الثروط على الـــص على هذا الحق ولكن المسلم به قضاءا أن هذا الحـق قـــائم باســتمر ار بالنـــبة للمتعاقد حتى إذا لم يكن قد نص عليه صر احة.

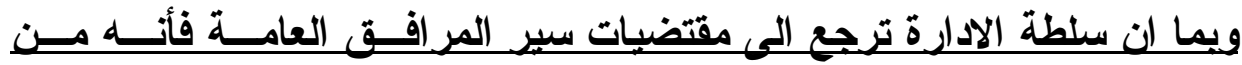
الضروي ان تتوفز ضو ابط معينه الاستعمال هذه السلطات الخاصــة لتعـديل العقد الإداري بالإر ادة، المنفردة للإدارة وهي على الوحه التالي:

أ- ان تكون هنالك ظروف( اسباب مختلفة) قد استجدت بعد ابر ام العقد الاداري تبرر أو تسوغ هذا التعديل حتى وان كانت تللك الظروف تعود الــى خطــــأ الادارة في تقدير اتها و على هذا الاساس لا يجوز للادارة ان تقوم بتعـديل العقد الاداري بار ادتها المنفردة ودون ان تكون هنالك اسباب معينة تــدعو الى هذا التعديل ومما لاثثك فية ان السبب كما لاحظنا كان المحــرك الاول لقيام الادارة بممارسة سلطة اصدار الاعمال القانونيــة المختلفــة (القــــار الاداري، العقد الاداري) وعندما تقوم الادارة بهذه السلطة أي سلطة التعديل

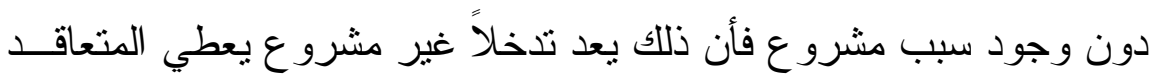
معها الطعن بهذا الاجر اء امام القضاء كما له طلب التعويض عن الاضر ار

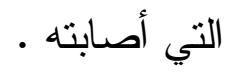


ب- يجب على الادارة ان تحترم في هذا التعديل القو اعد العامة للمشروعية من حيث الاختصاص و الثكل أي يجب ان يصدر قرار التعـديل مــن الجهــة الادارية المختصة طبقاً لما ينظمه القانون كما يجب ان يتجسد هذا التـدخل بالصيغة الثكلية التي رسمها القانون للتعبير الارادي ـال ج- ان تثقيد الادارة بالتعديلات بأن لا تتجاوز حدا معينا أي ان لا تجعل هـــه. التعديلات وكأن المتعاقد امام عقد اداري جديد أبي انــهـ علــى الادارة ان تقدر الامكانبات المالية والفنية للمتعاقد معها وبدون ذلك فأن الادارة لا تجد مستقبلا من يتعاقد معها الامر الذي قد يكلفها الكثير من التكــاليف الماليــة على حساب المصلحة العامة .

د- يجب ان لا تمس هذه التعديلات حق المتعاقد في طلب التعـــيض كمقابــل لسلطة الادارة وذلك لانه في بعض الاحيان قد يكون ســبب اقـــام الادارة

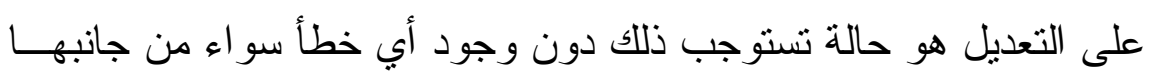
او من المتعاقد كما سنبين ذلك . ال

و هكذا نصل إلى نهاية هذا الاستعر اض الذي أعطى على قدر ما سمح به المقام بسلطة الإدارة في مو اجهة المتعاقد معهاوحقوق هذا الأخير تجـــاه ذلــــك،

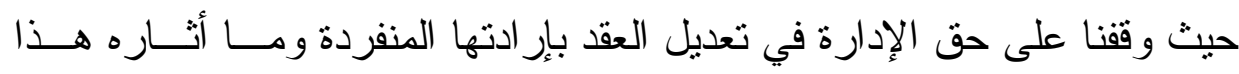

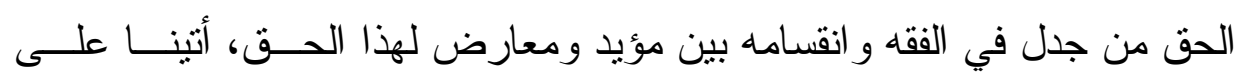


موقف القضاء في هذا الخصوص، كما وقفنا على حدود هذا الحق من حيث مداه و النتائج المتزنبة عليه و الأساس الذي يقوم عليه.

كما وقفنا على حقوق المتعاقد مع الإدارة في مقابل ما تتمتع به الإدارة في

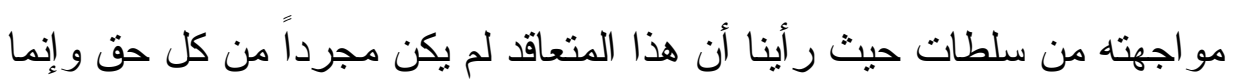
يتمتع بحقوق معترف بها له، لعل أهمها حقه في التعويض الكامـل إذا تــوفرت

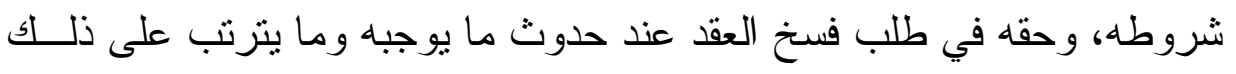

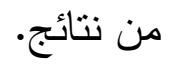
تم البحث بحمد الله تعالى 


\section{هراجع البحث وهصادرها}

\section{أولاً: المراجع العربية}

ا ـ د. ابر اهيم الدسوقي أبو الليل: المسؤولية الإثراء دون سبب ، مؤسسة دار

$$
\text { الكتب القاهرة ، أع } 199
$$

r- - دـ ابر اهيم الفياض: العقود الإدارية ، النظرية العامــة وتطبيقاتهـــا فـي

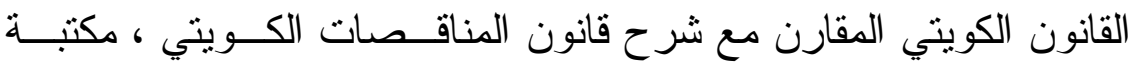

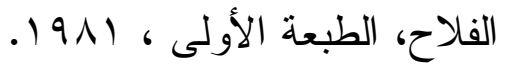

بــ د. أحمد صبحي العطار : جر ائم الإعتداء على المصلحة العامة ، جــر ائم

العدوان على الإدارة العامة دار الطباعة الحديثة ، القاهرة ، 99 ـ

عـ ـ د. أحمد عاثتور : الإدارة العامــة ، دار النهــضة العربيـــة ، بيـروت ،

ــ د. أحمد عثمان عباد : مظاهر السلطة العامـــة والعقــود الإداريـــة ، دار

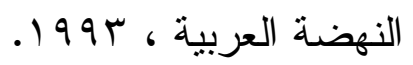

7ـ - د. أحمد رفعت خفاجي: جرائم الرشوة في التشريع المــصري و القــانون

$$
\text { المقارن ، دار قباء للطباعة و النشر ، القاهرة } 999
$$

V- د. أنور أحمد رسلان: القانون الإداري ، دار النهضة العربية ، ع99

$$
\text { مجلت البحوث القانونيت والإقتصاديت } 9 \text { ـ }
$$




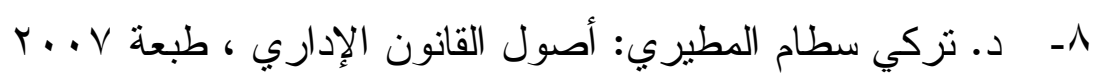

9- د. ثروت بدوي: القانون الإداري ، I9V1.

• ا ـ د. ثروت بدوي: النظرية العامة في العقود الإدارية ، دار النهضة العربية

ال إبر جاد نصار : الوجيز في العقود الإداريــة ، دار النهــضة العربيــة

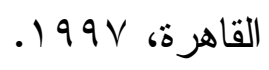

ז ا ـ د. جابر جاد نصـار : المناقصات العامة ، در اسة مقارنـــة فــي القــانون المصري و الفرنسي و اليونستر ال ، الطبعة الثانية ، دار النهضة العربيــة

$$
r \cdot r
$$

سا ــ د. حسن درويش: النظرية العامة في العقــد الإداري ، الجــزء التــاني .1901

ع ا ـ د. حسن محمد هند ، د. محمد حسن علي حسن: الجديد فـي المـشكلات العملية لقانون المناقصات و المز ايدات ، دار الكتـبـ القانونبــة ، مــصر

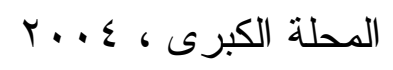

10 ـ د. حسن محمد عو اضية: المبادئ الأساسية للقــانون الإداري ، دراســة

مقارنة المؤسسة الجامعية للار اسات و النشر و التوزيع ، بيروت 99 ل .

مجلتة البحوث القانونيت والإقتصاديت 
17 ـ أ. حليمة بلال عبد الله ، د. مصطفى عبد الجو اد: المدخل لدراسة القانون،

$$
\text { مكتبة دار البيان للطباعة و النشر ، الكويت . . . ب. }
$$

IV I I د. خلف جبوري : النظام القانوني للمناقصات العامة،

11 اـ د. سعيد النجار : نحو إستر اتيجية قوميــة للإصــلاح الإقتــصادي ، دار

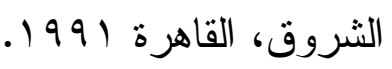

9 1 اـ د. سليمان الطماوي: الأسس العامة للعقود الإدارية ، دراسة مقارنة ، دار

$$
\text { الفكر العربي ، القاهرة ، . 19V1. }
$$

• †- د. صلاح الدين فوزي: قانون المناقصات و المز ايدات المصري رقـم 19 لسنة 1991 ، المشاكل العملية و الحلول القانونية ، القاهرة ، .... ؟.

آـ- د. عبد العزيز خليفة: الأسس العامة للعقود الإدارية ، دار الكتب القانونية

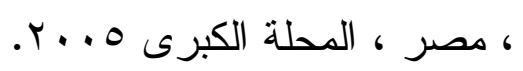

r r- د. عادل مصطفى بسيوني: التشريع الاسلامي و النظم القانونية الوضعية ،

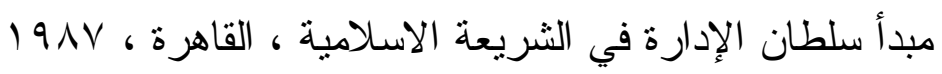
س r- د. عثمان خليل عثمان: في نظرية المر افق العامة ، القاهرة 1901. צ ז- د. عبد الحكيم أحمد عثمان: المناقصات و أحكامها في الفقه الاسلامي، دار الجامعة الجريدة للنشر، الاسكندرية ، . . . ب. 
هY- د. عبد السر اج : شرح قانون العقوبات الإقتصادي ، منـشور ات جامعــة دمشق،

צr- د. عبد الفتاح عبد الباقي: نظرية العقد ، الكويت ، IVVV

Y V د. د. عبد الفتاح عبد الباقي: مصادر الإلتز ام في قانون التجــارة الكـــيتي ، نظرية العقد، الكويت.

^ץ- عبد الفتاح حسن: مبادئ القانوني الإداري الكويتي، دار النهضية العربيــة،

$$
\text { بيروت }
$$

9. - د. عبد الفتاح صبري أبو الليل: أساليب التعاقد الإداري، ـ991.

•ـــ د. عزيزة الثريف: القانون الإداري ، أساليب الإدارة العامة ومـصنوعها

لمبدأ سيادة القانون ، الجزء الأول ، مؤسسة دار الكتب للطباعــة و أثــره

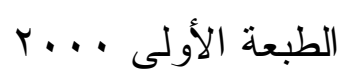

اسب- د. عمر حلمي: طبيعة اختصاص القضاء الإداري بمنازعــات العقـود

$$
\text { الإدارية ، دار النهضة العربية ، ع9 199. }
$$

r r- دي بايير : العقود الإدارية ، طبعة س1911.

بسـ- د. رضوان السيد ر اثد: الإجبار على التعاقد ، رسالة دكتور اه ، جامعــة

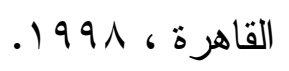

$$
\text { مجلتّ البحوث القانونيتوالإقتصاديت و ؛ }
$$


ع آــ ماجد راغــب الحلــو: القــانون الإداري، دار المطبوعــات الجامعيــة،

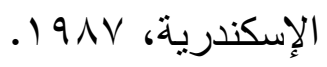

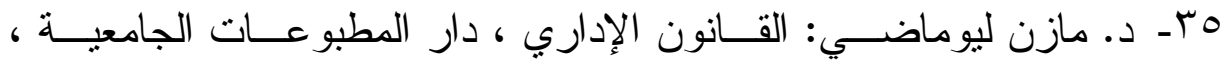

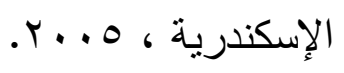

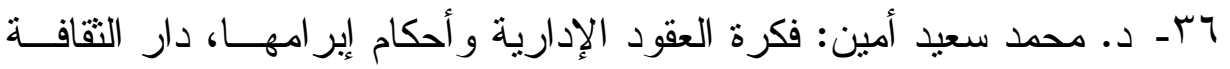

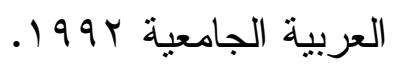

V Yـ د. دجدي متولي: التعليق على قانون نتظيم المناقصات و المز ايدات رقـم

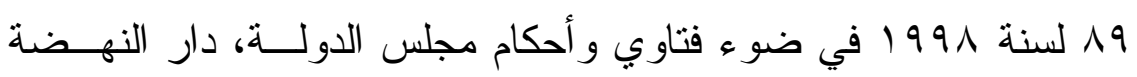

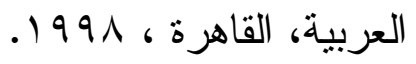

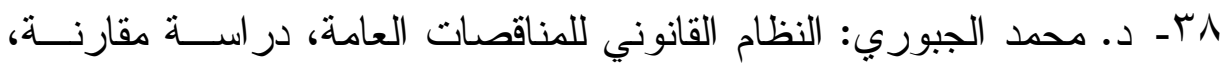

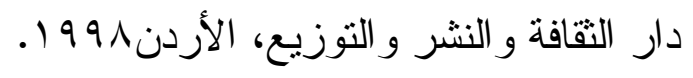

وبــ د. محمد أنور حمادة: قو اعد و إجر اءات تتظيم المناقـــات و المز ايــدات

$$
\text { و العقود الإدارية ، دار الفكر الجامعي، الإسكندرية، ب . . . }
$$

• ــ د. مصطفى عبد المقصود سليم : معيــار العقــد الاداري وأثــره علـى

$$
\text { اختصاص مجلس الدولة ، دار العربية، } 990 \text { 1. }
$$


اءــ د. مهند مختار نوح: الإيجاب و القبول في العقد الإداري ، در اسة مقارنة،

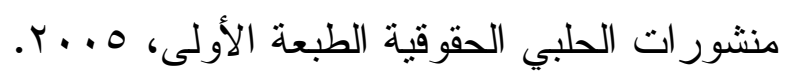

ץ ـ ـ د. محمود محمد صبره: نرجمة العقود الإدارية ، دار الكتب القانونيــة ،

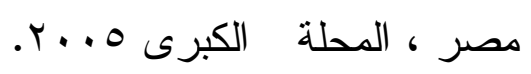

كـــ د. محمد ماهر ابو العينين: قو انين المز ايــــات و المناقـــات ، و العقــود

$$
\text { الإدارية. }
$$

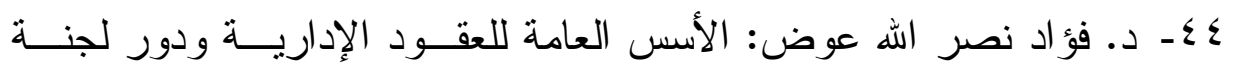

المناقصات المركزية في نطبيق أحكام قانون المناقصات العامة الكويتي ،

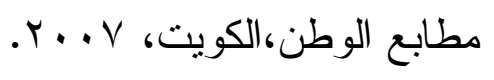

0ـ ــ د. موريس صادق: قانون تتظيم المناقصات و المز ايـــات ، دار محمــود

$$
\text { للنشر و التوزيع ، القاهرة، 1999. }
$$

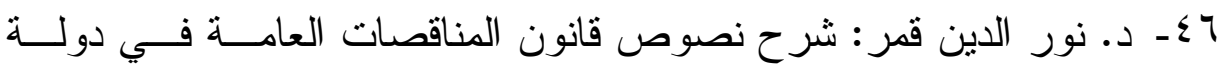

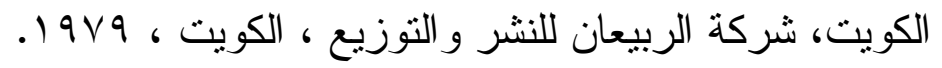




\section{ثانيًا: المراجع الأجنبية (الإنبليزية والفرنسية)}

1- Al ain Barre: Economie et institutions financie're, tom- I ed II, Dalloz, Paris- 1966.

2- Andrede Laubadee': Traite Theorique et Pratique contracts Administratif, Tome primier, Paris, 1959.

3- Benoit, F.P: Le Droit Administratif francais Dalloz, Paris, 1968.

4- Brechon-moulenes,ch : Droit des marche'e Public, TL. Montieur, Paris, 1999.

5- Debasch. Ch. Institutions et Droit Administratif, Dalloz, P.U.F. Paris, ed3, 1992.

6- Chapus. R.: Droit Administratif, TL, paris, 1995.

7- Flamme m. : Traite' Theorique et pratique des marche'es Publics, Bruxelles, 1969.

8- Ghon, JP. : Delite De favoritism, A.S.D.A. Paris, 1994.

9- Guibal, m. : Me'mento des marche's Publics, le meniteur, Paris, 1998.

مجلتّ البحوث القانونيت والإقتصاديت 9 ؛ 
10- Ghestin, J.: Norion de contract, D, 1990.

11- Jeze. G.: Les principles ge'ne'raux de Droit, Administratif, Paris, 1939.

12- Laso, E.S. : Traite' de Droit Administratif, centre francais de compare'e, Paris, 1964.

13- Le vermeur, L. : LaLibe'rte' contractuelle en Droit Prive', A.J.D.A. Paris, 1998.

14- Le maitre, M.F. : Les crite'res de choix des offers Dans les marche's Publics, R.M.P. No. 265

15- P.D.V. March:The art of Tendring, England, Gower, Technical press L. 1987.

16- Sief Askar. A. : L'appel D'offres en france et syrie, universite Montpellier, 1998.

17- Sink condo, M.H. : Lanotion de contract Administratif act unilateral ou contract civil de L'Administratif N R.T.D.C. 1988.

18- Rivero, J. : Droit Administratif, Dalloz, paris, 1980.

19- Waline m. : Droit Administratif, ge'me-e'd- Paris, 1963.

مجلتة البحوث القانونيت والإقتصاديت 9 ؛ 


\section{ثالثًاً : الدوريات - هقالات.}

1- الثروط الحقوقية رقم (11-19) الثروط العامة - سنة 19VI - طبعة ديسمبر I9VI ا ، وزارة الأشغال العامة مطبعة الحكومة - وز ارة الإعلام. r- قانون المناقصات العامة رقم (rV) لسنة ع 197 ـ

r- لجنة المناقصات المركزية - القوانين الخاصة بشأن تتظيم المناقصات

$$
\text { و المز ايدات - دولة قطر - وز ارة المالية و البترول - ع } 99 \text { ـ. }
$$

ع- مجموعة النشريعات الكويتية - الجزء الخامس - الطبعة الثالثة ـ مجلس

$$
\text { الوزر اء - - اد دار الفتوى و التشريع. }
$$

0ـ المنظمة لأعمال الجهاز الإداري بالدولة، مجموعة التشريعات الكويتية ، الجزء الر ابع، الطبعة الثالثة - 90 19، إدارة الفتوى و التشريع.

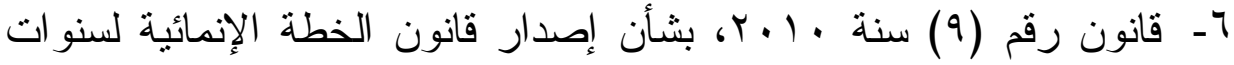
• • • (1) • •

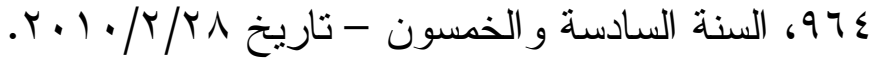

V- د. احمد منير نجار ، دور الإنفاق العام في تحقيق الإستقرار الإقتصادي في حالة دولة الكويت ، مجلة دراسات الخليج و الجزيرة العربية. العدد الثاني و التسعون، السنة (ع r) يناير 999 ( 199 
ᄉـ د. فؤ اد العطار ، وسائل تعاقد الإدارة ، نظرية المناقصة و الممارسة ، مجلة

$$
\text { الدولة ، مجلد الخامس و السادس - القضاء الإداري. }
$$

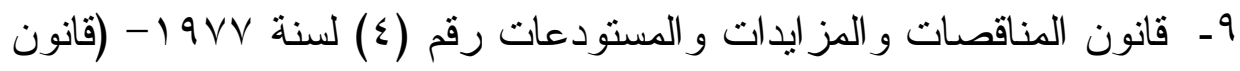

$$
\text { المناقصات لدولة الإمار ات العربية المتحدة - ابوظبي) }
$$

• ـ ـقانون المناقصات لسلطة عمان = مجلس المناقصات لسلطنة عمان.

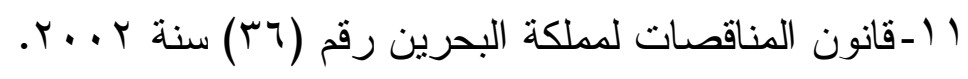

ץ ا-د. حمد منصور ، د. نجوى بكر، موسوعة المناقصات، دراسة عملية تقيلية لنصوص قانون المناقصات العامة و النصوص المرتبطة في ضوء فتاوي، إدارة الفتوى والتشريع وأحكام القضاء الكويتي، شركة مشرف

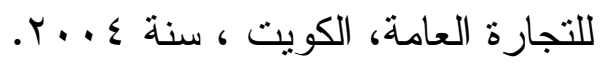

